\title{
Paleozoic and Precambrian Rocks of Alaska and Their Role in its Structural Evolution
}

By MICHAEL CHURKIN, JR.

GEOLOGICAL SURVEY PROFESIONAL PAPER 740

Stratigraphy and correlation of Paleozoic and Precambrian rocks of Alaska, tectonic framework of sedimentation, and their bearing on sea-floor spreading and continental drift in the Arctic 


\title{
UNITED STATES DEPARTMENT OF THE INTERIOR
}

ROGERS C. B. MORTON, Secretary

\section{GEOLOGICAL SURVEY}

\author{
V. E. McKelvey, Director
}

Library of Congress catalog-card No. 72-600193

For sale by the Superintendent of Documents, U.S. Government Printing Office, Washington, D.C. 20402 Price: paper cover-90 cents domestic postpaid, or 65 cents GPO Bookstore Stock Number 2401-00272 


\section{CONTENTS}

Abstract
Introduction
Acknowledgments
Precambrian rocks
Unmetamorphosed rocks
Older schists of uncertain age
Lower Paleozoic cycle of sedimentation
Cambrian rocks
Ordovician rocks
Silurian rocks
Lower and Middle Devonian rocks
Upper Paleozoic cycle of sedimentation
Upper Devonian rocks
Carboniferous rocks
Permian rocks - -

Page

1

Interpretation of stratigraphic data-Tectonic framework of sedimentation-Continued

Lower Paleozoic rocks-Continued

Yukon shelf and Richardson basin _.______ 37

Ancestral Brooks geosyncline

Upper Paleozoic rocks ___ 39

Cordilleran geosyncline _._. 39

Yukon shelf

Brooks basin and related successor basins _-_-_ 39

Mesozoic and Cenozoic tectonic events affecting Paleozoic rocks

Major structural features of Paleozoic rocks _-___-_ 42

Foldbelts of Alaska and their extensions into Canada and Siberia

Longitudinal faults and topographic trenches -- 46

Correlation of the Paleozoic rocks around the edges of the Arctic and northerm Pacific Basins and sea-floor spreading in the Arctic

References cited 56

Index

\section{ILLUSTRATIONS}

Figure 1. Tectonic framework of early Paleozoic (Cambrian to Middle Devonian)

FIGURE 1. Tectonic framework of early Paleozoic (Cambrian to Middle Devonian)
sedimentation

Page

2. Precambrian rocks and metamorphic complexes that may include Precambrian strata

3. Columnar sections of late Precambrian and Cambrian rocks in eastcentral Alaska _-... 8

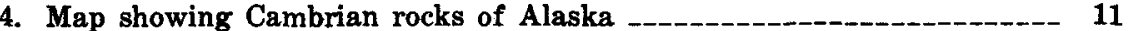

5. Map showing Ordovician rocks of Alaska

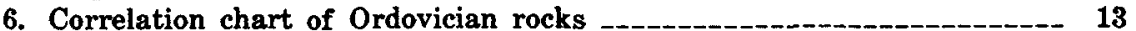

7. Map showing Silurian rocks of Alaska

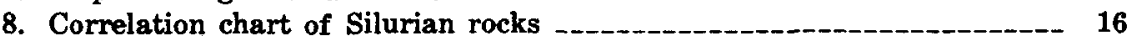

9. Index map of southeastern Alaska

10. Correlation chart of major rock types of Paleozoic age in southeastern Alaska showing rapid lateral changes in stratigraphy due to facies changes and, in some cases, structural dislocations --..-- 20

11. Map showing Devonian rocks. Excludes coarse terrigenous rocks of Late Devonian and Mississippian age (Nation River, Kanayut, and Kekiktuk Formations)

12. Correlation chart of Devonian rocks _.

13. Map showing Devonian coarse terrigenous rocks. Includes Mississippian Kekiktuk Conglomerate _.

14. Map showing Carboniferous rocks of Alaska _.___________ 28

15. Correlation chart of Carboniferous and Permian rocks _._. 30 
Figure 16. Map showing Permian rocks of Alaska

17. Tectonic framework of Carboniferous and Permian sedimentation 32

18. Late Mesozoic and Tertiary tectonic features -

of the Arctic Ocean

20. Major structural features of the northern circumpacific and adjacent parts of the Arctic -

21. Boundaries of the major crustal plates in the Northern Hemisphere -- 48

22. Correlation diagrams of the Paleozoic and Precambrian stratigraphy around the Canada Basin and central parts of Alaska and Northeast U.S.S.R.

23. Geologic map and sections of the eastern part of the Chukotsk Peninsula, Northeast U.S.S.R.

24. Major tectonic features of the Arctic 


\title{
PALEOZOIC AND PRECAMBRIAN ROCKS OF ALASKA AND THEIR ROLE IN ITS STRUCTURAL EVOLUTION
}

\author{
By Michael Churkin, Jr.
}

\section{ABSTRACT}

Acknowledging that there are large gaps in the knowledge of the geology of Alaska, the following threefold subdivision of Alaska into Paleozoic tectonic elements is proposed: (1) Southern Alaska-the Alaska Range and farther south -is the northern end of the Paleozoic Cordilleran geosyncline that rims the eastern Pacific. (2) Northern Alaskathe northeastern Brooks Range and the Arctic Coastal Plain-is underlain by a pre-Late Devonian foldbelt that may continue around the rim of the Canada Basin into the Franklinian geosyncline of the Canadian Arctic Islands on the east and extend west along the outer margins of the Chukchi and East Siberian Seas. (3) East-central Alaska, with a thinner, mainly carbonate rock section, seems to be a western extension of the Yukon shelf that separates the circumaretic geosynclinal trend from the Cordilleran geosyncline along the Pacific margin of southern Alaska.

In southeastern Alaska, deposition of graywacke, polymictic conglomerate, and argillaceous rocks interbedded with pillow basalts, breccias, and tuffs prevailed throughout most of the Paleozoic. One exception, a widespread red-bed conglomerate and crossbedded sandstone sequence of Late Silurian(?) and Early Devonian age marks a regional break in sedimentation. Local thick limestones made up of fragmented fossils indicate reef and shallow-water shell-bank development. Very abrupt facies changes reflect rugged bottom relief largely controlled by volcanic activity. The high proportion of volcanic rocks and some plutonic intrusions of early Paleozoic age that have closely associated thick lenses of synorogenic boulder conglomerates imply high tectonic mobility. Isolated exposures of similar Paleozoic rocks in the Wrangell Mountains, Alaska Range, and the Alaska Peninsula suggest that the coarse detrital-volcanic belt of southeastern Alaska rims the northern Pacific Basin and may continue west along the edge of the Bering Shelf sea into the Koryak Upland of Northeast U.S.S.R., where similar sequences occur.

In northern Alaska, a deformed belt of pre-Late Devonian strata containing interlayered volcanic rocks occurs in the northeastern Brooks Range. Farther west, in the Arctic Coastal Plain, boreholes have penetrated steeply dipping, weakly metamorphosed rocks that probably belong to this same foldbelt, thereby suggesting that a largely buried and partly destroyed geosyncline of pre-Late Devonian age, including rocks of Cambrian and Silurian age, lies along the northern edge of Alaska. Thick sections of chert-rich detrital rocks of Late Devonian and, farther north, of Mississippian age lie unconformably on this ancestral Brooks geosyncline and were derived from uplifts within the geosyncline. These clastic deposits, at least in part of nonmarine origin, continue around the edge of the Canada Basin from Alaska east to
Ellesmere Island and west to Wrangell Island. Absolute age determinations indicate that the intrusion of granitic rocks around the margin of the Canada Basin was probably related to the same middle-Paleozoic orogeny that produced the wedge of Upper Devonian and Mississippian clastics. After the orogeny, marine shale and carbonate rocks were again deposited around the edges of the Canada Basin. In the Brooks Range, the base of the Carboniferous section becomes progressively younger northward, and the whole section has more terrigenous detritus in northern parts of the range. This northward transgression, in addition to the fact that the unconformably overlying Permian (in boreholes north of the Brooks Range) is a chert-pebble conglomerate, suggests that in the late Paleozoic a source area existed in the northern Brooks Range and farther north as it had in the Late Devonian.

In east-central Alaska, Cambrian through Devonian time is represented by a thin, but nearly complete, sequence mainly of limestone. Along the Yukon River, which is the south edge of the Yukon shelf, thin graptolitic shale and chert and, in places, Devonian pillow basalt indicate a transitional facies into the Cordilleran geosyncline farther south. In the Late Devonian, thick nonmarine conglomerate and sandstone were apparently derived from uplifts within the nearby Cordilleran geosyncline, starting the upper Paleozoic cycle of higher tectonic activity in the interior parts of Alaska. Carboniferous rocks in east-central Alaska form a thin sequence of interbedded limestone, shale, and chert. Pre-Permian erosion has removed most of the Carboniferous, and the Permian is a thin sequence of conglomerate, sandstone, and limestone.

Nonvolcanic, nearly pure carbonate sections in the Seward Peninsula, in parts of southwestern Alaska and on St. Lawrence Island, especially those representing the lower Paleozoic, suggest that the carbonate shelf type of sedimentation characteristic of east-central Alaska extended into western Alaska. Similar strata on the Chukotsk Peninsula indicate that this belt of mainly carbonate rock continues west across the Bering Strait, thereby linking the geology of Alaska to Asia.

During the Mesozoic and Cenozoic the broad Paleozoic stratigraphic belts of Alaska were deformed into numerous troughs and uplifts. Batholithic intrusions, volcanism, and metamorphism, together with penetrative folding and faulting during the multiple episodes of Mesozoic and Cenozoic orogeny, have largely obscured the Paleozoic and older structures. However, the patterns of basins and uplifts in the Mesozoic and, to a lesser degree, in the Tertiary tend to follow the trend of the Paleozoic stratigraphic belts that form their basement. The Cordilleran foldbelt that had its 
climactic orogeny during the Mesozoic includes most of Alaska and correlates with the Chukotka foldbelt in Northeast U.S.S.R. The younger circumpacific foldbelt of Cenozoic age produced folds and general uplift in Kamchatka and the Koryak Mountains and in the Gulf of Alaska includes a thrust belt. Another, though less obvious, foldbelt of middle Paleozoic age discontinuously rims the southern margin of the Canada Basin. It is deeply eroded and is largely covered by flat-lying Mesozoic and Cenozoic deposits that form the Arctic Coastal Plain.

In evaluating continental drift in the Arctic, there is no direct evidence for large-scale drift between Alaska and Northeast U.S.S.R. Correlations of stratigraphy, paleogeography, structure, igneous activity, metamorphism, ore deposits, and crustal structure between Alaska and easternmost U.S.S.R. indicate that these two continental areas have been connected since the Paleozoic and probably since the Precambrian, and that no. plate boundary passes through the Bering Strait.

Sea-floor spreading that fcrmed the Atlantic Basin seems to have extended across the Eurasia Basin part of the Arctic. Modern sea-floor-spreading tectonics on the Gakkel submarine ridge of the Eurasia Basin continue landward into the Yakutia region of Siberia to produce seismic activity, faulting, and volcanism.

Earlier compressional features of Paleozoic and, especially, Mesozoic age on trend with the Arctic Ocean opening, contrast strongly with these modern tensional movements. Stratigraphic, structural, and petrological features suggest that a fossil plate boundary within Yakutia marks the western boundary of the North American plate. This plate boundary and bends in various large-scale structures in Alaska and Northeast U.S.S.R. may be in part results of compression in this narrow continental segment as the leading edges of the Eurasian and North American plates collided in Early Cretaceous time, perhaps as a consequence of opening of the northern Atlantic.

\section{INTRODUCTION}

Alaska, being a narrow isthmus connecting North America to Eurasia, is a key to understanding the geologic correlations around the northern Pacific, on the one hand, and the geology of the circumarctic areas, on the other. Besides serving as a link between North America and Eurasia, Alaska is important in evaluating the ancient histories of the Arctic and northern Pacific Oceans through a study of its continental margins. Finally, Alaska plays a vital role in testing theories of continental drift and sea-floor spreading in the Arctic.

Although a number of stratigraphic and tectonic summaries of Alaska have been made, these have focused mainly on Mesozoic and Tertiary rocks (Mertie, 1930b; Smith, 1939; Eardley, 1948; Payne, 1955; Gates and Gryc, 1963). Knowledge of Precambrian and Paleozoic rocks in Alaska has substantially increased since Schuchert's first maps covering North
America were published in 1910 . To date, however, there is no regional synthesis of the Precambrian and Paleozoic history of Alaska using the latest data to make modern correlation diagrams, lithofacies maps, and paleotectonic maps useful in interpreting earth history. It is my goal here to summarize the present knowledge of the Precambrian and Paleozoic rocks of Alaska and to interpret their role in its tectonic and structural development.

The first part of the paper summarizes the Precambrian and Paleozoic stratigraphy of Alaska. The second part is an interpretation of the tectonic and structural evolution of Alaska based on the stratigraphic data and on structural and geophysical data. Because of the great variation in the level of our knowledge of the different areas of Alaska, and for the sake of brevity, only the more thoroughly studied stratigraphic successions in each geologic province are discussed and illustrated by columnar sections. A list of the major literature references is given to guide the reader in obtaining details.

Acknowledging that there are big gaps in the present knowledge of the Paleozoic rocks of Alaska, especially in its southwestern and central interior parts, the author proposes a threefold tectonic subdivision of Alaska (fig. 1; see also fig. 17). Apparently, during most of Paleozoic time sedimentation in Alaska was controlled by the Cordilleran geosyncline in its southern part and by several geosynclinal cycles in northern Alaska along the southern edge of the Arctic Basin. In the interior of Alaska the Paleozoic record is less clear, but at least in eastcentral Alaska a western extension of the Yukon shelf seemed to have separated these two geosynclinal trends.

Detailed stratigraphic studies have been made in some areas in conjunction with reconnaissance geologic mapping. In most places where Paleozoic rocks have been mapped, however, their ages and stratigraphic succession are poorly known because of structural complexities and incomplete knowledge of fossils and other tools for correlation. The stratigraphic sequences of east-central Alaska and southeastern Alaska are emphasized because they are among the most thoroughly studied, seem to be the most complete, and are the most familiar to me. It must be noted that the correlations, and consequently the general interpretations offered, are only preliminary. The accelerated program of geological exploration that has started with the discovery of large oil reserves along the Arctic coast of Alaska will provide much-needed subsurface information that could re- 


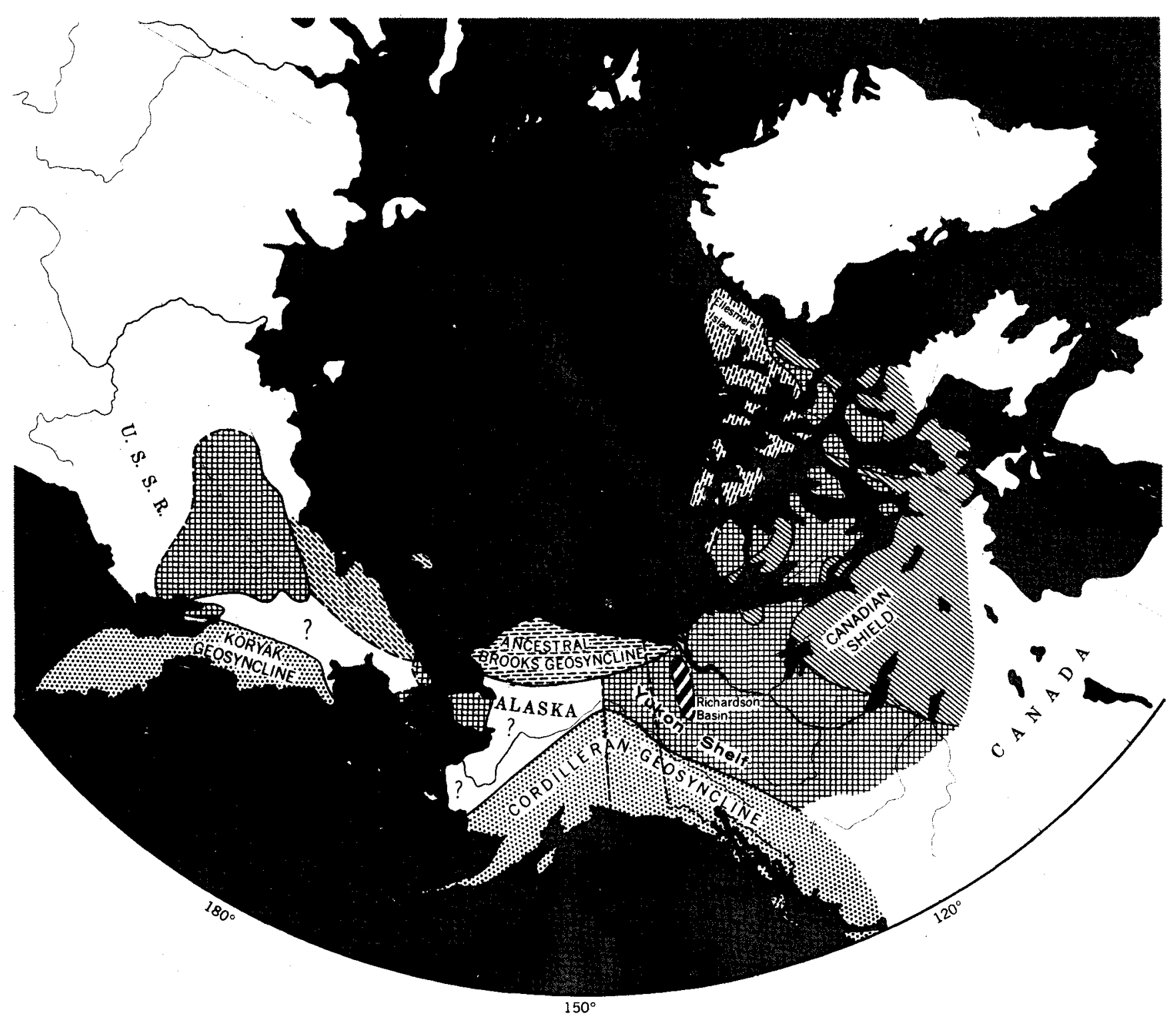

EXPLANATION
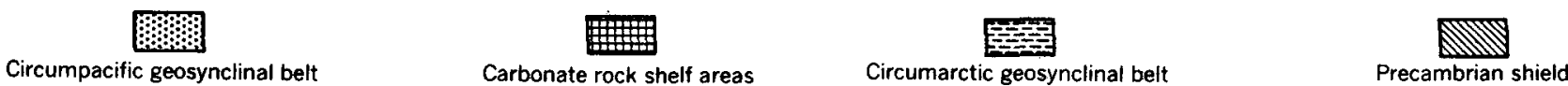

Figure 1.-Tectonic framework of early Paleozoic (Cambrian to Middle Devonian) sedimentation.

sult in major changes in even the broadest tectonic outline.

For a summary of the Paleozoic stratigraphy and tectonic history of Canada adjacent to Alaska, the reader may refer to Gabrielse (1967), Gabrielse and
Wheeler (1961), and Zeigler (1969). For a regional analysis of parts of the Soviet Union adjacent to Alaska, the following references are useful: Belyi, 1964; Bogdanov, 1963, Bogdanov and Tilman, 1964; Egiazarov and others, 1965; Egiazarov, 1969; Gni- 
bidenko, 1969; Krasniy, 1966; Tilman, 1962; and Yanshin, 1966.

\section{ACKNOWLEDGMENTS}

Most of the references to geologic studies that are cited herein are publications of the U.S. Geological Survey-the organization long responsible for systematically exploring and mapping Alaska. Specific recognition is given the following members of the U.S. Geological Survey: E. E. Brabb, for valuable discussions of the stratigraphy and structure of eastcentral Alaska; D. A. Brew, for familiarizing me with the stratigraphy of the Freshwater Bay-Glacier Bay areas; W. P. Brosgé and H. N. Reiser, for much information on the Brooks Range; R. M. Chapman, F. R. Weber, and R. L. Foster, for helicopter reconnaissance and much information on the Livengood district; R. L. Detterman and B. L. Reed, for information on the Alaska Peninsula; G. D. Eberlein, for much of the basic knowledge of the stratigraphy in southeastern Alaska; R. B. Forbes for information on the Birch Creek Schist; J. M. Hoare and W. H. Condon for data concerning southwestern Alaska; E. H. Lathram, for stimulating discussions on the tectonics of northern Alaska; E. M. MacKevett and J. G. Smith for information on the Wrangell Mountains; L. J. P. Muffler, for a tour of the Kuiu Island area; A. T. Ovenshine, for conodont correlations and Silurian and Devonian stratigraphy of the Kosciusco Island area; W. W. Patton, for data concerning the Koyukuk River area and St. Lawrence Island; George Plafker, for discussion of how earth movements in the Gulf of Alaska associated with the 1964 earthquake may relate to the tectonic development of Alaska ; B. L. Reed, for acquainting me with part of the Alaskan Range and for structural information in the northeastern Brooks Range; D. H. Richter, for data on the stratigraphy of the eastern Alaska Range; C. L. Sainsbury, for an excursion and much structural and stratigraphic information on the Seward Peninsula; and to I. L. Tailleur, for information on the structure and stratigraphy of the western Brooks Range.

Special thanks are given to the many paleontologists of the Geological Survey, without whose interest in Alaskan fossils many of the correlations would not have been possible. The "Annotated Bibliography of Alaskan Paleozoic Paleontology" (Dutro, 1956) conveniently summarizes much of their earlier work. More recently, the following paleontologists have been especially helpful in identifying Alaskan Paleozoic fossils: A. K. Armstrong, Jean Berdan, Claire
Carter, Helen Duncan, R. C. Douglass, J. T. Dutro, Jr., R. E. Grant, J. W. Huddle, S. H. Mamay, W. A. Oliver, Jr., A. R. Palmer, R. J. Ross, Jr., R. A. Scott, E. L. Yochelson.

I am especially grateful to the Canadian geologists, J. W. Kerr, J. A. Jeletzky, H. P. Trettin, D. E. Jackson, A. C. Lenz, B. S. Norford, P. A. Ziegler, and E. W. Bamber, and to many Soviet geologists including N. A. Bogdanov, V. F. Belyi, B. Kh. Egiazarov, G. S. Gnibidenko, Yu. A. Kosygin, L. I. Krasniy, Yu. M. Puscharovsky, and A. L. Yanshin for discussion and much information on the geology of neighboring parts of Canada and Siberia. Thanks are due to the U.S. and Soviet Academies of Sciences for sponsoring my visits to the U.S.S.R. in 1967 and 1971 and to the Geological Survey of Canada for arranging exchange visits of L. H. Green, E. W. Bamber, and J. W. Kerr to Alaska.

\section{STRATIGRAPHY \\ PRECAMBRIAN ROCKS}

Until recently, large areas of metamorphic rocks in the central and southern parts of Alaska were considered to be Precambrian (Smith, 1939; Dutro and Payne, 1957). With the realization that younger formations extend into these areas of high metamorphism, many of these metamorphic complexes are now thought to include much younger rocks. For example, radiometric dating has shown that the metamorphism in the Yukon-Tanana Upland, believed to be dominantly Precambrian, is in some part Mesozoic (Wasserberg and others, 1963). One difficulty in determining that any rocks are Precambrian is the lack of fossil control. Only in a small area of eastcentral Alaska are there rocks that can be definitely recognized as Cambrian by their fossil content. These are known to overlie stratigraphically still older rocks-the Tindir Group. As a result, many of the previous Precambrian assignments outside this small área, especially of metamorphic rocks, are somewhat in doubt (fig. 2).

\section{UNMETAMORPHOSED ROCKS}

The term Tindir Group was first applied to a thick sequence of unmetamorphosed sedimentary rocks that conformably underlies fossiliferous Middle Cambrian limestone along the Alaska-Yukon Territory boundary (Cairnes, 1914). Mertie (1933) studied the Tindir in the vicinity of the Yukon River where it is best exposed and subdivided it into seven units.

More recently, part of this area was mapped and studied in greater detail (Brabb and Churkin, 1965; 


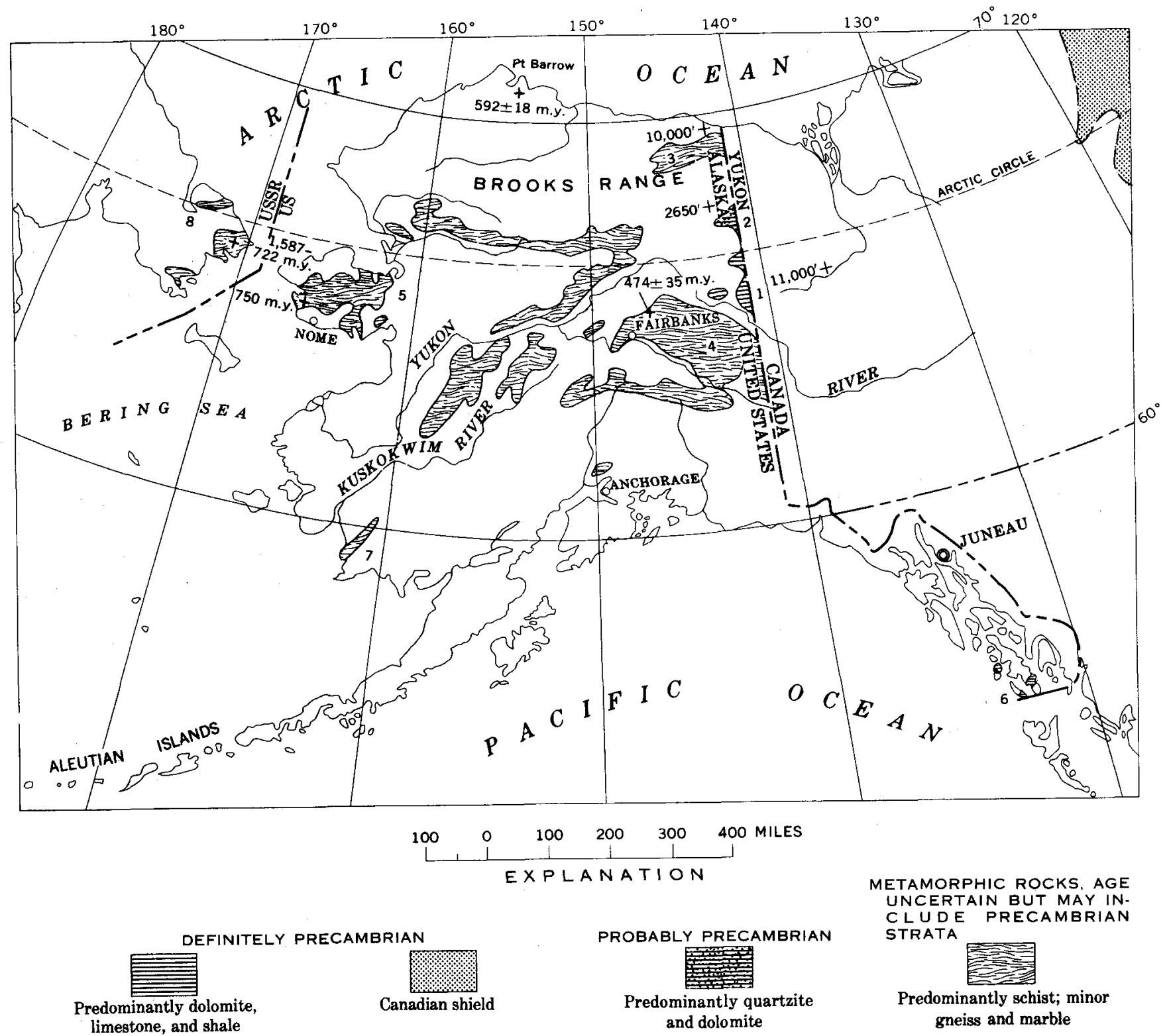

FIGURE 2.-Precambrian rocks and metamorphic sequences that may include Precambrian strata. Rock dates in millions of years $(\mathrm{m.y.})$.

\section{SOURCES OF DATA}

1. Charley River area: Tindir Group (Mertie, 1933; Brabb and Churkin, 1969).

2. Porcupine River: Tindir(?) Group (Kindle, 1908; Brosgé and others, 1966).

3. Eastern Brooks Range:

Neruokpuk Formation (Brosgé and others, 1962; Reiser, 1970).

4. Yukon-Tanana Upland:

Birch Creek Schist (Mertie, 1930a)

$474 \pm 35$ m.y. K/A (Forbes and others, 1968).

5. Seward Peninsula:

Slates in York Mountains and Kigluaik Schist (Moffit,
1913; Sainsbury, 1969a).750-m.y. Rb/Sr whole-rock date on gneiss; $450-$ m.y. $\mathrm{Rb} / \mathrm{Sr}$ whole-rock date on dike (Sainsbury, written commun., 1970).

6. Alexander Archipelago:

Wales Group (Buddington and Chapin, 1929).

7. Lower Kuskokwim region:

Gneiss and schist overlain by unmetamorphosed Devonian limestone (Hoare and Coonrad, 1961).

8. Chukotsk Peninsula:

Gneiss mantled by schist, 1587-722 m.y. K/A (Gnibidenko, 1969).

Argillite in bottom of Simpson well, 592 $\pm 18-m . y . ~ K / A$ wholerock date (M. Lanphere, in Brosgé and Tailleur, 1970). 
1969). The following five map units, totaling more than 11,000 feet, were then established:

Lower Cambrian.

Adams Argillite: Argillite, siltstone, and quartzite; rare limestone lenses and greenstone. Contains archaeocyathids, trilobites, worm (?) burrows, and Oldhamia. $300-600 \mathrm{ft}$ thick.

Funnel Creek Limestone: Massive limestone and dolomite. Nonfossiliferous. $1,000-1,300 \mathrm{ft}$ thick.

Conformable contact.

Precambrian.

Tindir Group:

Limestone member: Dark-gray, thin-bedded, and laminated limestone with slabby and platy partings; interbeds of greenish-gray shale, siltstone, and sandstone; minor sandy limestone, laminated dolomite, calcareous dolomite and chert-carbonate gritstone. 800-1,500 ft thick.

Dolomitic sandstone and shale member: Light-gray, thin- to medium-bedded doloarenite and olive-gray shale; minor gritstone and conglomerate. About $2,500 \mathrm{ft}$ thick.

Basalt and red-bed member: Dark-greenish-gray basalt, commonly amygdaloidal and with pillow structure; minor basaltic tuff. Red and grayishred hematite-rich shale and siliceous iron formation; minor greenish-gray shale, jasper, greenstone-dolomite conglomerate, and vitric tuff and lava, largely replaced by hematite and carbonate. 2,500 ft thick.

Dolomite and shale member: Light- to medium-gray laminated dolomite and grayish-black shale; minor chert, doloarenite, and dolomite-chert gritstone. Has lentil of stromatolite-bearing limestone. Cut by diabase dikes. About 3,000 ft thick.

Shale member: Grayish-black carbonaceous shale; minor interbeds of quartzite, limestone, dolomite, and dolomite conglomerate (possible tillite). Cut by diabase dikes. Base apparently not exposed. A few thousand feet thick.

Diabase dikes, especially abundant in the lower parts of the Tindir, are probably related to the emplacement of the stratigraphically higher lavas.

The rhythmically bedded siliceous iron formation that is associated with the conglomerate of mixed composition and the mafic volcanic rocks in the Tindir Group is probably correlative with similar ironrich beds of the Rapitan Formation (Gabrielse, 1967) in Yukon Territory.

Cairnes $(1914 a$, p. $185-187$; 1914b, p. 56) originally thought that the Tindir Group was either Precambrian or Cambrian. Mertie (1933, p. 392) considered the Tindir as probably entirely Precambrian, but the oldest fossils then known above the Tindir were Middle Cambrian trilobites. More recent work has shown that archaeocyathids of earliest Cambrian age occur 500 feet above the highest unit of the Tindir (Brabb, 1967). Furthermore, Early Cam- brian trilobites and archaeocyathids occur in the Adams Argillite, more than a thousand feet above the top of the Tindir Group. However, no definite discontinuity has been recognized as separating these fossiliferous horizons from the Tindir Group (Brabb, 1967; Palmer, 1968). Thus, the top of the Tindir Group is considered by Brabb (1967) to mark the top of the Precambrian in east-central Alaska.

The only fossils known from the Tindir are wellpreserved stromatolites (laminated algal structures) from lenticular limestone in the dolomite and shale unit of the Tindir some 8,000 feet below the Early Cambrian fossils (Brabb and Churkin, 1969). A preliminary examination of these stromatolites indicates a close similarity to stromatolites in rocks of late middle Riphean age from the Aldan Shield of Siberia (M. A. Semihatov, written commun., 1968).

Lithologically, the Tindir resembles the Belt Supergroup exposed in more southerly parts of the Cordillera. A direct biostratigraphic correlation of the Tindir with the Belt, however, has not been possible because the stromatolites in the Belt, unlike those in the Tindir, are not the columnar, or coneshaped, types found to be useful for correlation (M. A. Semihatov, oral commun., 1969). A comparison of radiometric dates from the Belt (Obradovich and Peterman, 1968) with those from the late Precambrian of Siberia suggests indirectly that the upper part of the Tindir is late middle Riphean in age, 950-1,350 \pm 50 m.y. (million years) (M. A. Semihatov, oral commun., 1969), and correlates with the upper part of the Belt Supergroup.

The base of the Tindir is not known, but rare boulders of granitic rock and gneiss in the upper part of the Tindir suggest that an igneous and metamorphic rock basement of earlier Precambrian age is not far away. Metamorphic rocks in the Yukon-Tanana Upland have been postulated as representing this earlier Precambrian (Mertie, 1937b), but isotope dating of these rocks has generally not verified their postulated Precambrian age.

In the western part of the Charley River quadrangle, 50-70 miles west of the Tindir's type area, are unmetamorphosed sequences of limestone, argillite, basaltic lava, and distinctively laminated dolomite that resemble the rocks of the Tindir Group (Brabb and Churkin, 1965). Stromatolites like those in the dolomite and shale member of the Tindir (M. A. Semihatov, written commun., 1968) also occur in these western exposures, indicating a much larger distribution of late Precambrian rocks in east-central Alaska than formerly recognized. Simi- 
larly laminated dolomites, again closely associated with basaltic lavas but containing nondiagnostic stromatolites that may be either Proterozoic or Paleozoic (M. A. Semihatov, oral commun., 1969), also occur in the Livengood district still farther west (Michael Churkin, Jr., unpub. field data).

Along the Porcupine River, some $\mathbf{1 5 0}$ miles north of the Tindir section on the Yukon, is a section, mainly of quartzite and dolomite, that has been included in the Tindir Group by Cairnes (1914). The following is a composite section made from exposures within a 5-mile distance upstream and downstream from New Rampart House where the international border crosses the Porcupine River (Brosgé and others, 1966) :

Devonian.

Massive dolomite and limestone. Abundant Amphipora and Cladopora.

Fault zone.

Precambrian(?).

Tindir(?) Group:

Argillaceous dolomite member: Thin bedded to laminated, platy and slabby. Black chert nodules and layers. About $\mathbf{4 0} \mathrm{ft}$ thick.

Upper dolomite member: Massive dolomite. About $400 \mathrm{ft}$ thick.

Black shale and thin-bedded limestone member. About 300 ft thick.

Lower dolomite member: Massive dolomite. About $200 \mathrm{ft}$ thick.

Upper quartzite member: Very light gray, fine grained, thin bedded, and cross laminated. About $800 \mathrm{ft}$ thick.

Sandstone and shale member: Interbedded quartzarenite, shale, and siltstone; weathers grayish red. About $250 \mathrm{ft}$ thick.

Lower quartzite member: White to light greenish gray, fine grained, cross laminated. More than 300 ft thick.

Total of 2,650 ft of rock exposed.

Base of section covered.

Correlation of this Porcupine River section with the Yukon River section of the Tindir is not possible with the data at hand. The Tindir(?) of the Porcupine River has some of the lithologies exposed farther south, but it has proportionately more dolomite and quartzite and less shale (fig. 3). A brachiopod and gastropod collection from a quartzite section 50 miles north of the Porcupine River suggests that some of the Tindir-like rocks in that area may be Paleozoic (Brosgé and Reiser, 1969).

OLDER SCHISTS OF UNCERTAIN AGE

The name "Birch Creek Schist" was first applied to schists in the Circle, Fairbanks, and Fortymile mining districts of the Yukon-Tanana Upland by
Spurr (1898). Various authors subsequently extended the term to include most of the high-grade metamorphic rocks in the interior of Alaska north of the Alaska Range. Then followed a period of restricting the term to include only rocks thought to be Precambrian (Mertie, 1937b). Originally, the Birch Creek Schist was assigned to the Precambrian on the basis of its apparent structural position below Paleozoic rocks and its high metamorphic grade. This Precambrian age assignment has continued (Mertie, 1937b; Dutro and Payne, 1957), but without conclusive confirmation of its age based on stratigraphic relations, and more recently was revised by Péwé and others (1966) and Wahrhaftig (1968) to Precambrian or Paleozoic.

The Birch Creek Schist in its type area near Circle consists largely of quartz-mica schist and chlorite schist produced apparently by regional metamorphism of mainly sedimentary rocks. Minor amounts of gneiss, marble, serpentine, and greenstone are interlayered with the schist. Well-developed zones of contact metamorphism border most of the granitic intrusions in the Birch Creek Schist. Isotopic measurements using strontium-rubidium and potassium-argon on micas from the schist and on granites intruding it indicate that the Birch Creek has been partly recrystallized at about $180 \mathrm{~m} . \mathrm{y}$. in conjunction with the granitic intrusions (Wasserburg and others, 1963). Besides the usual Mesozoic dates, a $474 \pm 35-m . y$. date has been obtained analyzing potassium-argon from hornblende in the schist (Forbes and others, 1968). According to Forbes, this early Paleozoic date on the polymetamorphic rocks of the Birch Creek lends support to their being derived in part by metamorphism of Precambrian rocks.

Recent mapping in the Yukon-Tanana Upland (Brabb and Churkin, 1969; H. L. Foster, 1969), the Fairbanks district (Péwé and others, 1966; Forbes and others, 1968), and the northern Alaska Range (Wahrhaftig, 1968; J. M. Hoare, unpub. data, 1967) indicates that the Birch Creek Schist is composed of polymetamorphosed sequences in which the metamorphic grade, as determined by different mineral assemblages, changes from place to place. Some of these mineralogical changes, accompanied by changes in penetrative structures, are abrupt and, according to Forbes and others (1968), can be related to juxtaposition of different metamorphic facies by faulting. In the Charley River quadrangle southeast of its type area, the biotite- and garnetbearing Birch Creek Schist grades irregularly into, or in places is faulted against, lower grade chlorite 


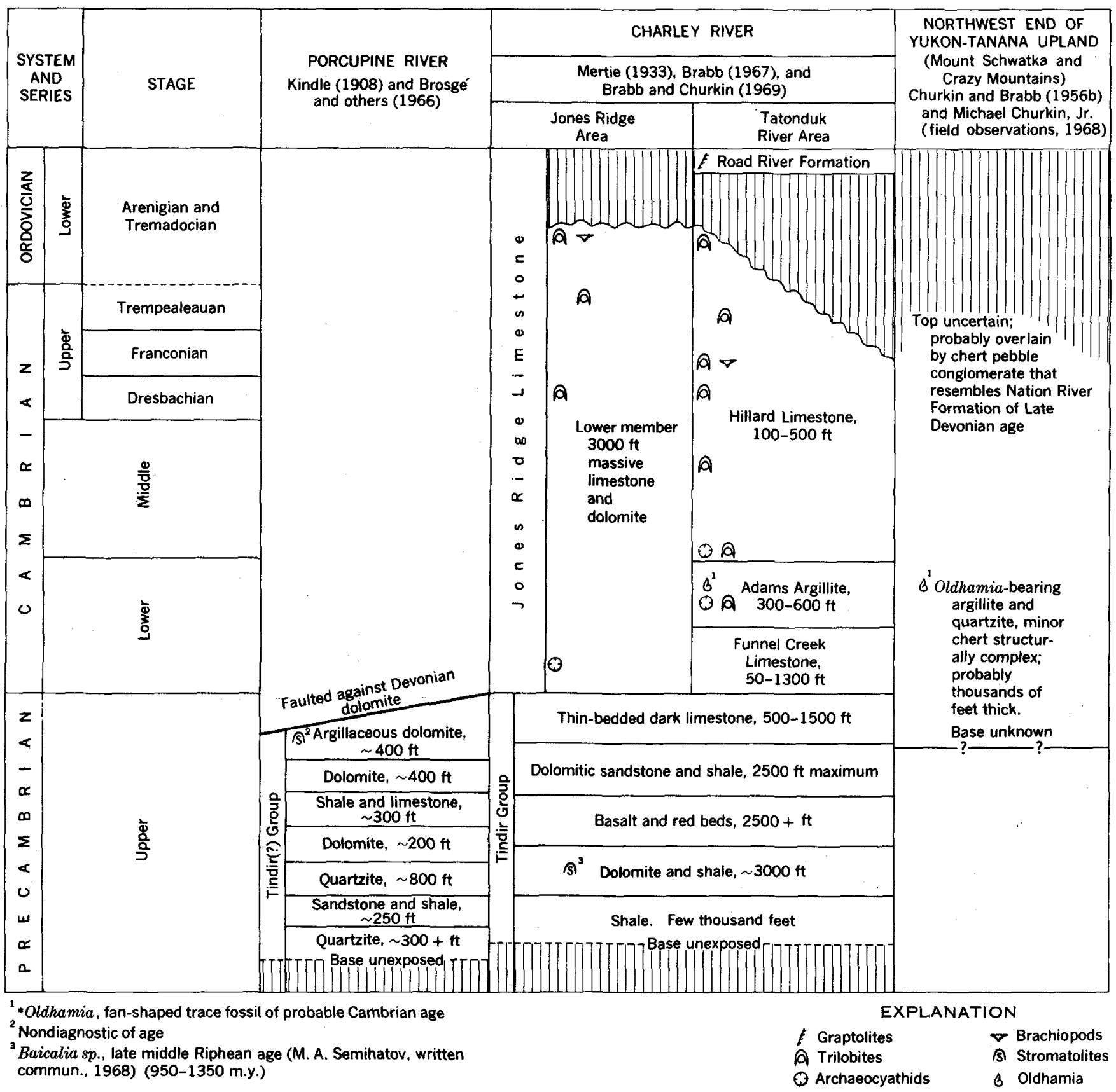

FiguRe 3.-Columnar sections of late Precambrian and Cambrian rocks in east-central Alaska.

and sericite schists, phyllite, and sheared conglomerate and chert (Brabb and Churkin, 1969).

In the lower grade rocks, relicts of original sedimentary layering are readily visible, and in several places marble interstratified with schist contains crinoid columnals (Mertie, 1930b, p. 44), presumably of Paleozoic, but possibly of younger age. Two of these crinoid localities are especially significant because they occur along the international boundary in rocks that were mapped by Cairnes (1914) as part of the Yukon Group that he considered to be Precambrian in age and to include the Birch Creek Schist. Fossil fungi of probable Paleozoic age (P. E. Cloud and G. Lucari, oral commun., 1968) have also been identified from within this belt of lower grade rocks.

North and west of its type area, the Birch Creek Schist is again rimmed by a belt of lower grade 
metamorphic rocks. Remnants of shelly fossils in highly deformed and recrystallized limestones in the Crazy Mountains and, farther west, in the Livengood area indicate that these low-grade metamorphic rocks are at least in part Phanerozoic in age ( $R$. M. Chapman, F. R. Weber, and Michael Churkin, $\mathrm{Jr}$., unpub. field observations). The presence of the fan-shaped trace fossil Oldhamia in phyllitic shale interbedded with quartzite indicates that part of this sequence is probably Cambrian (Churkin and Brabb, 1965b). Positive evidence that the Birch Creek Schist is derived in part from Precambrian strata depends on future isotopic dating of some relict minerals that have not been recrystallized by the Mesozoic intrusive bodies and later structural events, or on definitely establishing the stratigraphic position of the schist below an as yet undiscovered fossiliferous section of Cambrian age.

In the highlands between the Yukon and Kuskokwin Rivers of western Alaska (fig. 2), there are extensive areas of metamorphic rock. These schists, although sometimes correlated with the Birch Creek Schist, are without any positive evidence of their age.

In the Seward Peninsula the oldest rocks, long thought to be Precambrian, are slate and sandstone at the west tip of the peninsula and schists of the Kigluaik and Nome Groups in the vicinity of Nome (Moffit, 1913). A limestone of Ordovician age, the oldest fossil-bearing rock in the Seward Peninsula, was believed to overlie these weakly metamorphosed slates of supposed Precambrian age (Collier, 1902; Steidtmann and Cathcart, 1922). Regional mapping by Sainsbury (1969a) indicates that the Ordovician limestones, formerly assigned to the nowabandoned Port Clarence Limestone, are not in stratigraphic contact with the underlying slate but, instead, are thrust over it. According to Sainsbury (1969a), the Ordovician limestone is conformably underlain by a nonfossiliferous argillaceous and dolomitic limestone sequence several thousand feet thick that could include rocks of Cambrian or even late Precambrian age. The Kigluaik Group exposed in the west-central part of the Seward Peninsula presents the best evidence that it and other highgrade metamorphic rocks in the area are considerably older than the surrounding lower Paleozoic limestones and may be Precambrian. The Kigluaik Group, consisting mainly of mica schist, is exposed in a long west-trending structural arch that exposes higher grade gneisses in its core (Collier and others, 1908 ; C. L. Sainsbury, oral commun., 1968). The schistosity and compositional layering are arched along the axis of the structure, and lower grade schists interlayered with marble form the structurally higher parts of the sequence (C. L. Sainsbury, oral commun., 1968). Massive limestones rich in early Paleozoic fossils flank this arch and are virtually unmetamorphosed, thereby suggesting that they are considerably younger than the schists. Radiometric dating using potassium-argon isotopes of metamorphic rocks and associated intrusions in the Seward Peninsula generally indicates metamorphic-plutonic events of Mesozoic age (Sainsbury, 1969a). In exception, Sainsbury (written commun., 1970) has obtained a 750-m.y. date on gneiss from the core of the Kigluaik Mountains using the rubidium-strontium whole-rock method. A dike cutting this gneiss, according to Sainsbury, gives a 450-m.y. $\mathrm{Rb}: \mathrm{Sr}$ date.

Metamorphic rocks with structural and stratigraphic relations similar to those in the Seward Peninsula have been described from Chukotsk Peninsula across the narrow Bering Strait (Belyi, 1964; Krasniy, 1966, p. 46; Gnibidenko, 1969). 'Based largely on their high metamorphic grade, these rocks in Chukotka have generally been considered Precambrian (Tilman, 1962; Belyi, 1964). Radiometric dating (24 separate analyses) shows that in the Chukotsk Peninsula, as in other metamorphic terranes around the northwestern Pacific, the age of the metamorphism ranges from Paleozoic to Mesozoic but is mostly Mesozoic in the interval of 130-60 m.y. (Gnibidenko, 1969). In eastern Chukotka, numerous older dates, ranging from about 1,500 to 700 m.y., have been obtained on rocks in the same vicinity as those giving the younger dates (Gnibidenko, 1969). These dates suggest that some Precambrian rock may be involved in the mainly Mesozoic metamorphism. It seems reasonable to consider these metamorphic rocks as earliest Paleozoic where they grade into fossiliferous Paleozoic rocks and as provisionally Precambrian where there is a sharp structural break between them and fossiliferous lower Paleozoic rocks.

In addition to the belt of metamorphic rocks across the center of Alaska, there are metamorphic rocks in other regions of Alaska that some have suspected of being early Paleozoic in age and others have suspected of being Precambrian-the Wales Group of southeastern Alaska (Buddington and Chapin, 1929); a narrow belt of rocks along the southern margin of the Brooks Range (Patton, 1957; Brosgé, 1960); and the Neruokpuk Formation of the northeastern Brooks Range (Brosgé and others, 1962; Reiser, 1970). These rocks, without 
further work, cannot be accurately dated; but some are almost certainly of Paleozoic age. The occurrence of any strata conclusively dated as Precambrian in these metamorphic complexes has not been recorded. However, the discovery of Cambrian trilobites (J. T. Dutro, Jr., W. P. Brosgé, and H. N. Reiser, written commun. and unpub. data, 1971) in the Neruokpuk Formation, and the knowledge that Silurian graptolites in the Barn Mountains-Yukon Territory are closely associated with rocks correlated with the Neruokpuk, indicate that some earliest Paleozoic strata are included in the metamorphic rocks of the northeastern Brooks Range.

LOWER PALEOZOIC CYCLE OF SEDIMENTATION

The Cambrian through Middle Devonian rocks in east-central Alaska seem to be part of a cycle of nearly continuous sedimentation. In contrast, starting in the Late Devonian, apparently older geosynclinal rocks within the Cordilleran and ancestral Brooks geosynclines were uplifted, and wedges of coarse siliceous sediments, in part nonmarine, were deposited towards the interior of Alaska.

\section{CAMBRIAN ROCKS}

Cambrian rocks have been found in Alaska only in a small area at the west end of the Ogilvie Mountains, where the Yukon River crosses the international boundary (fig. 4). ${ }^{1}$ Fossils of definite Cambrian age were first reported here by Cairnes (1914), and the stratigraphic succession has been subsequently described by Mertie (1933) and Brabb (1967). Kobayashi (1935) and Palmer (1968) have described the trilobite and brachiopod faunas.

The Cambrian in most of this area is represented by a limestone and dolomite section that has shale and quartzite in its middle part (Charley River area, fig. 3). In exception, the Cambrian exposures in the northeastern part of the area (Jones Ridge to Squaw Mountain) are all limestone and dolomite. The contact of the Cambrian with rocks of the Tindir Group is accordant and probably conformable. The Hillard Limestone, at the top of the Cambrian section, is overlain by a chert and shale unit (Road River Formation), the basal part of which contains a rich late Early Ordovician graptolite fauna (Churkin and Brabb, 1965a). The Road River Formation rests unconformably on different beds of the Hillard Limestone ranging in age from Early Cambrian to Early Ordovician (Brabb, 1967; fig. 3).

Abundant specimens of Oldhamia, a fossil of probable Cambrian age found in the Adams Argillite,

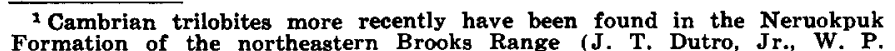
Formation of the northeastern Brooks Range (J. T. Dutro, $\mathrm{Jr}_{\text {.̈. }} \mathrm{W}$.
Brosgé, and $\mathrm{H}$. N. Reiser, written commun. and unpub. data, 1971).
}

also occur in similar argillite and quartzite near Mount Schwatka in the Crazy Mountains (fig. 4), about 180 and 100 miles, respectively, west of the Cambrian section along the international boundary. Their occurrence suggests that large areas of terrigenous rocks in the central interior of Alaska, mapped originally by Mertie (1937b) as "undifferentiated noncalcareous rocks of Devonian age" or as "undifferentiated noncalcareous rocks of Mississippian age," include much older rocks of probable Cambrian age (Churkin and Brabb, 1965b).

Other areas in which Cambrian rocks may eventually be recognized are primarily the areas of Ordovician outcrop shown in figure 5. Especially promising are the well-bedded limestone sequences on the Seward Peninsula where, according to Sainsbury (1969a), there are thousands of feet of argillaceous and dolomitic limestone stratigraphically below massive limestone containing Early Ordovician fossils.

\section{ORDOVICIAN ROCKS}

Ordovician rocks of different facies have been recognized in many widely separated areas of Alaska (fig. 5). The stratigraphic succession within these areas of Ordovician strata, however, is known in any detail only in the Eagle area of east-central Alaska (Churkin and Brabb, 1965a), in the Craig area of southeastern Alaska (Eberlein and Churkin, 1970), and in the Seward Peninsula (Sainsbury, 1969a). The remaining areas of Ordovician rock shown in figure 5 either are based on collections of Ordovician fossils made during the earliest reconnaissance surveys (locs. 2-4) or are structurally complex areas in which the stratigraphic relations of the Ordovician rocks to other rocks is unknown (locs. 5, 7).

Two facies of Ordovician rocks are developed in the Charley River area near the international boundary (fig. 6). Along the south edge of the area, graptolitic shale and chert (Road River Formation) form a belt that extends for 35 miles along the Yukon River. Only 7 miles north of exposures of the graptolitic shale facies is a contemporaneous pure limestone section (Jones Ridge Limestone) that is several times as thick as the shale. This abrupt change in lithology is believed to reflect a rapid facies change and is comparable to similar changes of graptolitic shale into carbonate rock farther east in Yukon Territory (Churkin and Brabb, 1967).

The graptolitic shale and chert section, in the lower part of the Road River Formation, rests unconformably on the Hillard Limestone. The base of this section is marked by a few feet of black bedded 


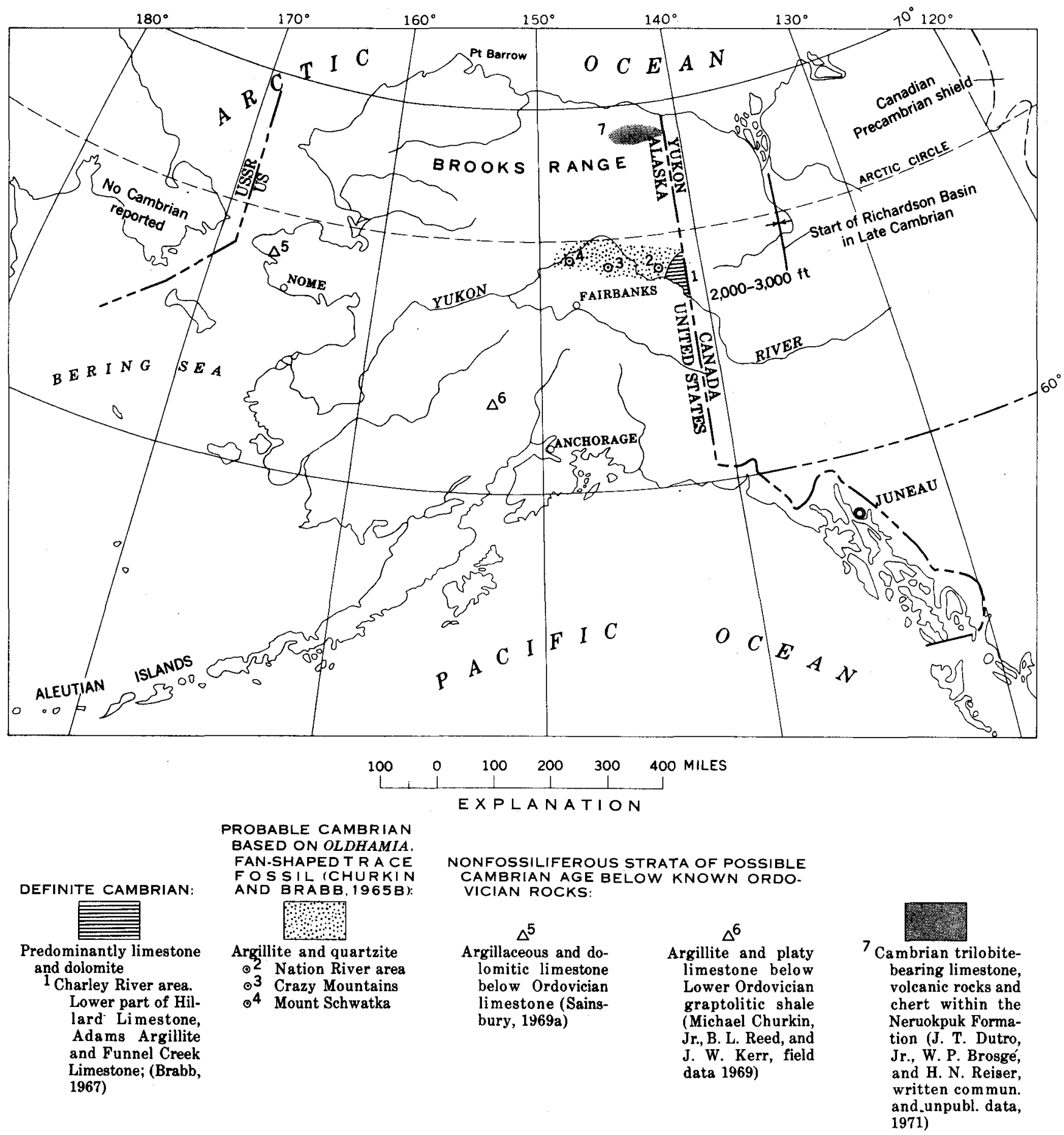

Figure 4.-Cambrian rocks of Alaska. 


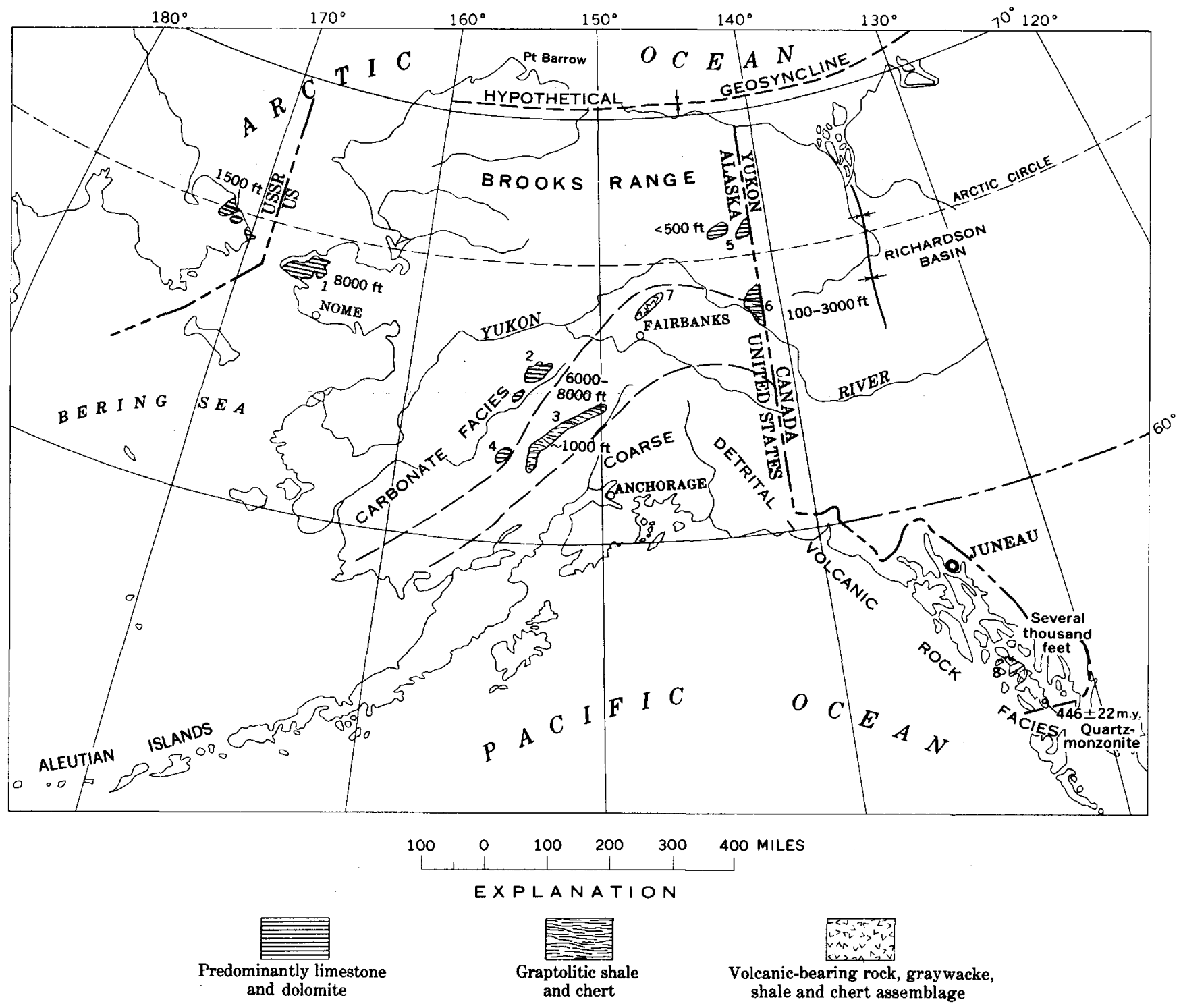

Figure 5.-Ordovician rocks of Alaska.

\section{SOURCES OF DATA}

1. Seward Peninsula:

Limestone (Steidtmann and Cathcart, 1922; Sainsbury, 1969a).

2. Upper Kuskokwim River:

(Eakin, 1918; Brown, 1926).

3. Alaska Range:

Tatina Group (Brooks, 1911).

Terra Cotta Mountain sequence (Michael Churkin, Jr., B. L. Reed, and J. W. Kerr, field observations, 1969).

4. White Mountain area:

(Sainsbury, 1965).

5. Porcupine River:

(Kindle, 1908; Cairnes, 1914a, b; Brosgé and others, 1966).

6. Charley River area:

Lower part of Road River Formation, upper part of
Jones Ridge Limestone (Churkin and Brabb, 1965a; Brabb, 1967).

7. Livengood area:

Fossil Creek Volcanics (Mertie, 1937b) ; shelly fossils reported to be in uppermost Fossil Creek Volcanics can be interpreted as coming from basal part of overlying Tolovana Limestone (Michael Churkin, Jr., field observations, 1968).

8. Alexander Archipelago:

Lower part of Descon Formation (Buddington and Chapin, 1929; Brew and others, 1966; Eberlein and Churkin, 1970).

Radiometric date:

$446 \pm 22$ m.y. Bokan Mountain area, southeastern Alaska (Lanphere, MacKevett, and Stern, 1964). 


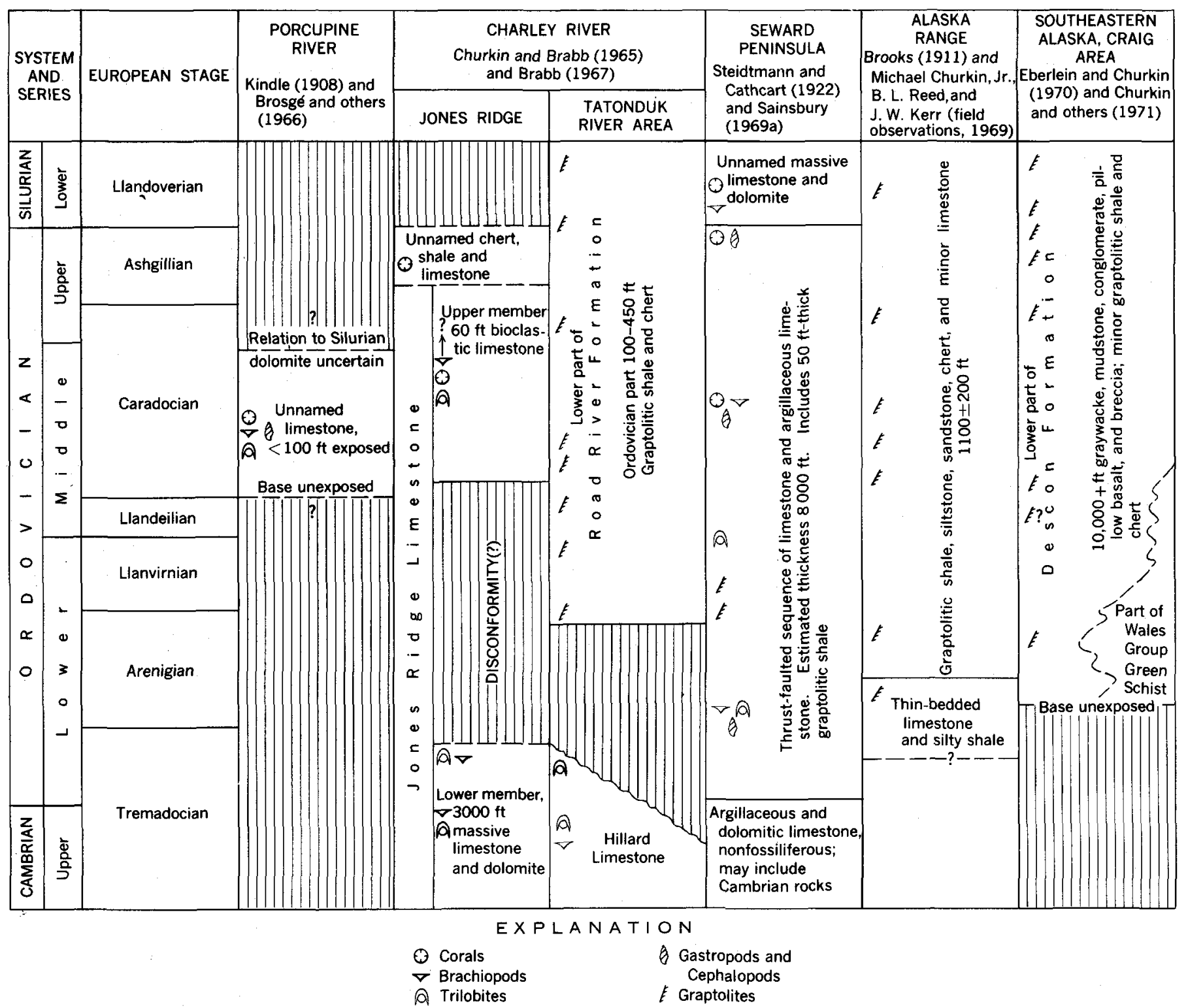

FIgURE 6.-Correlation chart of Ordovician rocks.

chert and chert conglomerate containing a coquina of phosphatic shells of the pod-shaped crustacean, Caryocaris (Churkin, 1966). A rich sequence of graptolite faunas indicates that the Road River includes all the Ordovician except for the earliest Ordovician (Tremadocian and lower part of the Arenigian). The Road River Formation is discontinuously exposed, but in all the sections that span the Ordovician-Silurian boundary there is no evidence of a stratigraphic break coinciding with the systemic boundary (Churkin and Brabb, 1965a).

In the Jones Ridge area near the Alaska-Yukon Territory boundary the Ordovician is represented by pure limestone, except for a 60 -foot, largely covered, interval of chert, shale, and minor limestone that may represent a wedge of Road River Formation lithology (Brabb, 1967). Farther north, along the international boundary, the Ordovician seems to be represented by a pure limestone section that continues north as far as the Porcupine River. Along the Porcupine River itself, there is very fine grained limestone that contains the easily identifiable tabulate coral Tetradium together with other Ordovician shelly fossils (Kindle, 1908; Brosgé and others, 1966).

Outside of east-central Alaska the only other areas 
with Ordovician rocks that are mainly carbonate lie in western Alaska. In the Seward Peninsula, the Port Clarence Limestone of former usage and numerous mappable subdivisions consist mainly of limestone but also have dolomitic and argillaceous interbeds. In the central York Mountains these rocks aggregate at least 8,000 feet in thickness and include Lower, Middle, and Upper Ordovician rocks (Sainsbury, 1969a).

Farther south in the upper reaches of the Kuskokwim River, northeast of McGrath, Ordovician shelly faunas have been reported from a nearly pure limestone and dolomite section (Eakin, 1918; Brown, 1926). The Holitna Group of virtually pure carbonate rock farther west in the central Kuskokwim area may also include Ordovician rocks because Silurian and Devonian faunas were collected from its upper horizons (Cady and others, 1955). Farther south in the White Mountain area, Ordovician fossils were found in limestone sections that have many interbeds of argillaceous, silty, and sandy rocks (Sainsbury, 1965). Very similar Ordovician limestones on Chukotsk Peninsula (Krasniy, 1966, p. 74; S. G. Byalobzheskii, oral commun., 1967; Gnibidenko, 1969) suggest this belt of carbonate rock in west-central Alaska continues from the Seward Peninsula west beneath the Bering Strait to the northeastern tip of the U.S.S.R.

In the Terra Cotta Mountains of the Alaska Range south of Farewell, a thin, though relatively complete, section several thousand feet thick of graptolitic shale interbedded with limestone and sandstone has been established as ranging in age from the earliest Ordovician through the Silurian (Michael Churkin, Jr., and B. L. Reed, unpub. data). These sections in the Alaska Range, like the Road River Formation farther east, suggest a transition from the carbonate rock facies exposed in isolated areas across the center of Alaska to the coarse detrital rock sequences of southeastern Alaska.

In contrast to the predominantly carbonate facies of Ordovician rock in the interior and western parts of Alaska, a thick sequence of graywacke, argillaceous rock, and conglomerate rich in volcanic detritus and interlayered with pillow lavas, tuffs, and breccias is exposed in southeastern Alaska (Buddington and Chapin, 1929; Sainsbury, 1961; Eberlein and Churkin, 1970). Limestone is absent in this sequence, except for scattered thin lenses of nonfossiliferous dark limestone and for rare cobbles and boulders of dense limestone in graywacke conglomerates. Graptolite faunas in this sequence indicate that all the major subdivisions of the Ordovician are present, except for the lower parts of the Early Ordovician (Tremadocian and lower Arenigian), which may be present but may not be exposed because the base of the section is not known. Deposition of the graywacke-volcanic assemblage was continuous through most of the Ordovician and Early Silurian (Llandoverian) but changed locally into very thick limestone accumulation by Middle Silurian (Wenlockian) time (Eberlein and Churkin, 1970).

The volcanic rocks that appear sporadically throughout the entire Paleozoic section of southeastern Alaska are alkali-rich basaltic to andesitic pillow lavas, breccias, and tuffs grading in many places into conglomerates and sandstones rich in volcanic fragments. Graptolites from interbedded shales in the lower part of the section date a succession of submarine volcanism from different centers during Early Ordovician through Early Silurian time. Local disconformities and thick wedges of volcanic-boulder conglomerate indicate repeated uplift that was in part probably related to volcanism. A potassium-argon isotope date of $446 \pm 22$ m.y. on a quartz monzonite pluton in Prince of Wales Island (Lanphere and others, 1964) further indicates that a period of magma generation accompanied the orogenic activity. Granitic boulders in the Ordovician conglomerates could have been locally derived from intrusions of about this age.

In contrast to the generally coarsely detrital sediments in southeastern Alaska, there is also a lithofacies of thinly and rhythmically interbedded black chert and siliceous graptolitic shale (member of the Descon Formation). These rocks, in their lithology and fossils, very closely resemble parts of the Road River Formation of east-central Alaska and the graptolitic shales in the Terra Cotta Mountains of the Alaska Range.

\section{SILURIAN ROCKS}

The Silurian rocks closely parallel the pattern of sedimentary facies established in Ordovician time. Furthermore, there does not seem to be a pronounced break in sedimentation across the OrdovicianSilurian boundary anywhere in Alaska (Churkin, 1972a).

The best known Silurian rocks are in the YukonPorcupine Rivers area and in southeastern Alaska (figs. 7, 8). Other areas from which Silurian fossils have been reported, but where the stratigraphy is less well known, are the Livengood-White Mountains area (fig. 7, No. 1), the Nixon Fork area in the upper Kuskokwim River drainage (fig. 7, No. 4), the middle Kuskokwim area (fig. 7, No. 5), and the 


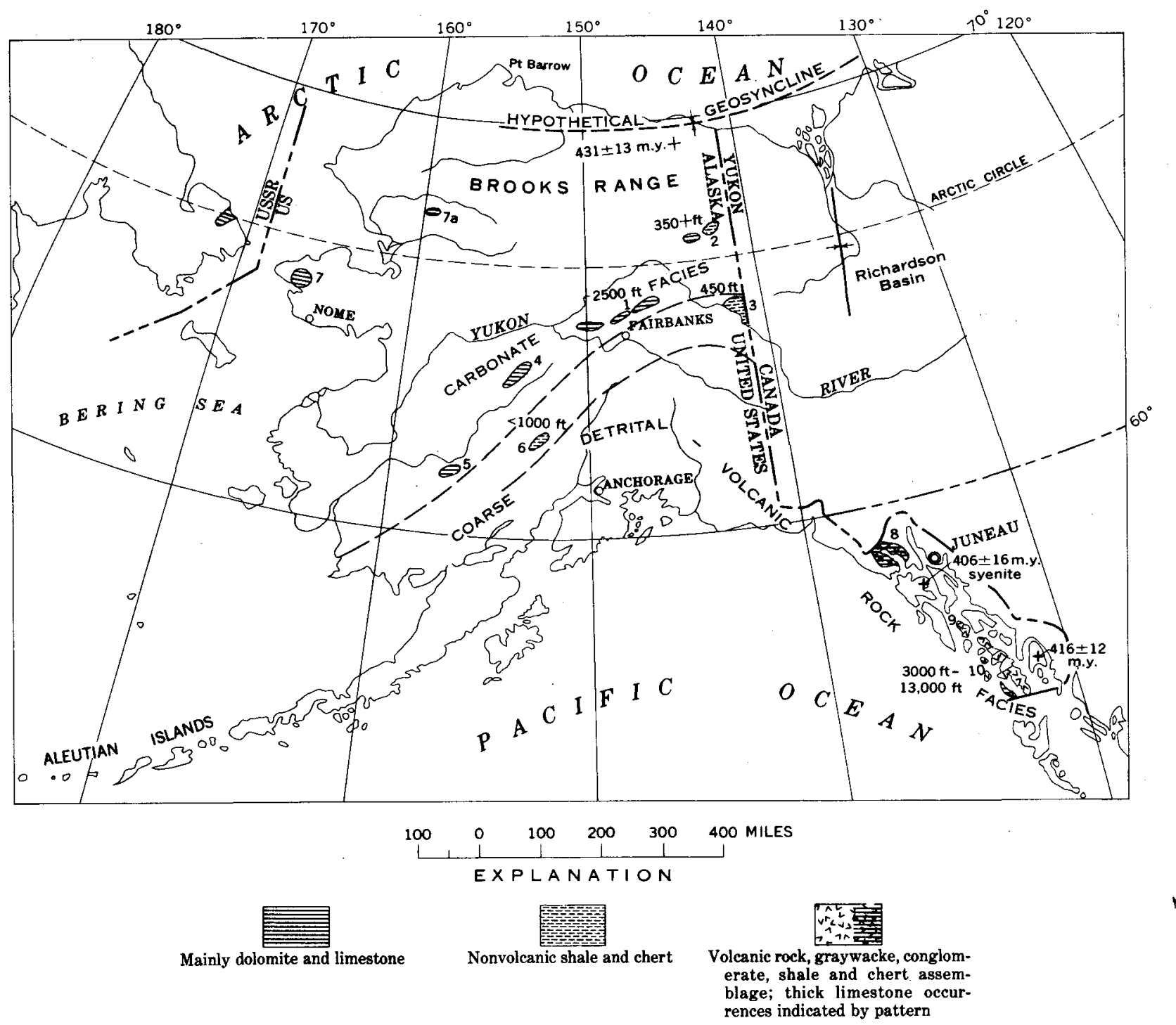

FiguRE 7.-Silurian rocks of Alaska.

\section{SOURCES OF DATA}

1. Livengood area :

Lower part of Tolovana Limestone (Mertie, 1937b; Church and Durfee, 1961; Péwé and others, 1966).

2. Porcupine River:

(Kindle, 1908; Churkin and Brabb, 1967).

3. Charley River area:

Middle part of Road River Formation (Churkin and Brabb, 1965a).

4. Upper Kuskokwim River:

(Brown, 1926).

5. Kuskokwim River:

Lower part of Holitna Group (Càdy and others, 1955).

6. Alaska Range (Terra Cotta Mountain sequence) :

(Michael Churkin, Jr., B. L. Reed, and J. W. Kerr, field data, 1969).

7. York Mountains:

(Sainsbury, 1969a).

7a. Northeastern Baird Mountains:

Thrust slice of Skajit(?) Limestone (Tailleur and others, 1967 , p. 1352).

8. Glacier Bay:

Willoughby Limestone; Tidal Formation; Pyramid Peak Limestone; and Rendu Formation (Rossman, 1963).

9. Kosciusko Island:

Bay of Pillars Formation; Kuiu Limestone (Muffer, 1967).

10. Prince of Wales Island area :

Upper part of Descon Formation; Heceta Limestone; lower part of Karheen Formation (Buddington and Chapin, 1929; Brew and others, 1966; Eberlein and Churkin, 1970; Ovenshine and Webster, 1970).

Radiometric dates:

431 m.y. Satellitic intrusion to main granite body in Romanzof Mountains (Reiser, 1970).

406 m.y. Tenakee area, Chichagof Island (Lanphere and others, 1965).

416 m.y. Annette Island (Berg, 1970). 


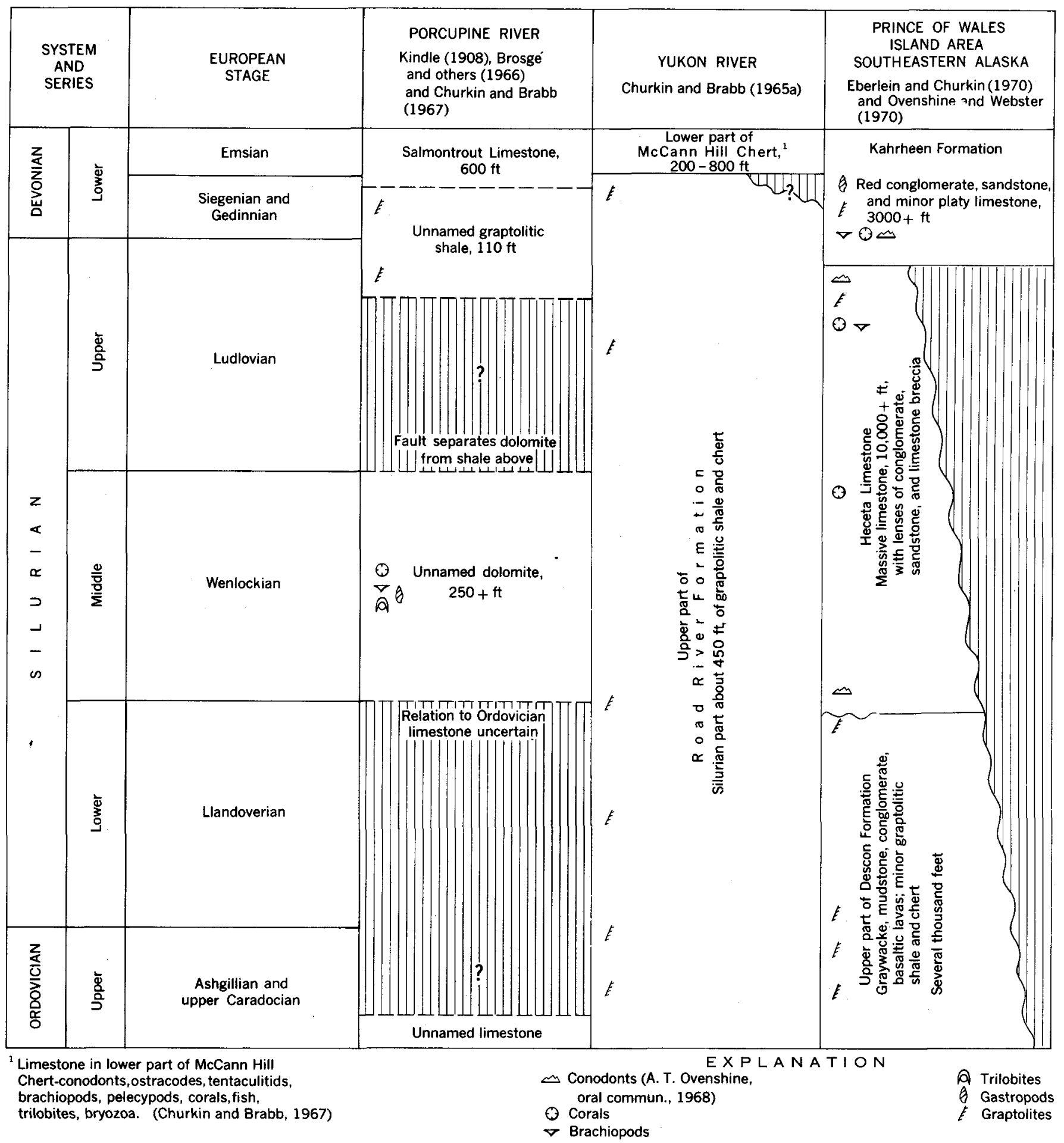

FIGURe 8.-Correlation chart of Silurian rocks. 
central York Mountains of the Seward Peninsula (fig. 7, No. 7).

In the southern Brooks Range, a widely distributed massive limestone, the Skajit Limestone, was assigned to the Silurian until Dutro (in Brosgé and others, 1962) determined that the large brachiopods in the Skajit first thought to be Conchidium, a Silurian guide fossil, are really Stringocephalus, a cosmopolitan genus known only from the Devonian. More recently, a pentameroid brachiopod of probable Silurian age (Dutro, in Tailleur and others, 1967) is reported from limestone questionably mapped as Skajit in the northeastern part of the Baird Mountains of the western Brooks Range. Silurian and older rocks may be present in the lowgrade metamorphic belt in the southern Brooks Range, within the thick Neruokpuk Formation of the northeastern Brooks Range (especially since Silurian graptolites have been reported in close association with the Neruokpuk Formation in the Barn Mountains of northern Yukon Territory) and in the Sadlerochit Mountains where a thick sequence of dolomite occurs below limestone of Devonian age (Dutro, 1970). A single potassiumargon isotope date of $\mathbf{4 7 5}$ m.y. on hornblende in a mafic volcanic rock from the Doonerak Mountain area of the south-central Brooks Range suggests that the volcanic rock and associated slate and shale there may be Ordovician (Lanphere, 1965), thus supporting an early Paleozoic age for some of the weakly metamorphosed nonfossiliferous rocks that are widely distributed in the Brooks Range.

A few collections from limestones on the Seward Peninsula have been reported to contain Silurian and Devonian shelly fossils along with the more numerous Ordovician faunas (Smith and Eakin, 1911 ; Sainsbury, 1969a). Undoubtedly, with further work it will be possible to separate units of widely varying ages in this area of predominantly carbonate rocks. Work in the Don River area north of Teller has established a richly fossiliferous limestone-dolomite succession that spans the OrdovicianSilurian boundary with no apparent stratigraphic break (Sainsbury and others, 1971). The virtually pure carbonate rocks in the Kuskokwim region suggest that this stratigraphic belt covers much of southwestern Alaska before it becomes an argillaceous facies along the southern margin of the Kuskokwim region (Cady and others, 1955).

Farther south, in the Alaska Range, Silurian rocks had not been reported until recently. The Paleozoic sequences there are mainly siliceous, detrital, and volcanic rocks that appear to be transitional and, in some places, similar to the volcanic-rich siliceous detrital facies of south Alaska. In 1969 the first Silurian fossils were found in this remote area (Michael Churkin, Jr., B. L. Reed, and J. W. Kerr, unpub. data). They are well-preserved graptolite faunas near the top of a rather thin interval of rhythmically interbedded shale and siliceous shale. Subsequently, Silurian graptolites have been found from a number of horizons in a stratigraphically higher platy limestone and sandstone section.

In the central interior of Alaska and extending across the Porcupine-Yukon triangle is an area of discontinuous exposures of carbonate rock of Silurian age. In the White Mountains north of Fairbanks, the 2,500-foot-thick Tolovana Limestone rests on the Fossil Creek Volcanics, reportedly of Ordovician age (Mertie, 1937b). In detail, the massive limestone and dolomite of the Tolovana is directly underlain by a poorly exposed section several feet thick of tuffaceous carbonate rock containing tabulate corals in growth position (Michael Churkin, Jr., R. M. Chapman, and F. R. Weber, field observations, 1968). The tuff grades downward into a thick conglomerate made of volcanic and plutonic rock boulders which, in turn, lies on a section, thousands of feet thick, of siliceous clastic rocks and pillow lavas, the Fossil Creek Volcanics proper.

Farther east along the Porcupine River, massive limestone and dolomite of Silurian age form high bluffs in the Lower Ramparts area. A thin (100-ftthick) unit of black shale, best exposed at the mouth of the Salmontrout River, has Late Silurian (Ludlovian) graptolites in its lower part and Early Devonian graptolites in its ur ver part (Churkin and Brabb, 1967). Similar shale with the same Late Silurian graptolites is exposed downstream in the Lower Ramparts where it seems to overlie the massive Silurian carbonate rocks. Thus, the Silurian succession along the Porcupine River resembles the Ordovician facies on the Seward Peninsula, being mainly carbonate rock with a thin horizon of graptolitic shale. Apparently, the predominantly carbonate facies exposed along the Porcupine River continues south into the Charley River quadrangle, where the Silurian section rapidly changes from carbonate rock at Jones Ridge to the pure graptolitic shale and bedded chert farther south along the Yukon River. The Silurian-Devonian boundary in the Porcupine River section, as in the Yukon River section, is not marked by a stratigraphic break but lies within a graptolitic shale formation.

From east-central Alaska this thin graptolitic shale and chert section continues eastward into 
Yukon Territory, where it is interrupted by a thick limestone buildup in the Illtyd Range, and finally grades into a platform section of dolomite mantling the Canadian Shield in Northwest Territories (Churkin and Brabb, 1967, fig. 10). Northeastward from the Charley River area, the graptolitic shale and chert thicken towards the Richardson Mountains, the type area of the Road River Formation (Jackson and Lenz, 1962).

Silurian rocks in southeastern Alaska are exposed in a series of islands at the continental margin (fig. $7)$. In the Craig area of southeastern Alaska, the sequences, mainly graywacke, shale, and conglomerate, characteristically have abundant volcanic detritus and are interlayered with submarine volcanic rocks (fig. 8). They are accurately dated as Early Silurian by graptolites (Churkin and Carter, 1970; Churkin, Carter, and Eberlein, 1971). The Middle and Upper Silurian in the same area, in sharp contrast with the underlying Lower Silurian and Ordovician, is mainly limestone (more than $10,000 \mathrm{ft}$ thick on Heceta Island; Eberlein and Churkin, 1970; Ovenshine and Webster, 1970). Silurian limestones also occur in Glacier Bay, on Northern Kuiu Island, on Heceta-Tuxekan Islands, and on Long Island (figs. 9, 10). The limestones vary from light-colored massive sublithographic limestone that makes up much of Heceta Island (Heceta Limestone) to dark thin-bedded argillaceous limestone (Tidal Formation) in Glacier Bay. Locally, thick lenses of polymictic conglomerate rich in volcanic detritus, limestone breccia, sandstone, and argillaceous rocks are interbedded with the purer limestone. Most of these limestones are rich in corals, stromatoporoids, brachibpods, gastropods, pelecypods, bryozoa, and calcareous algae. However, calcareous sandstone and argillite (Bay of Pillars Formation) that contain Late Silurian graptolites show that, in restricted areas, limestone deposition did not commence until the Late Silurian (Muffler, 1967).

\section{LOWER AND MIDDLE DEVONIAN ROCKS}

Devonian rocks are widespread in Alaska and form a nearly continuous belt in the Brooks Range across the northern part of the State (fig. 11). The Devonian System in Alaska was summarized for the International Symposium of the Devonian System held at Calgary (Gryc and others, 1967; Tailleur and others, 1967; Churkin and Brabb, 1967).

In the northern and east-central parts of Alaska, the Middle and, more rarely, the Lower Devonian sections, mainly limestone and dolomite, are part of a lower Paleozoic cycle of nearly continuous sedimen-

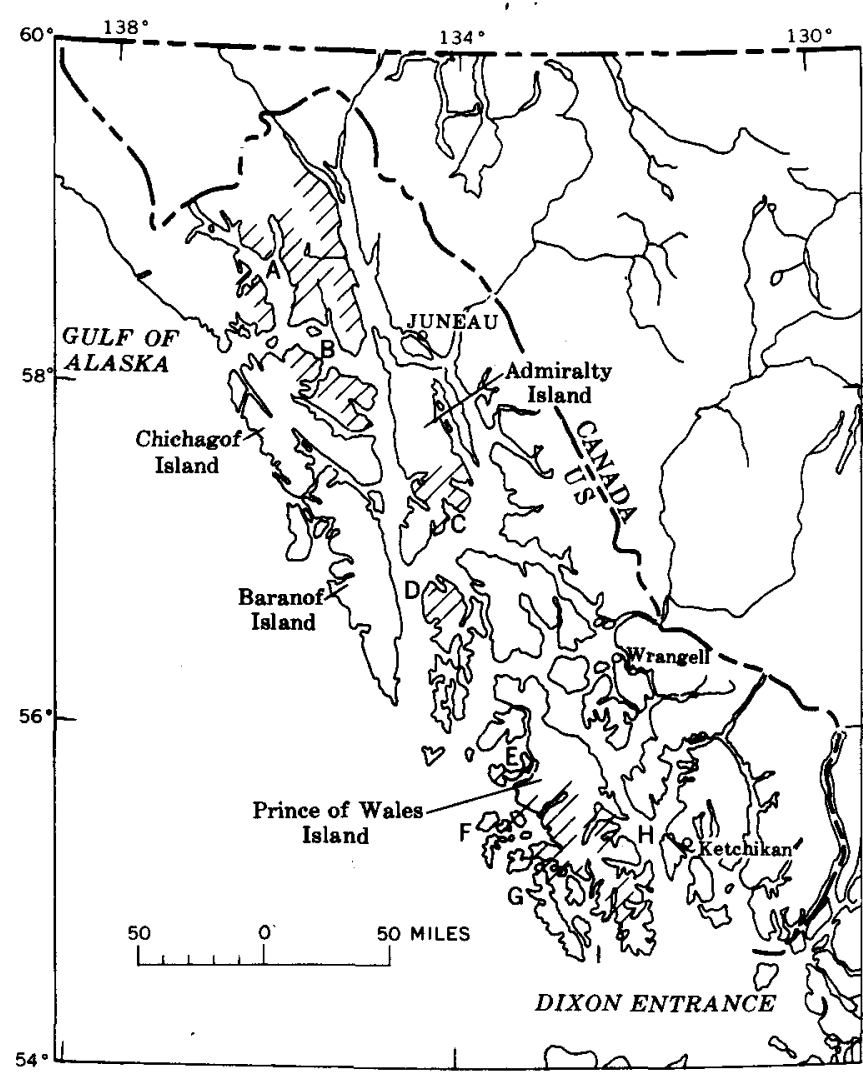

Figure 9.-Index map of southeastern Alaska. Hatch lines and letters indicate location of stratigraphic columns shown in figure 10.

tation that started in the latest Precambrian or Cambrian. Other areas where carbonate rocks predominate are in the Seward Peninsula and in the Kuskokwim River region (fig. 11) where relatively pure carbonate sections are known to contain Ordovician as well as Silurian and Devonian faunas.

In addition to these areas, more recent studies report the following occurrences of Devonian carbonate rocks: a dolomite section on St. Lawrence Island that lies below limestone that correlates with the Lisburne Group mainly of Carboniferous age (Patton and Dutro, 1969) ; coral-rich limestone just south of Farewell in the Alaska Range (B. L. Reed, oral commun., 1968; Michael Churkin, Jr., unpub. field observations, 1969) ; and limestone and dolomite in the Sadlerochit Mountains of northeastern Alaska (Dutro, 1970).

Besides these nearly pure carbonate sections, there are widely scattered areas of siliceous detrital and volcanic rocks that include subordinate limestones with Devonian fossils (locs. 8-13). These rocks probably represent a northern continuation of the stratigraphic belt in southeastern Alaska. 
The section of thinly and rhythmically interbedded dark shale and chert (McCann Hill Chert and the uppermost part of the Road River Formation) in the Eagle area of east-central Alaska seems to represent an intermediate facies separating the predominantly carbonate rocks found farther north from the siliceous detrital and volcanic rocks in southeastern Alaska (fig. 12). This relatively thin shale and chert section of Early Devonian age grades eastward into thicker limestone in the $\mathrm{Na}$ honi Range-Blackstone River area of Yukon Territory (Churkin and Brabb, 1967, fig. 10). The Silurian-Devonian boundary in this graptolitic shale sequence is placed above a Monograptus nilssoniLinograptus fauna of Late Silurian age and below shale with Monograptus yukonensis, in accordance with modern interpretations of this boundary elsewhere. Above the shale with $M$. yukonensis are thin limestone beds with a remarkably varied shelly fauna of Early Devonian age (Churkin and Brabb, 1967). At Jones Ridge, a short distance north of the Yukon River, these limestones thicken markedly.

Much farther north, the argillites at the bottom of a borehole at Point Barrow (Payne and others, 1951) and the Lower or Middle Devonian plantbearing shale and chert-pebble conglomerate from the Topagoruk test well, 50 miles farther south (Collins, 1958), seem to indicate a northward change of the Brooks Range Devonian carbonate section into siliceous terrigenous rocks. In the northeastern Brooks Range the largely clastic Neruokpuk Formation may include equivalents to these Devonian rocks found in the subsurface. In the Sadlerochit Mountains farther north, however, there is a thick Devonian carbonate section (Dutro, 1970). The Sadlerochit Mountain section is difficult to interpret; it may be an isolated buildup of carbonate rock, or it may indicate another major belt of carbonate rocks parallel to that of the central Brooks Range (fig. 11).

The Devonian of southeastern Alaska, like the underlying Ordovician and much of the Silurian, is mainly a graywacke, shale, and conglomerate sequence interbedded and intertongued with basaltic to andesitic pillow lava, breccia, and tuff. These submarine lavas and associated sedimentary rocks rich in volcanic detritus grade rapidly into thick limestones made up largely of fragmented fossils, especially in Glacier Bay, Freshwater Bay, and in several places along the west coast of Prince of Wales Island (fig. 10).
A good example of rapid facies change is seen in the vicinity of Craig where a nearly pure limestone section about 1,000 feet thick (Wadleigh Limestone), composed mainly of varying proportions of fragmented corals and stromatoporoids, intertongues at a place 4 miles to the south with 1,500 feet of basaltic tuff, breccia, and pillow lava. Several miles still farther south this limestone is entirely absent, apparently due to a facies change to a thick sequence (Port Refugio Formation) of pillow basalt, tuff, and volcanic breccia interbedded with graywacke, conglomerate, and shale (Eberlein and Churkin, 1970). The only limestone known in this sequence is a silty and tuffaceous limestone only a few tens of feet thick.

Over a large area of southeastern Alaska, the base of the Devonian is marked by a distinctive unit, predominantly conglomerate, sandstone, and shale, the Karheen Formation, that is characterized by red beds and festoon crossbedding. In the Heceta-Tuxekan Islands area, the Karheen conformably overlies thick limestone (HecetalLimestone) of Early through Late Silurian age and which, according to Kirk and Amsden (1952), has a Late Silurian brachiopod fauna above its base. Conodonts (A. T. Ovenshine, written commun., 1969) and a tentaculitid fauna (Claire Carter, written commun., 1969) from these beds seem to suggest instead an Early Devonian age. Farther south, the Karheen Formation rests unconformably on Ordovician to Lower Silurian volcaniclastic rocks and has an unusual assemblage of graptolites, vascular plants, and corals of Early Devonian age (Churkin and others, 1969, 1970).

\section{UPPER PALEOZOIC CYCLE OF SEDIMENTATION}

\section{UPPER DEVONIAN ROCKS}

The Upper Devonian Series is dominated by clastic rocks throughout Alaska. Chert-pebble conglomerate, sandstone, and shale (Kanayut and Hunt Fork Formations of the Brooks Range and the Nation River Formation of east-central Alaska) derived from uplifts within adjacent geosynclinal belts start a cycle of thick accumulation of coarse siliceous detrital sediments in interior Alaska (fig. 13).

In the northeastern Brooks Range, Mississippian conglomerate (Reiser, 1970) unconformably overlies the Neruokpuk Formation (regionally metamorphosed Devonian or older siliceous sedimentary rocks), and as much as 10,000 feet of Neruokpuk strata were removed by erosion below the unconformity (Reed, 1968). 


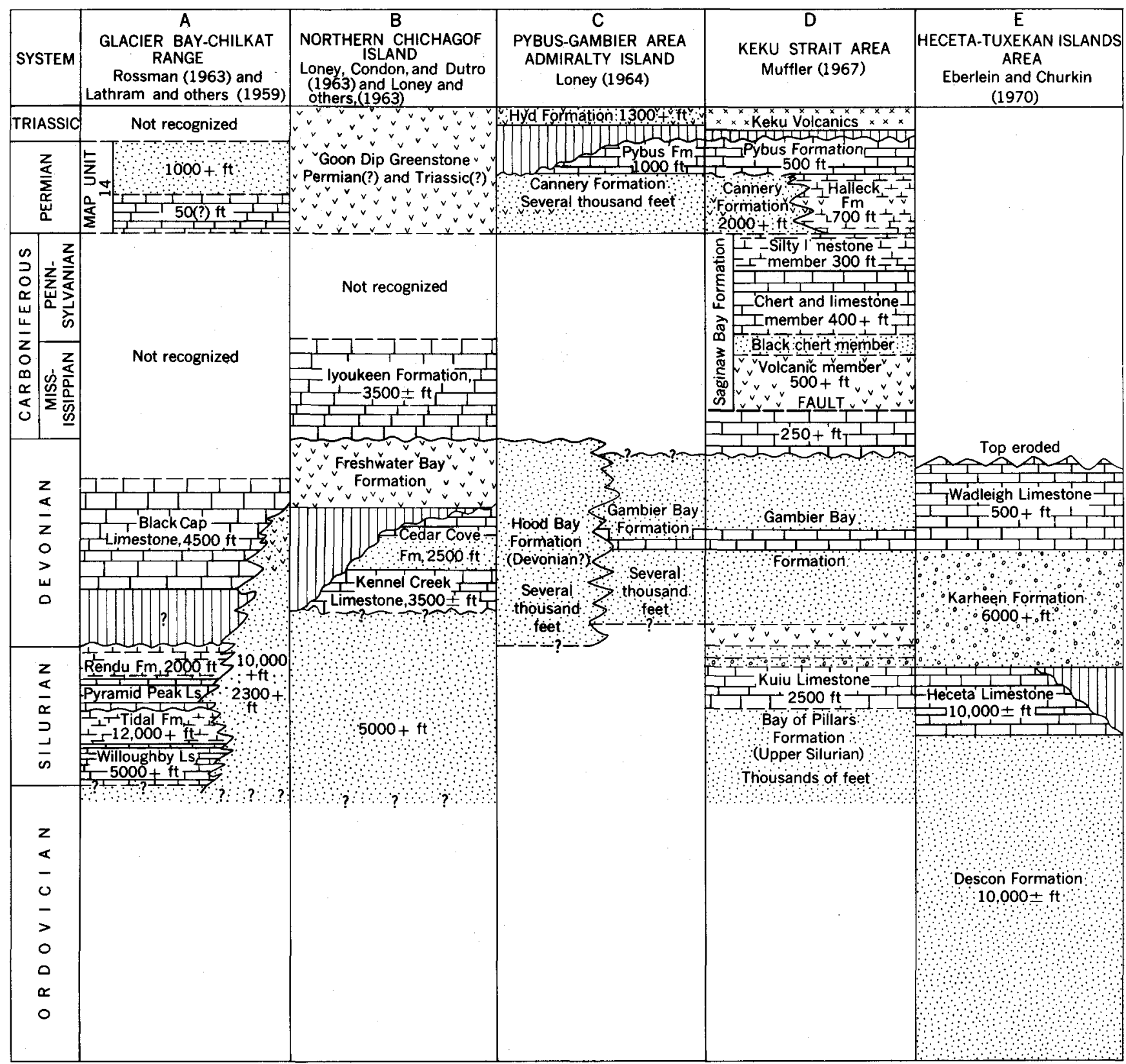

EXPLANATION PREDOMINANT LITHOLOGY

Graywacke, mud-
stone, and con-
glomerate; minor
pillow basalt, brec-
cia, and volcani-
claining mastic vol-
canic, sedimentary,
and plutonic rock
clasts and red sand-
stone; festoon
crossbedded, car-
bonate cemented;
minor platy lime-
stone




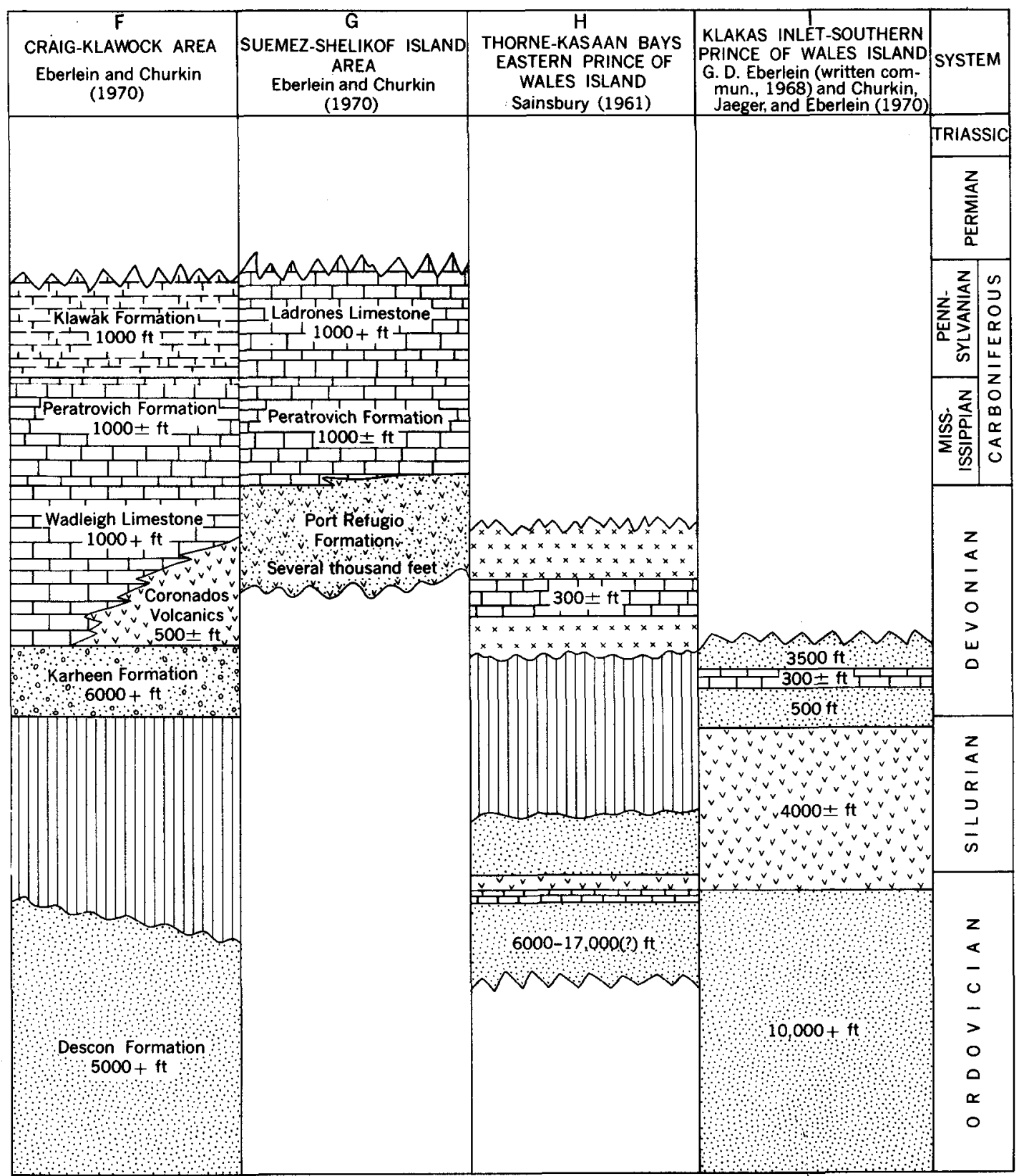

FIGURE 10.-Correlation chart of major rock types of Paleozoic age in southeastern Alaska showing rapid lateral changes in stratigraphy due to facies changes and, in some places, structural dislocations. See figure 9 for location of areas. 


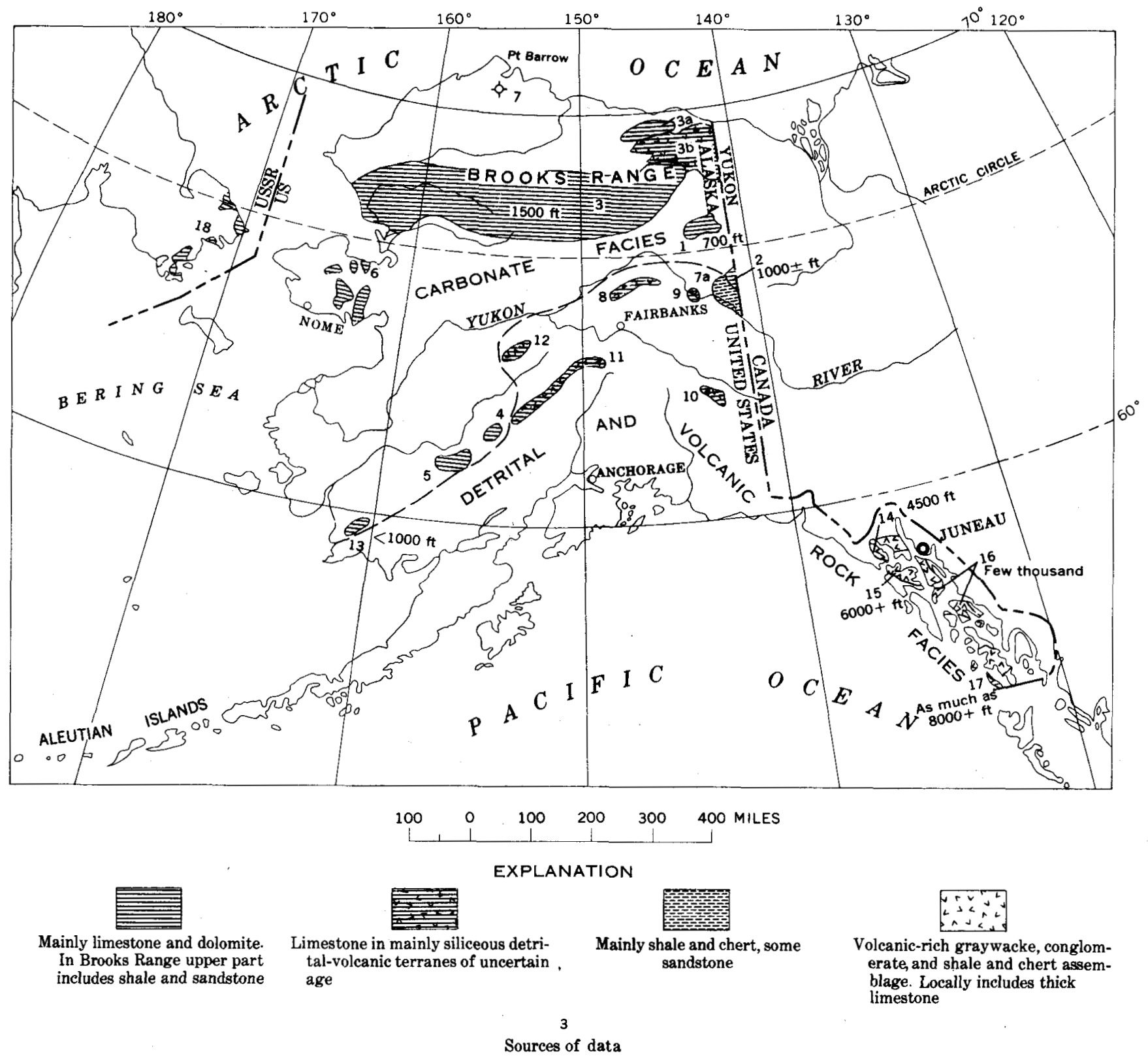

Figure 11.-Devonian rocks. Excludes coarse terrigenous rocks of Late Devonian and Mississippian age (Nation River, Kanayut, and Kekiktuk Formations) (cf. Gryc and others, 1967). 


\section{SOURCES OF DATA FOR FIGURE 11}

1. Porcupine River:

Salmontrout Limestone (Churkin and Brabb, 1967; Brosgé and others, 1966).

2. Jones Ridge area:

Thick limestone below McCann Hill Chert (Churkin and Brabb, 1965a).

3. West and Central Brooks Range:

Skajit Limestone, unnamed limestone and siltstone, and Hunt Fork Shale (Brosgé and others, 1962; Sable and Dutro, 1961; Bowsher and Dutro, 1957; Tailleur and others, 1967; Chapman and others, 1964).

3a. Sadlerochit-Shublik Mountains and vicinity:

Nanook Limestone and Katakturuk Dolomite (Dutro, 1970).

3b. Northeastern Brooks Range:

Neruokpuk Formation (Devonian(?) and older) (Brosgé and others, 1962; Sable, 1965; Reed, 1968; Reiser, 1970).

4. White Mountains:

(Sainsbury, 1965).

5. Central Kuskokwim River:

Upper part of Holitna Group (Cady and others, 1955).

6. Seward Peninsula:

(Revised after Smith and Eakin, 1911, and earlier workers).

7. Topagoruk test well:

500 feet + chert pebble conglomerate and shale (Collins, 1958).

7a. Charley River area:

Upper part of Road River Formation, McCann Hill Chert (Churkin and Brabb, 1965a; 1967).
8. Livengood area:

Upper part of Tolovana Limestone (Péwé and others, 1966; Church and Durfee, 1961).

9. Yukon River:

Woodchopper Volcanics (Mertie, 1930a; Brabb and Churkin, 1969).

10. East Alaska Range:

(Moffit, 1954).

11. Central Alaska Range:

Limestone overlying Tonzona Group (Brooks, 1911).

Limestone in vicinity of Farewell, Alaska (B. L. Reed, oral commun., 1968).

12. Upper Kuskokwim River:

(Revised after Smith and Eakin, 1911).

13. Lower Kuskokwim River:

(Hoare and Coonrad, 1961; Hoare, 1961).

14. Glacier Bay:

Black Cap Limestone (Rossman, 1963).

15. Chichagof Island:

Freshwater Bay Formation, Cedar Cove Formation, Kennel Creek Limestone (Loney and others, 1963).

16. Admiralty Island, Keku Strait:

Hood Bay Formation, Gambier Bay Formation (Loney, 1964; Muffler, 1967).

17. Prince of Wales Island:

Wadleigh Limestone, Coronados Volcanics, and Port Refugio Formation (Eberlein and Churkin, 1970).

18. Chukotsk Peninsula:

(Krasniy, 1966; Gnibidenko, 1969). 


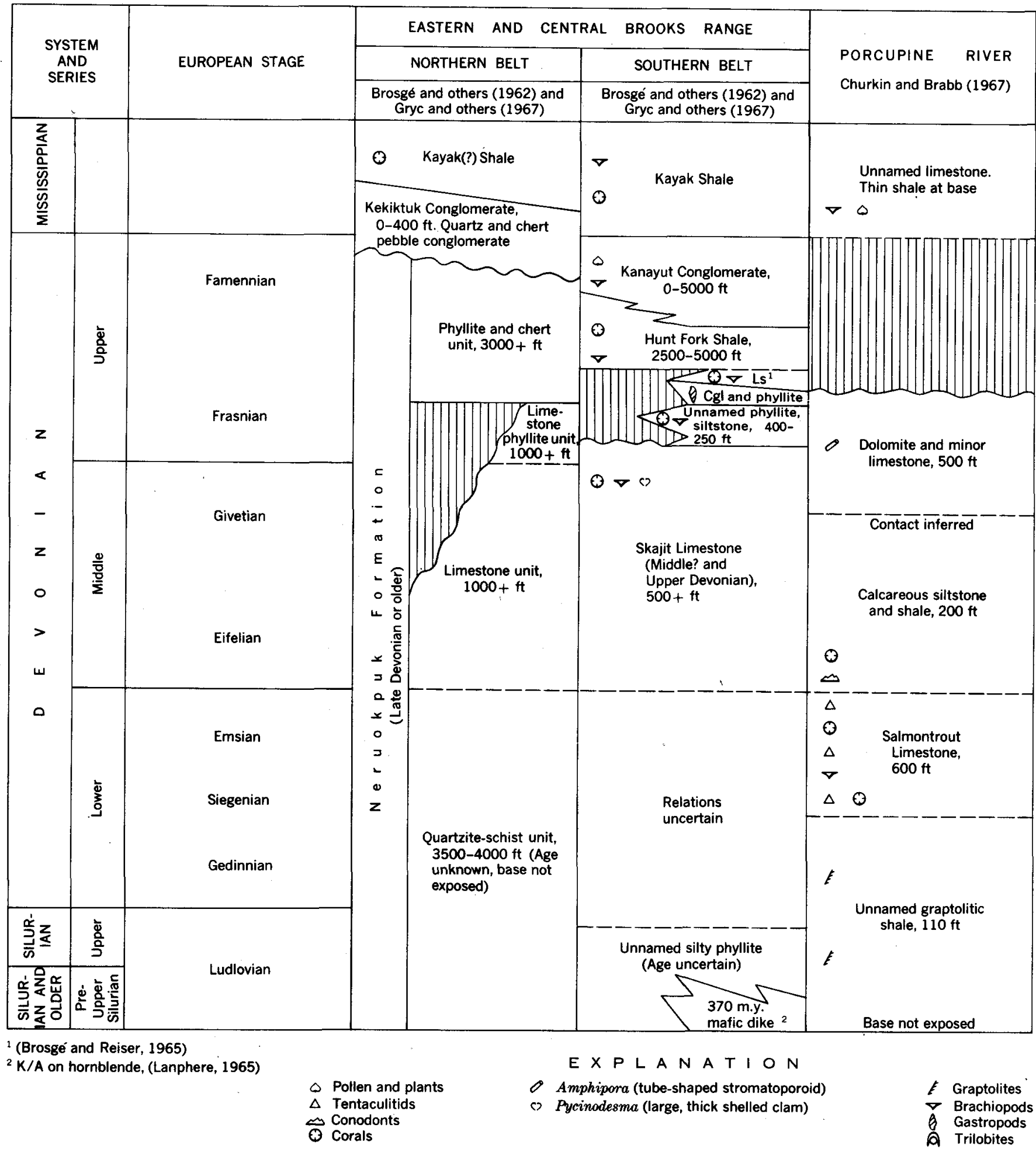




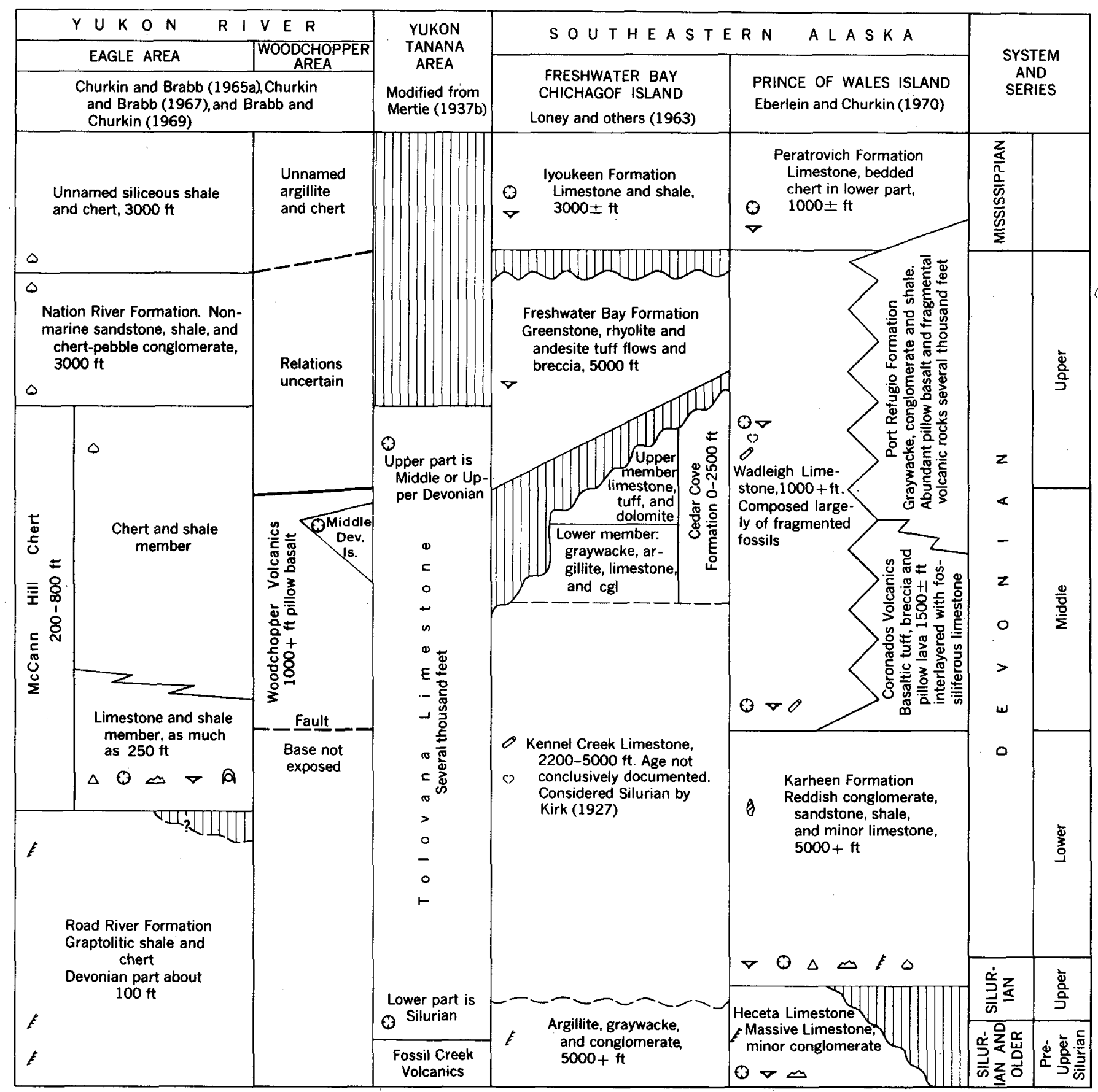

Figure 12.-Correlation chart of Devonian rocks. 


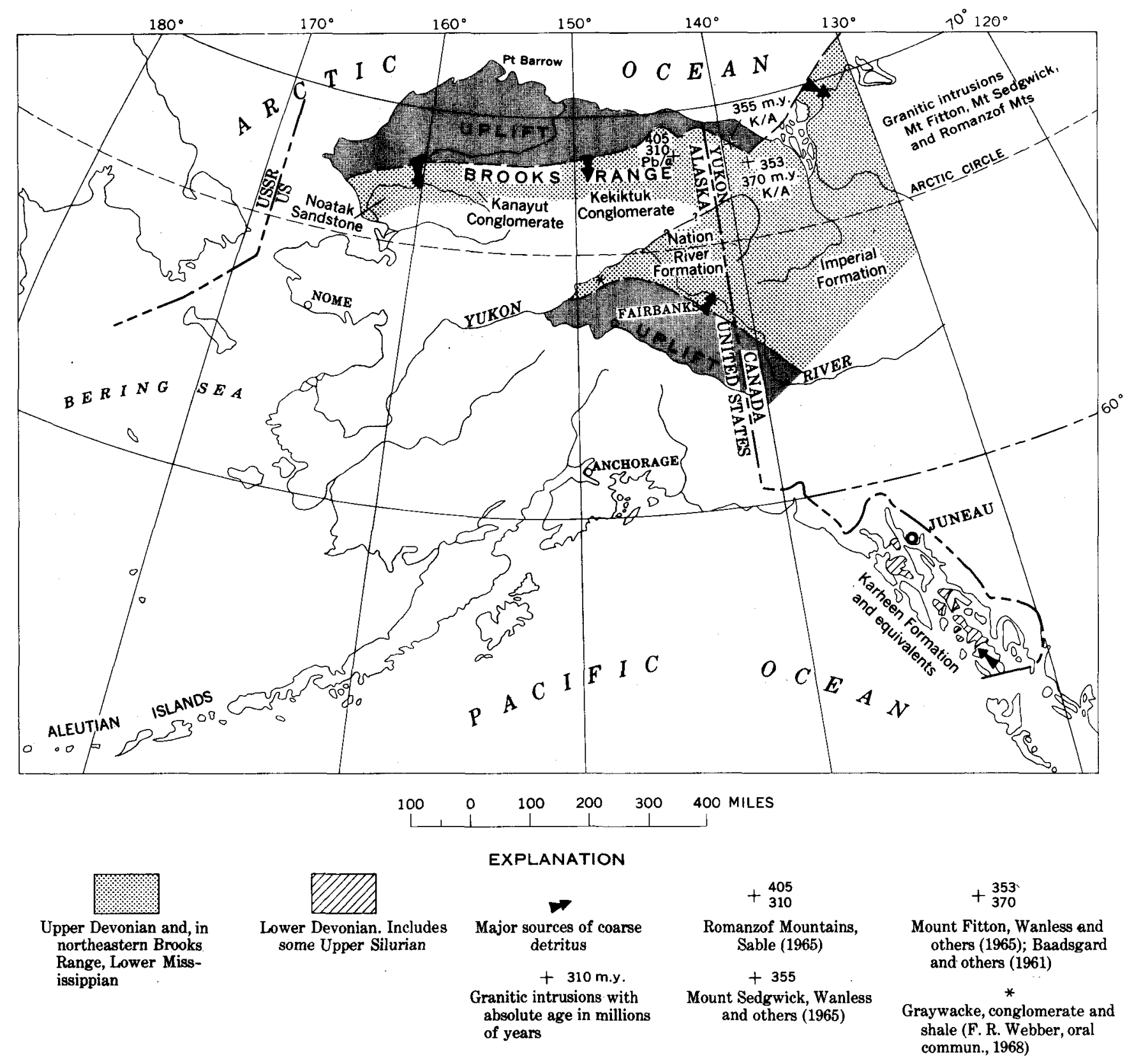

FIGURE 13.-Devonian coarse terrigenous rocks. Ineludes Mississippian Kekiktuk Conglomerate.

Much farther south and on the other side of the Yukon shelf, similar coarse clastic rocks (Nation River Formation) have a gradational contact with Devonian siliceous shale and chert below. However, clastic rocks similar to the Nation River Formation in the Livengood district lie with a marked unconformity on altered mafic volcanic rocks and serpentinites, and the basal conglomerate has fragments of these igneous rocks (Foster, 1967; F. R. Weber and Michael Churkin, Jr., field observations, 1968). These facts suggest that the Devonian clastic rocks in the interior of Alaska had sources separate from similar clastic rocks in the Brooks Range.

In southeastern Alaska there is similar evidence that plutonic activity and synorogenic uplift affected the Cordilleran geosyncline at various times during the Paleozoic (Lanphere and others, 1964; Brew and others, 1966; Eberlein and Churkin, 1968). Branched plant stems and spores are common in many of these clastic sediments and suggest a nonmarine or, more probably, a nearshore deltaic origin. 
Absolute age determinations of granitic intrusion in the northeastern Brooks Range and in other places around the edge of the Arctic Ocean basin indicate that plutonic activity was probably related to the same mid-Paleozoic uplifts that produced the wedge of Upper Devonian clastic sediments (Tailleur and others, 1967; Trettin, 1967; Churkin, 1969).

\section{CARBONIFEROUS ROCKS}

Fossils of Carboniferous age have been found in Alaska in different lithic sequences ranging from pure limestone to predominantly volcanic rocks (fig. 14). Although rocks of Mississippian age are widespread, rocks of Pennsylvanian age have only recently been positively identified, and their known distribution is limited.

The most continuous belt of Mississippian rocks in Alaska is along the Brooks Range. The Mississippian is represented there by the Lisburne Group, a 2,000- to 4,000-foot-thick, mainly carbonate section that has variable amounts of nodular chert and minor shale (Bowsher and Dutro, 1957; Brosgé and others, 1962; Armstrong, 1970a) (fig. 15). The Mississippian carbonate rocks are generally separated from the Upper Devonian conglomerate and sandstone by a 100- to 1,000-foot-thick unit of shale and argillite (Kayak Shale) that has sandstone in its lower part and limestone at its top (Tailleur and others, 1967; Brosgé and Tailleur, 1970). In exception, in the Sadlerochit Mountains in the northeast corner of Alaska, the Kayak Shale is locally absent or very thin, and Mississippian carbonate rocks rest unconformably on Devonian limestone and dolomite and, in places, on clastic rocks of Devonian(?) age (Reiser, 1970; Armstrong and others, 1970). Progressively younger carbonate rocks of the Lisburne overlap one another to the north, so that in the central Brooks Range they are Lower and Upper Mississippian and farther north, in the northeastern Brooks Range, the section ranges from Upper Mississippian at its base through the Middle Pennsylvanian at its top (cf. Brosgé and others, 1962; Armstrong and others, 1970). For the Lisburne Peninsula, at the west end of the Brooks Range, Campbell $(1967$, p. 6) also reports that the base of the Lisburne may transgress time, becoming progressively younger-Early Mississippian in the south to early Late Mississippian in the north. This fact suggests a northward migration of a nearby west-oriented shoreline through much of Carboniferous time.

Assuming that a shallow shelf existed north of the Brooks Range and that the Lisburne Group was deposited during a northward marine transgression onto this shelf, a series of facies maps has been drawn for various subdivisions of Carboniferous time by Armstrong and Mamet (1970). They also proposed the following depositional model of environments from south to north: starved basin (lime mud and chert), slope (lime mud), crinoid garden (crinoid and bryozoan-rich clean carbonate sandstone), oolite bank, back bank (bryozoan-crinoid sandstone with an increase in lime mud landward), and supratidal flat (lime mudstone and dolomite).

South of the Brooks Range, Carboniferous rocks are known from many small areas widely separated by Mesozoic rock cover or whose lateral connections are obscured by igneous or metamorphic activity.

In the Porcupine-Yukon Rivers area the Mississippian and probably some part of the Pennsylvanian (E. E. Brabb and Michael Churkin, Jr., unpub. data) are represented by a section of interbedded limestone and shale that forms the rhythmically banded section at Calico Bluff. A thin-bedded chert and shale unit of Devonian and Mississippian age (Ford Lake Shale) lies below the limestones of the Calico Bluff Formation and separates them from the underlying sandstone, conglomerate, and shale (Nation River Formation) of Late Devonian age (Brabb, 1969 ; Brabb and Churkin, 1969). Pre-Permian erosion in this area has removed much of the Carboniferous section (Churkin and Brabb, 1967, figs. $9,10)$.

In the northwestern part of the Yukon-Tanana region there is a poorly known sequence, mainly of noncalcareous sedimentary rocks including banded cherts (Livengood Chert), that, on the basis of a few fossil collections from rare limestones, had been assigned to the Mississippian (Mertie, 1937b). The occurrence of Oldhamia from Mertie's belt of "undifferentiated noncalcareous rocks of Mississippian age" suggests that at least some of the rocks previously considered Mississippian are probably Cambrian or older (Churkin and Brabb, 1965b; Michael Churkin, Jr., field data, 1968). More work is clearly necessary in this structurally complex region to determine the distribution and stratigraphy of Carboniferous rocks.

Siliceous detrital rocks and volcanic rocks southwest of the Yukon-Tanana region in the Kaiyuh Hills area and in Kuskokwim drainage (Mertie, 1937a; Cady and others, 1955) have been questionably assigned to the Mississippian on the basis of lithic 


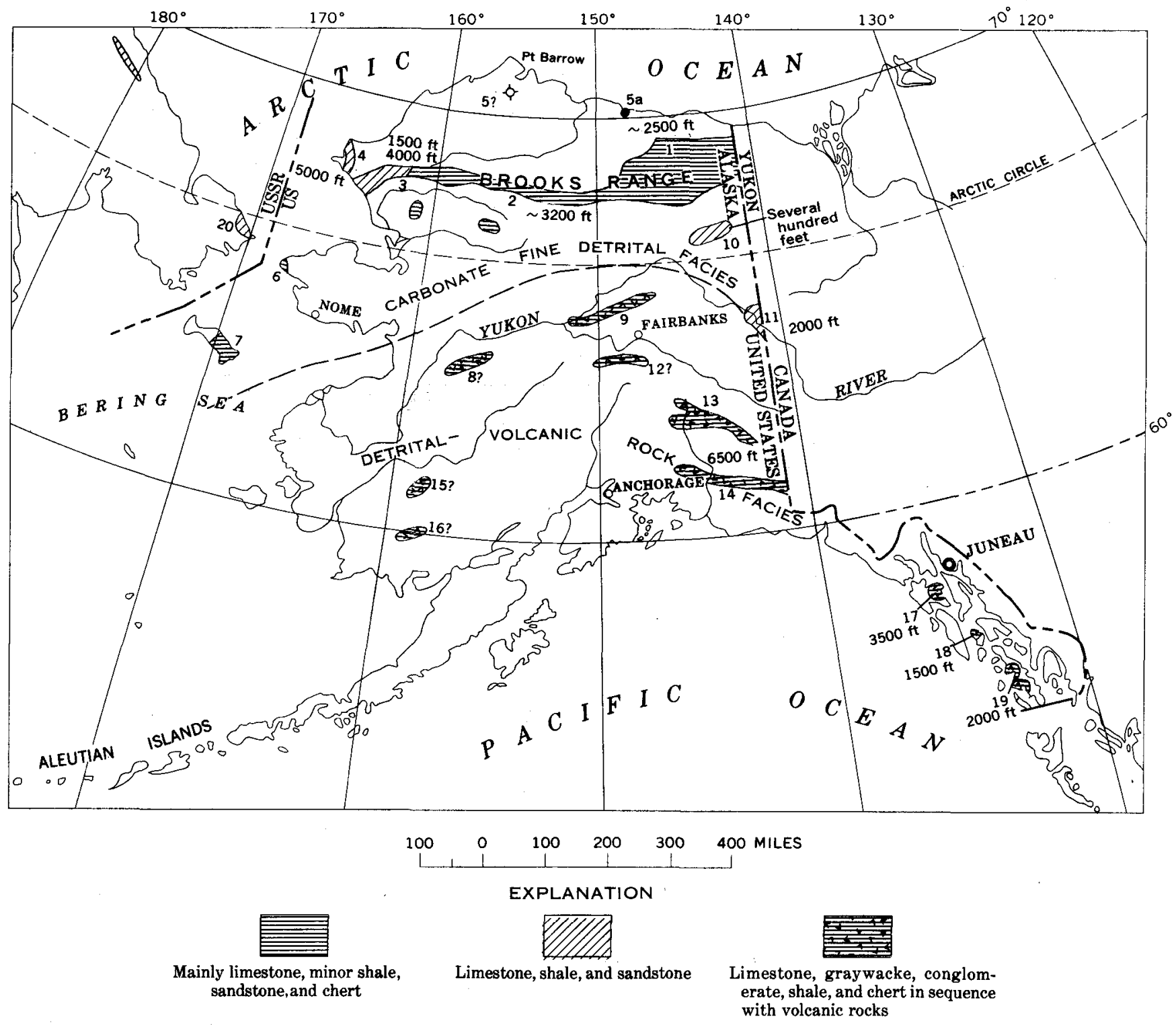

Figurm 14.-Carboniferous rocks of Alaska. See opposite page for sources of data.

similarity and their supposed stratigraphic position below fossiliferous Permian rocks. No conclusive evidence supporting a Carboniferous age for any rocks in this vast region is known to date.

During the Devonian this same lower YukonKuskokwim area was a southwestern extension of the predominantly carbonate sedimentation of eastcentral Alaska. However, in the Permian and presumably starting with the Carboniferous, southwestern Alaska as far north as Norton Sound was an area of siliceous detrital and volcanic rock accumulation (Cady and others, 1955, fig. 4). Farther west on St. Lawrence Island, there is a section at least 1,000 feet thick of limestone and cherty limestone that closely resembles, both lithically and faunally, the Mississippian of the Brooks Range (Patton and Dutro, 1969). Furthermore, the presence on St. Lawrence Island of Devonian dolomite below the Mississippian limestone and a section of Triassic and possibly Permian siltstone, shale, and chert above it further indicate a close correlation of this section with those in the Brooks Range. Coralbearing limestone of probable Mississippian age has been reported from the vicinity of Cape Prince of Wales at the east tip of the Seward Peninsula (Steidtmann and Cathcart, 1922). Sainsbury (oral commun., 1970) verified the presence of probable Lisburne limestone there, but, according to him, the 


\section{SOURCES OF DATA FOR FIGURE 14}

1. Lake Peters:

Kayak Shale, Lisburne Group (Brosgé and others, 1962).

2. Shainin Lake:

Kayak Shale, Lisburne Group (Bowsher and Dutro, 1957; Patton and Tailleur, 1964).

3. DeLong Mountains:

Lisburne Group (Sable and Dutro, 1961).

4. Lisburne Peninsula:

Lisburne Group (Campbell, 1967).

5. Topagoruk test well:

Red beds of uncertain age (Collins, 1958).

5a. Prudhoe Bay oil field:

Kayak Formation and Lisburne Group (Rickwood, 1970).

6. Cape Mountain:

(Steidmann and Cathcart, 1922; Sainsbury, oral commun., 1969).

7. St. Lawrence Island:

Lisburne(?) limestone underlain by Devonian dolomite (Patton and Dutro, 1969).

8. Kaiyuh Hills :

Nonfossiliferous volcanic rock (Mertie, 1937a).

9. Livengood-Yukon River area:

Livengood Chert (Mertie, 1937b).

10. Porcupine River:

(Brosgé and others, 1966).

11. Eagle area:

Calico Bluff Formation, upper part of Ford Lake Shale (Brabb and Churkin, 1967).

12. Central Alaska Range:

Totatlanika Schist (Péwé and others, 1966).

13. Eastern Alaska Range:

Rainbow Mountain sequence (Rowett, 1969).

Chisna Formation (Moffit, 1954).

14. Chitina Valley:

Strelna Formation and Klutina Group (Moffit, 1938).

15. Kuskokwim River:

Lower nonfossiliferous part of Gemuk Group (Cady and others, 1955).

16. Nushagak District:

Nonfossiliferous siliceous rocks below Permian limestone (Mertie, 1938).

17. Chichagof Island:

Iyoukeen Formation (Loney and others, 1963).

18. Kuiu Strait area :

Saginaw Bay Formation (Muffler, 1967).

- 19. Craig area:

Peratrovich Formation, Klawak Formation, Ladrones Limestone (Eberlein and Churkin, 1970).

20. Northeast U.S.S.R.:

(Krasniy, 1966).

limestone is a structurally isolated and largely recrystallized mass difficult to correlate. Thus, in widely separated areas along the far western edge of Alaska north of Norton Sound, one finds a predominantly limestone facies that rims the volcanicrich siliceous detrital facies of the lower YukonKuskokwim region.
In the eastern Alaska Range a variety of rocks have been questionably assigned to the Mississippian because they seem to be structurally below fossiliferous Permian rocks and lithically resemble rocks (Strelna Formation) that contain Mississippian fossils in a parallel belt nearly 100 miles farther south. These sequences of questionable Mississippian age consist of sandstone, argillaceous rock, and conglomerate that are interlayered with prominent volcaniclastic rocks and mafic lava flows (Moffit, 1954). Limestone is relatively rare in the section, and all rocks have been altered to various degrees by low-grade regional metamorphism. Southwest of Fairbanks on the north side of the Alaska Range, the tabulate coral Syringopora, found in the Totatlanika Schist, suggests a post-Ordovician, possibly Mississippian, age (Wahrhaftig, 1968). According to Wahrhaftig, the schist is derived mainly from volcanic rocks. Minor interbedded fossiliferous limestone lenses indicate a marine environment.

South of the Alaska Range, the Strelna Formation, originally dated as Mississippian by corals and brachiopods, is exposed along the Chitina Valley which separates the Wrangell Mountains from the Chugach Mountains farther south (Moffit, 1938). The Strelna Formation is a complex of greenstone (bedded basaltic lavas and tuffs) interstratified with argillite, greenschist, chert, and minor fossiliferous marble that is estimated to be in excess of 6,500 feet thick; neither its top nor base is known. Work in progress by E. M. MacKevett, Jr., suggests that the formation has Permian brachiopods in its type section. Furthermore, the general stratigraphy of the Strelna, although it is more metamorphosed, resembles parts of the Permian section nearby (E. M. MacKevett, Jr., oral commun., 1969). Somewhat higher grade quartz-mica schists and amphibolite schists (the Klutina Group and the Dadina Schist), west and north (?) of the Chitina Valley, are correlated with the Strelna Formation (Moffit, 1938).

In several parts of the Alexander Archipelago of southeastern Alaska there are volcanic-rich sequences similar to those in the Chitina Valley. These sequences are the most southerly exposures of Carboniferous rocks in Alaska and are especially important in that the rocks are generally not altered and contain very abundant shelly fossils that permit detailed correlations in an area of rapid facies changes. Within southeastern Alaska the northern exposures of Mississippian strata on Chichagof Island are predominantly limestone (fig. 10). Farther south, in the Keku Strait area, the Mississippian and Pennsylvanian section is limestone with volcanic and 


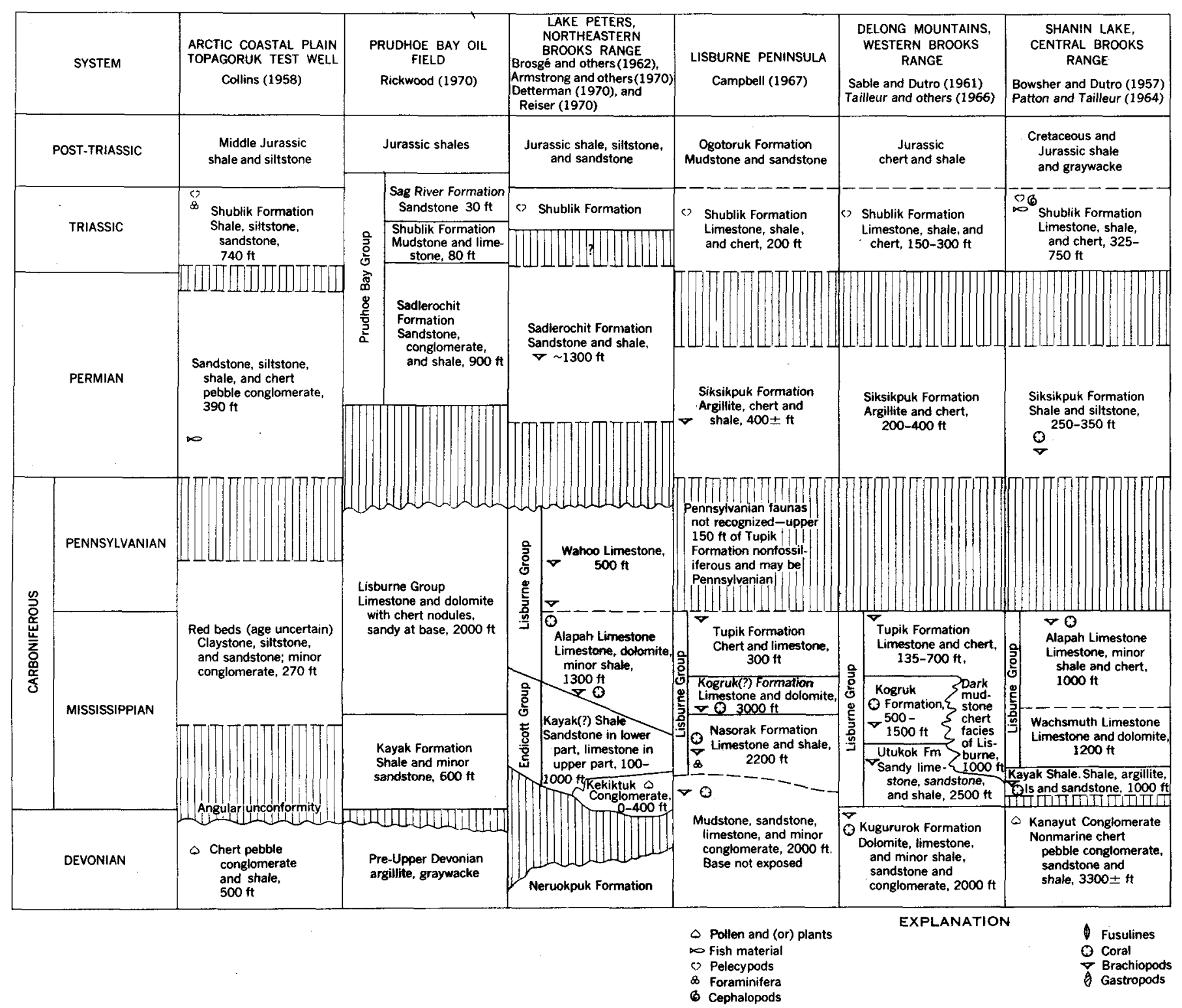

Figure 15.-Correlation chart of Carboniferous and Permian rocks.

chert members in its lower part (Muffler, 1967). Still farther south, in the Craig-Klawak and Suemez-Shelikof Island areas, the Mississippian and Pennsylvanian are represented by a section of impure limestone that has chert in its lower part (Eberlein and Churkin, 1970; Armstrong, 1970b).

Pennsylvanian rocks have not been widely recognized in Alaska. In the Brooks Range, Pennsylva- nian faunas have been recognized only from the upper parts of the Lisburne Group (Brosgé and others, 1962 ; Armstrong and Mamet, 1970). Recent mapping in the Yukon River area, combined with preliminary paleontologic studies of fossils from the upper Calico Bluff Formation, suggest that there are a few places in east-central Alaska where Pennsylvanian rocks occur. However, most of the Pennsyl- 


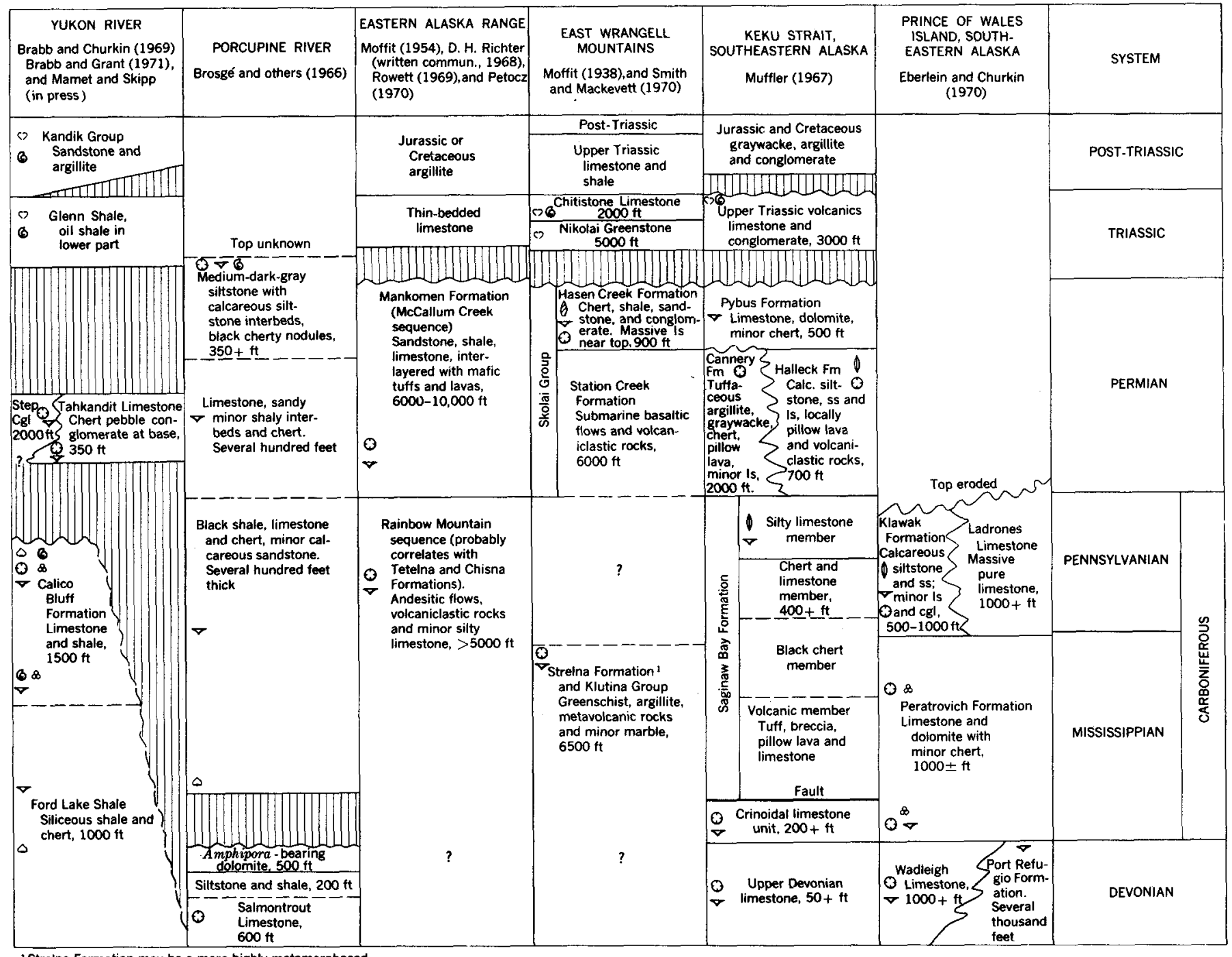

I Strelna Formation may be a more highly metamorphosed

equivalent of Permian(?) and Permian Skolai Group

Figure 15.-Correlation chart of Carboniferous and Permian rocks-Continued.

vanian and a large part of the Mississippian in eastcentral Alaska have been removed by erosion, and Permian strata in many places rest unconformably on rocks of Devonian age (Brabb and Churkin, 1967).

Farther south, in the Rainbow Mountain area of the Alaska Range, a thick succession (about 7,000 ft thick) of volcanic graywacke, tuff, siltstone, and limestone of Pennsylvania age has been recently recognized (Rowett, 1969).

In contrast to most of Alaska where Pennsylvanian fossils are difficult to identify or are missing, Pennsylvanian rocks in southeastern Alaska are recognized by rich shelly faunas including an abundance of fusulinids (Dutro and Douglass, 1961; R. C. Douglass, written commun., 1968). The Pennsylvanian rocks in southeastern Alaska occur on Kuiu Island (Dutro and Douglass, 1961) and in two areas on the west side of Prince of Wales Island (Eberlein and Churkin, 1970). They are predominantly limestone with varying amounts of nodular chert and contain some chert and quartz detritus.

\section{PERMIAN ROCKS}

Permian rocks are known from virtually all the areas in Alaska that contain older Paleozoic rocks (fig. 16). The Seward Peninsula, where Permian rocks have not been reported to date, is a noteworthy exception. In general, Permian sedimentation throughout southeastern Alaska (Muffler, 1967; Brew, 1968), the Wrangell Mountains (Smith and MacKevett, 1970), and the eastern Alaska Range (D. H. Richter, written commun., 1968; Rowett, 1969; Petocz, 1970) closely paralleled the pattern that developed in the Carboniferous, deposition of sequences rich in volcaniclastic and volcanic rocks. In addition, good Permian faunas are known from 

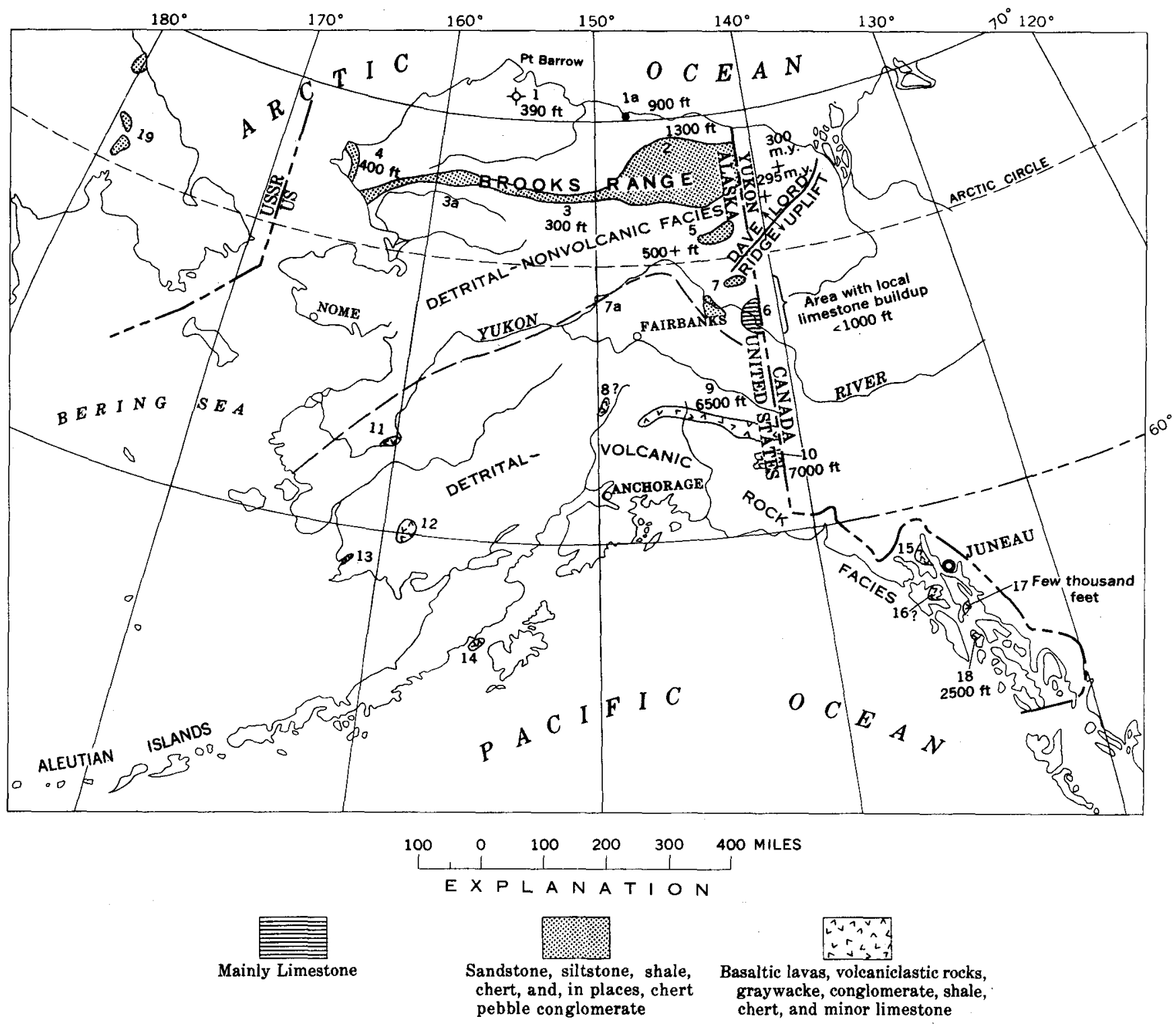

Figure 16.-Permian rocks of Alaska. See opposite page for sources of data.

the lower Yukon-Kuskokwim area of southwestern Alaska where fossiliferous limestone 500-1,000 feet thick grades stratigraphically upward into mafic lavas and tuffs over 4,500 feet thick (Mertie, 1938; Smith, 1939, p. 33). In the Goodnews Bay district, on the coast of the Bering Sea, Permian brachiopods were first reported (Smith, 1939, p. 33) from limestone associated with red and black slates. Subsequent mapping there indicates that the Permian limestone grades laterally into greenstone (Hoare and Coonrad, 1961).

Permian limestone in close proximity to basaltic breccias, agglomerates, and flows is known from a tiny islet off Cape Kekurnoi on the southeast side of the Alaska Peninsula opposite Kodiak Island (Hanson, 1957). This isolated exposure of Permian rock is separated from the nearest Paleozoic rocks (in the Kuskokwim area) by more than two hundred miles of Mesozoic and Quaternary cover.

Even more isolated than the Permian Limestone at Cape Kekurnoi is the report of Pennsylvanian or Permian plants from Adak Island in the middle of the Aleutian Island arc (Coats, 1956). The plant material consists of about a dozen well-preserved leaf impressions in a fine-grained volcanic sandstone. Coats considered the sandstone as part of a predominantly basaltic unit that is similar in appearance to the Tertiary and Quaternary volcanic 


\section{SOURCES OF DATA FOR FIGURE 16}

1. Topagoruk test well:

Includes some chert pebble conglomerate (Collins, 1958).

1a. Prudhoe Bay oil field:

Lower part of Sadlerochit Formation (Rickwood, 1970).

2. Lake Peters:

Sadlerochit Formation (Brosgé and others, 1962; Detterman, 1970).

3. Shainin Lake:

Siksikpuk Formation (Bowsher and Dutro, 1957; Patton and Tailleur, 1964).

3a. Nuka Ridge:

Upper part of Nuka Formation, arkosic sandstone and limestone (Tailleur and Sable, 1963).

4. Lisburne Peninsula:

Siksikpuk Formation (Campbell, 1967).

5. Porcupine River:

(Brosgé and others, 1966).

6. Eagle area:

Tahkandit Limestone (Brabb and Churkin, 1969).

7. Yukon River:

Step Conglomerate (Brabb and Churkin, 1969).

7a. West edge of Yukon Flats:

Rampart Group of questionable Permian age (Brosgé and others, 1969).

8. Susitna River area :

(Ross, 1933).

9. Eastern Alaska Range:

Mankomen Formation (Moffit, 1954; D. H. Richter, written commun., 1968; Rowett, 1969).

10. East Wrangell Mountains:

Skolai Group of questionable Permian and Permian age (Moffit, 1938; Smith and MacKevett, 1970).

11. Lower Yukon River:

Permian fossil-bearing limestone $(500-1,000 \mathrm{ft})$ overlain conformably by 4,500 feet of greenstone (Smith, 1939).

12. Nushagak area:

Permian limestone overlain conformably by tuff (Mertie, 1938).

13. Goodnews Bay district:

Permian limestone interlayered and grades into finegrained silicéous sedimentary rocks and volcanic rocks (Smith, 1939; Hoare, 1961).

14. Cape Kekurnoi area:

Permian limestone associated with volcanic rocks (Hanson, 1957).

15. Chilkat Range:

Limestone and graywacke (Lathram and others, 1959).

16. Chichagof Island: Goon Dip Greenstone of Permian(?) and Triassic(?) age (Loney and others, 1963).

17. Admiralty Island:

Cannery Formation and Pybus Formation (Loney, 1964 ; Muffler, 1967.

18. Keku Strait area:

Cannery, Halleck, and Pybus Formations (Muffler, 1967).

19. Chukotka, Northeast U.S.S.R.:

(Krasniy, 1966). rocks that form most of the Aleutian Islands. In an attempt to explain this unique occurrence of Paleozoic rock in the Aleutians, the plant locality on Adak Island was studied, and the sandstone matrix surrounding the plants was found to contain abundant pollen and some pelecypods that are diagnostic of Tertiary age (Scholl and others, 1970). It is concluded that these plants, although remarkably similary to Paleozoic species, are Tertiary.

In the Iliamna Lake-Kamishak Bay area of the upper Alaska Peninsula, on the Kenai Peninsula, and on Kodiak Island, fossiliferous Upper Triassic limestone conformably overlies mafic volcanic flows, breccias, and tuffs that have been questionably assigned by various authors to the Permian and Triassic (Burk, 1965). In these areas, sequences of slate, graywacke, chert, and volcanic rock of unknown age seem to be older than the predominantly volcanic sequences underneath the Triassic limestone. Considered still older, probably Paleozoic or Precambrian, is a metamorphic complex of marble, schist, gneiss, and quartzite. Large granitic batholiths that have reconstituted much of the rock in the area are known to be Jurassic, and some are as young as Late Cretaceous (Reed and Lanphere, 1969). Thus, some of the more metamorphosed rocks, presumed to be the oldest, could be as young as early Mesozoic. The single exposure of fossiliferous Permian rocks at Cape Kekurnoi suggests that detrital-volcanic rock facies of southeastern Alaska extended during the late Paleozoic into what is now part of the Alaska Peninsula.

Permian rocks are widely, distributed in the Wrangell Mountains and adjacent parts of Canada (Moffit, 1938; Smith and MacKevett, 1970). The Permian in this area consists of a slightly metamorphosed sequence (Skolai Group) more than 8,000 feet thick of submarine basaltic flows, breccias, and tuffs that are interbedded with volcaniclastic sediments, shale, and chert (Smith and MacKevett, 1970). Cliff-forming massive limestone near the top of the sequence consists mainly of fragmented shelly fossils that indicate an Early Permian age. Age data are lacking on the underlying volcanic flows and volcaniclastic rocks. The base of the sequence has not yet been recognized, and the more highly metamorphosed and deformed rocks (Strelna Formation) in the area that originally were thought to be Mississippian in age are now believed to be more highly metamorphosed equivalents of the Skolai Group (E. M. MacKevett, Jr., written commun., 1970). Locally, the Skolai Group is overlain disconformably by Middle Triassic strata and, more extensively, by the 
Nikolai Greenstone of late Middle and (or) early Late Triassic age (Smith and MacKevett, 1970).

Farther north, in the upper Copper River valley and eastern Alaska Range, there is a Permian section characterized by an abundance of volcanic rocks interbedded with calcareous sediments (Mendenhall, 1905; Moffit, 1954). In the vicinity of Mankomen Lake (type locality of the Mankomen Formation), the stratigraphic section, mainly argillaceous and sandy sediments about 5,000 feet thick, includes a series of massive limestone lenses as much as 500 feet thick (D. H. Richter, written commun., 1969). According to Richter, these rocks are conformably underlain by $200-1,700$ feet of fine- to coarsegrained volcaniclastic rocks that contain Permian corals and fusulinids, and these rocks, in turn, are underlain by andesitic lavas of Pennsylvanian(?) age. Overlying the Mankomen Formation is a section, about 5,000 feet thick, of amygdaloidal basalt that has Permian brachiopods in massive reeflike limestones. Stratigraphically higher are Triassic and Jurassic or Cretaceous strata that rest on the Permian lavas with angular unconformity.

Farther west, in the Rainbow Mountain-Delta River area of the Alaska Range, the Permian section is characterized by volcanic and marine sedimentary strata rich in volcaniclastic detritus (Rowett, 1969; Petocz, 1970). As in the Permian sections near Mankomen Lake farther east, richly fossiliferous limestones occur in the upper part of the section, and the lower part is mainly volcaniclastic rock interlayered with argillaceous and graywacke sediments. Detailed stratigraphic studies in this part of the Alaska Range, coupled with studies of coral faunas (Rowett, 1969) and of fusulinid faunas (Petocz, 1970), make this section an important reference point for Permian correlations not only in Alaska but with sections that have similar boreal faunas in the U.S.S.R., Canada, Greenland, and Spitsbergen.

In the Nation River area north of the Alaska Range, the Permian is represented by relatively pure, massive limestone-the Tahkandit Limestone. The Tahkandit is only about 350 feet thick and has glauconitic sandstone and chert-pebble conglomerate at its base where it unconformably overlies the Nation River Formation of Late Devonian age (Brabb and Churkin, 1967; Brabb and Grant, 1971). East, west, and north of its type area near the mouth of Nation River, the Tahkandit brachiopod fauna is found in limy interbeds that are part of a predominantly detrital facies of chert-pebble conglomerate, sandstone, and siltstone-the Step Con- glomerate (Brabb and Churkin, 1969). Permian brachiopods are also known from limestone beds in predominantly argillite sections exposed in the upper Black River, some 50 miles north of the type Tahkandit (E. E. Brabb, oral commun., 1968).

Still farther north, on the Porcupine River, several hundred feet of sandy productoid brachiopodrich limestone and minor shale and chert interbeds of Carboniferous age is overlain by medium-darkgray siltstone containing rare corals, branchiopods, and cephalopods of Permian age (Brosgé and others, 1966).

At the west edge of the Yukon Flats, an assemblage of basaltic flows, tuffs, and breccias including smaller amounts of interbedded chert, shale, and sandstone-the Rampart Group-had been assigned to the Mississippian on the basis of a few bryozoa from a lens of limestone questionably within the volcanic sequence or possibly from a somewhat older horizon (Mertie, 1937b, p. 126-127). Examination of new collections, as well as the old collections, shows that this limestone bed is within the volcanic sequence and is more likely to be Permian than Mississippian (Brosgé and others, 1969). The limestone itself is composed largely of pelecypod prisms like those of Inoceramus and, in this respect, resembles similar prisms in Permian limestone beds in east-central Alaska (Tahkandit Limestone) and in southwestern Alaska (Gemuk Group). Hornblende from gabbro that seems to intrude the Rampart volcanic rocks has an age of $205 \pm 6 \mathrm{~m} . \mathrm{y}$. (Triassic) based on potassium-argon isotope dating (Lanphere, in Brosgé and others, 1969).

Igneous rocks similar to those of the Rampart Group but with a smaller proportion of associated sedimentary rocks are found farther east in the Crazy Mountains and in the vicinity of Circle along the south edge of the Yukon Flats. These mainly fine-grained igneous rocks of basaltic composition were named by Mertie (1930) as the Circle Volcanics and correlated on the basis of lithic similarity with the Rampart Group about 175 miles farther west (Mertie, 1937, p. 127-128). A potassium-argon isotope date on hornblende from an intrusive (?) rock within the Circle Volcanics is 220 m.y. (M. A. Lanphere, written commun., 1968). This is a Triassic date that closely corresponds to the 205-m.y. age of gabbro that seems to intrude Rampart volvanic rocks (Brosgé and others, 1969). Aeromagnetic surveys indicate that igneous rocks underlie much of the Yukon Flats and suggest that the Circle Volcanics continues west with little interruption and possibly connects up with similar rocks 
of the Rampart Group (Brosgé and others, 1970). More recent work in this area indicates that the Circle Volcanics in its type area along the Yukon River and farther west in the Crazy Mountains does not have textural or structural characteristics that are exclusively volcanic (Michael Churkin, Jr., unpub. field data, 1968). The Circle Volcanics, like the volcanics of the Rampart Group, is reported to have many siliceous sedimentary rocks interlayered with it (Mertie, 1937b). However, an examination of the best exposures of Circle Volcanics in contact with sedimentary rocks indicates that the so-called volcanic rocks have very fine grained chilled margins and that the sedimentary rocks, mainly argillites and quartzitic sandstones, next to them are recrystalized so that argillaceous sedimentary rocks are spotted slates (Michael Churkin, Jr., unpub. field data, 1968). Furthermore, the Circle Volcanics in detail has crosscutting relations with the sedimentary rocks, and fragments of the sedimentary rocks have been incorporated into the intrusive rocks, in places making up large selvages. Away from these contacts, the Circle Volcanics consists of diabases or coarse-grained gabbros that are generally porphyritic and, in places, have mineralogic layering. Taking all these features into acount, I believe that the Circle Volcanics is mainly not lava flows but intrusive rocks of probable Triassic age. Whatever the age of the Circle Volcanics, late Paleozoic or Triassic, its intrusive origin explains the absence of volcanic detritus in the surrounding sedimentary rocks of this span of geologic time.

Permian rocks are widely distributed along the Brooks Range (figs. 15, 16) and are generally represented by only a few hundred feet of argillaceous rocks, chert, sandstone, and conglomerate of the Siksikpuk and the lower part of the Sadlerochit Formations (Brosgé and others, 1962; Bowsher and Dutro, 1957; Patton and Tailleur, 1964; Campbell, 1967; Detterman, 1970). The Sadlerochit Formation is the main reservoir rock in the Prudhoe Bay oil field (Rickwood, 1970; fig. 15). An erosional hiatus representing much of Pennsylvanian time separates these Permian clastic rocks from the Lisburne carbonate rocks, but the time gap is younger and may decrease towards the front of the northeastern Brooks Range where the Lisburne ranges upward into the Middle Pennsylvanian (Armstrong and others, 1970). All these Permian clastic deposits, in turn, are overlain disconformably by the thin sequence of oil shale, limestone, and sandstone of the Shublik Formation of Triassic age (Brosgé and others, 1962; Detterman, 1970).
A notable exception to this general stratigraphic sequence of upper Paleozoic rocks is the enigmatic section of Mississippian and Permian arkosic sandstone and limestone of the Nuka Ridge area on the north slope of the DeLong Mountains (Tailleur and Sable, 1963 ; Tailleur and Brosgé, 1970).

Up to this point, the paper has summarized the stratigraphic data available on Precambrian and Paleozoic rocks in Alaska. The rest of the paper attempts to interpret their tectonic significance and their role in the structural evolution of Alaska.

\section{INTERPRETATION OF STRATIGRAPHIC DATA-TECTONIC FRAMEWORK OF SEDIMENTATION \\ PRECAMBRIAN ROCKS}

The Tindir Group of east-central Alaska, the only definite Precambrian rocks known in Alaska, is at the northwest end of a long belt of late Precambrian strata that runs south across Yukon Territory and British Columbia into the northern Rocky Mountains of Alberta, Washington, and Idaho. The better exposed sections of these rocks measure tens of thousands of feet. The great thickness of sedimentary rocks (including minor basaltic lavas) distributed in this long belt indicates a major cycle of sedimentation of geosynclinal proportions.

No regional unconformities have thus far been found within the Tindir Group, and it seems to be accordantly overlain by fossiliferous Cambrian rocks. Farther to the southeast, the top of the late Precambrian Windermere Series, the Rapitan Group, and the Belt Supergroup are all marked by unconformities. Over large areas these unconformities are ill defined, but their existence has been proved by regional mapping (Yates and others, 1966). In parts of southern Yukon Territory, a major unconformity within the Proterozoic also separates the Belt Supergroup from the overlying Windermere Series (Gabrielse, 1967), and the Windermere, in turn, is progressively removed by erosion below the Cambrian. Paleontologic studies of stromatolites from the Tindir may further define the age of the Tindir and permit closer correlation with the Belt Supergroup farther south on the one hand and, on the other, with the stromatolite-rich upper Precambrian rocks of the Siberian Platform farther west.

The base of the Tindir is not known, but rare boulders of granitic rock and gneiss in the Tindir suggest that an earlier Precambrian igneous and metamorphic basement is not distant. Uplifts of metamorphosed rock in the central interior of Alaska, particularly the Birch Creek Schist, have 
been postulated as representing the earlier Precambrian. Potassium-argon isotope dating, however, has generally not verified their Precambrian age. Preliminary rubidium-strontium isotope dating of schists in the same area and in the Seward Peninsula has also produced a number of Paleozoic and Precambrian dates, and there now seems to be more hope of unraveling the metamorphic history of Alaska.

\section{LOWER PALEOZOIC ROCKS}

Cambrian through Middle Devonian rocks in eastcentral Alaska are part of a cycle of nearly continuous sedimentation (Churkin and Brabb, 1967 ; fig. 1). Elsewhere in the interior and northern parts of Alaska, Devonian and, in places, Ordovician and Silurian rocks have been reported from a number of widely separated areas. Unfortunately, most of these stratigraphic successions are structurally complex and incomplete. Cambrian rocks, although known with certainty only from east-central and northeastern Alaska, probably occur in the Alaska Range (Michael Churkin, Jr., and B. L. Reed, field data, 1969) and in the Seward Peninsula (Sainsbury, 1969a). Coarse clastic deposits of Late Devonian age in east-central Alaska and of Late Devonian and Mississippian age in the Brooks Range indicate indirectly sources of argillite and chert of probable early Paleozoic age within the Cordilleran geosyncline to the south and in the ancestral Brooks geosyncline to the north, respectively (fig. 12). Isotope age determinations of granitic rocks around the margin of the Canada Basin (fig. 13) indicate a period of intrusion that is probably related to the same middle Paleozoic orogeny that produced these Late Devonian clastic wedge deposits and that marks the end of the early Paleozoic sedimentation cycle.

\section{CORDILLERAN GEOSYNCLINE}

In southeastern Alaska where lower Paleozoic rocks are exposed along the present continental margin, sedimentation was nearly continuous from the Lower Ordovician, the oldest rocks in the area, into the Upper Silurian (fig. 10). The high proportion of volcanic and volcaniclastic rocks together with conglomerates of mixed composition, rapid facies changes, and local disconformities in this section imply rapid sedimentation in a tectonically active area. In the Early Devonian a widespread sequence of terrigenous clastic rocks including red beds (upper part of Karheen Formation of Eberlein and Churkin, 1970) marks a significant break in sedi- mentation within the southeastern Alaska part of the Cordilleran geosyncline (Ovenshine and others, 1969; fig. 13). This same conglomerate has been assumed to be a tillite and has been cited as evidence of Paleozoic glaciation (Kirk, 1918). The latest work, however, does not support a glacial origin.

Thin to very thick lenticular biogenic limestones of Silurian and Devonian age occur in the section of the Cordilleran geosyncline exposed in southeastern Alaska (fig. 10). The high proportion of reef-building coral and stromatoporoid fragments in these biogenic limestones suggests that nearby reefs were periodically fragmented to provide the enormous volume of fossil material in the limestones. I have seen, in the Willoughby Limestone of Silurian age in Glacier Bay and in Devonian limestone at several places on the west coast of Prince of Wales Island, small patch reefs with coral and stromatoporoid skeletons preserved encrusting each other in growth position. In most of these limestones a nearshore shallow-water environment of deposition is indicated not only by the shelly fauna but also by stromatolitic algae, intraformational breccias, and oolitic limestone. In some of the limestone, thick lenses of breccia and conglomerate rich in volcanic fragments suggest development of the limestone around volcanic centers and other prominences on the sea floor.

Lower Paleozoic rocks of the coarse detrital, volcanic-rich facies of southeastern Alaska are known farther south in the San Juan Islands and in the northern Cascade Mountains of Washington (Danner, 1966) and in the Klamath Mountains of northern California (Irwin, 1966; Churkin and Langenheim, 1960). From southeastern Alaska this part of the Cordilleran geosyncline, rich in volcanic rocks, probably continued westward and may have connected with similar rocks of the Paleozoic geosyncline in the Koryak Mountains of Northeast U.S.S.R. (Bogdanov and Tilman, 1964; Belyi, 1964; Egiazarov and others, 1965). In south-central and southwestern Alaska, poorly known and structurally complex terranes of detrital sedimentary and volcanic rocks that contain some fossiliferous limestones are part of this Cordilleran geosynclinal belt. These widely separated sequences probably belong to a stratigraphic belt that more or less rimmed the northern Pacific Basin and that now is largely buried by younger rocks or obscured by regional metamorphism and plutonic activity mainly of Mesozoic age (fig. 1; Churkin, 1969).

A thick carbonate-quartzite sequence (the Millard miogeosynclinal belt of Kay, 1947) should theoretically lie north of the volcanic-rich eugeosynclinal 
belt of southeastern Alaska. Except for the thick carbonate rocks in the Kuskokwim River region of southwestern Alaska (Cady and others, 1955; Sainsbury, 1965) and possibly in the Seward Peninsula (Sainsbury, 1969a), thick sequences of pure carbonate rock are virtually unknown in central Alaska (fig. 1). In parts of the Alaska Range, however, limestone sections, especially those of Devonian age, have been reported (Moffit, 1938; Brooks, 1911; B. L. Reed, oral commun., 1968). These isolated limestone masses seem to be surrounded by predominantly terrigenous rocks and may represent biogenic limestone buildups in a predominantly clastic section as do the similar limestones in southeastern Alaska.

In the Eagle area of east-central Alaska, on the northern edge of the Cordilleran geosyncline Paleozoic sedimentation started with the deposition of thin Cambrian limestone conformable on upper Precambrian strata. Rapid changes in lithofacies, the presence of oolitic intraformational boulder and edgewise conglomerate, and rich tribolite, brachiopod, and archeocyathid faunas suggest a shallowwater turbulent marine environment for this area during most of the Cambrian (Brabb, 1967).

In contrast to the generally coarsely detrital rocks in southeastern Alaska, near Eagle there is a thinly and rhythmically interbedded black chert and siliceous shale lithofacies that has thin interbeds and partings of graptolitic shale (Churkin and Brabb, 1965a). The Early Ordovician through Early Devonian, a span of about 100 million years, seems to be represented here by only 900 feet of section without any sign of a significant stratigraphic break. This unusually thin stratigraphic section probably represents a long period of slow, deepwater sedimentation. These siliceous rocks continue east into northern Yukon Territory where they thicken in the Richardson basin (Jackson and Lenz, 1962). A similar graptolitic shale section that again spans most of the Ordovician and the Lower Silurian in less than a 1,000 feet of section has recently been found in the Alaska Range southeast of Farewell (Michael Churkin, Jr., B. L. Reed, and J. W. Kerr, field data, 1969 and 1970). Similar, but in places reportedly much thicker, sequences of chert and graptolitic shale, which in addition contain quartzite and minor amounts of pillow basalt, characterize the Frazer eugeosynclinal belt of the central Great Basin that lies between the volcanic-rich coarsely detrital rocks in the Klamath Mountains and the predominantly carbonate-quartzite rocks of the miogeosyncline in the eastern Great Basin (Roberts and others, 1958; Churkin and Kay, 1967).

\section{YUKON SHELF AND RICHARDSON BASIN}

The predominantly limestone and dolomite facies of the Silurian and the Devonian cover large areas across the central part of Alaska (east-central Alaska, part of southwestern Alaska and the Seward Peninsula), and extend north into parts of the Brooks Range. These rocks, especially in east-central Alaska where they have been most thoroughly studied, seem to be thin shelf carbonate deposits that lie north of the predominantly coarse detrital and volcanic rocks of the Cordilleran geosyncline in southern Alaska. Siliceous shale sequences along the Upper Yukon River and in the Alaska Range seem to represent a considerably thinner, but nearly complete, stratigraphic transition from the shelf carbonates on the north to the coarse detrital rocks with abundant interlayered volcanic rocks in the south.

In the early Paleozoic, and especially during the deposition of the Road River Formation (Lower Ordovician to Lower Devonian), the site of the Richardson Mountains in northern Yukon Territory was an area of accumulation of thick graptolitic shale, bedded chert, and argillaceous limestone (Jackson and Lenz, 1962). The area of Road River sedimentation apparently progressively spread from the Richardson Mountains in Early Ordovician time to include most of Yukon Territory by the end of the Silurian (Norford, 1964). At the same time, however, thin shelf limestones interfingering with thin sequences of graptolitic shale were forming laterally over the rest of northern Yukon Territory and eastern Alaska (Churkin and Brabb, 1967). Thus, the Richardson Mountains basin during the Paleozoic was not, as Jeletzky (1962) has already shown, a northern extension of the Cordilleran geosyncline (Martin, 1961), but was a narrow basin that developed within the Yukon shelf (Churkin and Brabb, 1967).

In conclusion, during the early Paleozoic, the Yukon shelf in east-central Alaska, and possibly extending farther west across the center of Alaska, seems to have separated two distinct geosynclinal belts, the Cordilleran geosyncline in the south from the ancestral Brooks geosyncline on the north (fig. 1).

\section{ANCESTRAL BROOKS GEOSYNCLINE}

In the Brooks Range and on the North Slope, few rocks have been firmly dated as pre-Middle Devonian (pre-Skajit Limestone). However, in the southern Brooks Range and, more certainly, in the northeastern Brooks Range, there are thick sequences of weakly metamorphosed, predominantly siliceous 
rocks of pre-Late Devonian age (Brosgé, 1960; Brosgé and Tailleur, 1970). These rocks include the Neruopuk Formation in the northeastern Brooks Range, a thick sequence mainly of detrital sedimentary rocks (Reed, 1968) but including mafic lavas, intrusive rocks, and volcaniclastic sedimentary rocks (Reiser, 1970). Similar rocks with rare Devonian fossils and including mafic dikes of Paleozoic age form a narrow belt along the axis of the Brooks Range (Brosgé and Reiser, 1964; 1965). Argillites beneath Triassic rocks at the bottom of a borehole at Point Barrow (Payne and others, 1951) may belong to the belt of weakly metamorphosed siliceous rocks exposed in the northeastern Brooks Range. High magnetic anomalies along the Arctic Slope of Alaska suggest that igneous rock masses like those in the northeastern Brooks Range form a large part of the basement below the Mesozoic cover farther west (Payne and others, 1951). In general, these rocks in the Brooks Range and farther north appear to be thicker and are more detrital than the predominantly carbonate rocks of early Paleozoic age in east-central Alaska. This fact suggests a northward transition from a central Alaskan carbonate shelf into a now largely buried and partially destroyed circum-Canada Basin geosyncline (Churkin, 1969). More recently, the discovery of Cambrian trilobites (J. T. Dutro, Jr., W. P. Brosgé, and H. N. Reiser, written commun. and unpub. data, 1971), recognition of substantial amounts of mafic volcanic rocks, and dating of Silurian granitic rocks support the idea that a lower Paleozoic geosyncline deformed in the middle Paleozoic forms much of the basement of the Brooks Range.

In contrast, in the Shublik and Sadlerochit Mountains adjacent to the Arctic Coastal Plain, there is 6,500 feet of limestone and dolomite below limestone of Carboniferous age (Dutro, 1970). Devonian fossils occur in the upper 200 feet of this sequence, but its lower part may represent much of the earlier Paleozoic as well. The lateral extent of these carbonates is unknown, and thus their regional significance is unclear. The carbonate rocks may represent a major facies change as the Arctic coast is approached or a localized area of carbonate in a predominantly terrigenous section.

If parts of the Neruopuk Formation in the northern part of the Brooks Range and in the British Mountains of northern Yukon Territory are equivalent to rocks of the northern (eugeosynclinal) part of the Franklinian geosyncline of the Canadian Arctic Islands much farther east, then the Skajit Limestone and perhaps the Hunt Fork Shale (both of Devonian age and exposed in a belt south of the Neruopuk) could be considered as western equivalents of the carbonate and shale belt (miogeosyncline) of the southern part of the Franklinian geosyncline.

The thick chert-rich detrital rocks of Late Devonian and in part Early Mississippian age in the Brooks Range are thought to have been derived from a northern source (Brosgé and others, 1962). Farther east, in northern Yukon and Northwest Territories, nonmarine sandstone and shale (Imperial Formation) pass southeastward into marine equivalents (Douglas and others, 1963). A similar belt of Upper Devonian detrital rocks, apparently derived from the northern part of the Franklinian geosyncline, occurs in the Canadian Arctic Archipelago as far east as Ellesmere Island (Thorsteinsson and Tozer, 1960; Trettin, 1967). In Chukotka and Wrangell Island, on the opposite side of Alaska, there are similar Upper Devonian(?) conglomerates (Bogdanov and Tilman, 1964; Tilman, 1964). Some geologists (Shatsky, 1935 ; Eardley, 1948; Payne and others, 1951) have thought that in Late Devonian time widespread uplift in what is now the Arctic Ocean exposed a Precambrian shield which provided coarse sediment to nearby parts of Canada, Alaska, and Siberia. However, a shield source seems unlikely because of the mainly chert, quartz, and argillite detritus, coarse grain size, and wedgelike shape of the sedimentary body and its apparently nonmarine character. Instead, the highly deformed siliceous rocks of the Neruokpuk Formation and similar rocks of pre-Late Devonian age in other parts of the Brooks Range and in boreholes along the Arctic coast more likely were the sources of the detritus (Churkin, 1969). Absolute age determinations of granitic rocks around the margin of the Canada Basin part of the Arctic Ocean indicate that the intrusion of these rocks probably was related to the same middle Paleozoic period of deformation and uplift that produced the wedge of Upper Devonian clastic deposits (Tailleur and others, 1967; Trettin, 1967; Churkin, 1969). Elsewhere in North America, at about the same time, clastic wedges 
were derived from uplifts in the Cordilleran (Roberts and others, 1958; Gabrielse and Wheeler, 1961) and Appalachian (Kay, 1947) geosynclines. Late Devonian time was thus one of widespread orogeny that marks major breaks in the early Paleozoic geosynclinal cycles.

\section{UPPER PALEOZOIC ROCKS}

CORDILLERAN GEOSYNCLINE

The Carboniferous and Permian rocks of southeastern Alaska closely parallel the earlier Paleozoic sequences mainly of detrital rocks interlayered with submarine lavas. Fortunately, subordinate amounts of highly fossiliferous limestone are generally present and provide a means of correlation. In contrast to the earlier Paleozoic pattern, good Carboniferous and Permian sections similar to those in southeastern Alaska are also known in the Wrangell Mountains and the eastern Alaska Range. Furthermore, detrital and volcanic rock sequences of late Paleozoic age cover a large area of southwestern Alaska that in the earlier Paleozoic received only carbonate rock (Cady and others, 1955).

The isolated exposure of upper Paleozoic rocks at Cape Kekurnoi suggests that the detrital volcanic belt along the Pacific margin in southeastern Alaska continues west. These upper Paleozoic rocks, associated with metamorphic rock complexes that may represent still older Paleozoic rocks, form the basement for the thick Mesozoic and, in places, Cenozoic sedimentary deposits of the Alaska Peninsula (Burk, 1965). The Devonian and Mississippian pure dolomite-limestone section on St. Lawrence Island provides a northern limit to any extension of this belt across the Bering Shelf (fig. 17).

The northern boundary of the detrital-volcanic rock facies that is here for the most part equated with the northern limit of the Cordilleran geosyncline is located on the Alaska mainland somewhere between the Seward Peninsula and the lower reaches of the Yukon. Farther east this boundary, although probably complicated by major faults, approximately follows the Yukon River (fig. 17). Along the northwest edge of the Yukon-Tanana Upland, in the center of Alaska, are the northernmost rocks of the upper Paleozoic detrital-volcanic rock facies. Because of complex structure and scarcity of diagnostic fossils, the stratigraphy here is poorly known. It seems that the Carboniferous and perhaps the
Permian is represented by a noncalcareous sedimentary sequence mainly of fine-grained detrital rocks with abundant chert. Thus, these upper Paleozoic rocks like nearby lower Paleozoic rocks, represent a facies transitional into the purer carbonate rock sections farther east and north.

\section{YUKON SHELF}

Northeast of the Yukon-Tanana area and across the Tintina trench, Carboniferous and Permian nonvolcanic rocks are known to underlie a large part of the Yukon-Porcupine Rivers area. The Carboniferous section here consists of thinly interbedded limestone, shale, and chert. Deep erosion below the base of the overlying Permian strata has, however, removed all but a small area of Carboniferous rocks in the vicinity of Calico Bluff. The Permian is a predominantly detrital facies of chert-pebble conglomerate, sandstone, siltstone, and argillaceous rocks. Locally, limy interbeds occur and these limestones may reach thicknesses of several hundred feet (Tahkandit Limestone).

The conglomerate and sandstone of Permian age along the Yukon River, like the clastic rocks of Late Devonian age, are made up mostly of chert and argillaceous rock fragments. Part of the detritus in the basal conglomerate of the Permian, where it unconformably lies on rocks of Late Devonian age, is derived from reworking the older conglomerate, sandstone, and argillite (Brabb and Churkin, 1967). Similar chert-pebble conglomerate of questionable Permian age occurs farther north on Dave Lord Ridge just south of where the Porcupine River crosses the international boundary. As is true of the clastic rocks of Late Devonian age, the Permian detrital sediments in the interior of Alaska came from uplifts of siliceous sequences that bordered the area.

BROOKS BASIN AND RELATED BASINS

In the Brooks Range the Carboniferous sections are mainly limestone and dolomite with variable amounts of interbedded shale and chert (Brosgé and others, 1962). The considerably thinner Permian rocks are predominantly fine-grained detrital rocks and chert. The base of the Lisburne Group becomes progressively younger and more detrital into the northern parts of the Brooks Range. This northward transgression, plus the fact that the unconformably overlying Permian sandstones and 


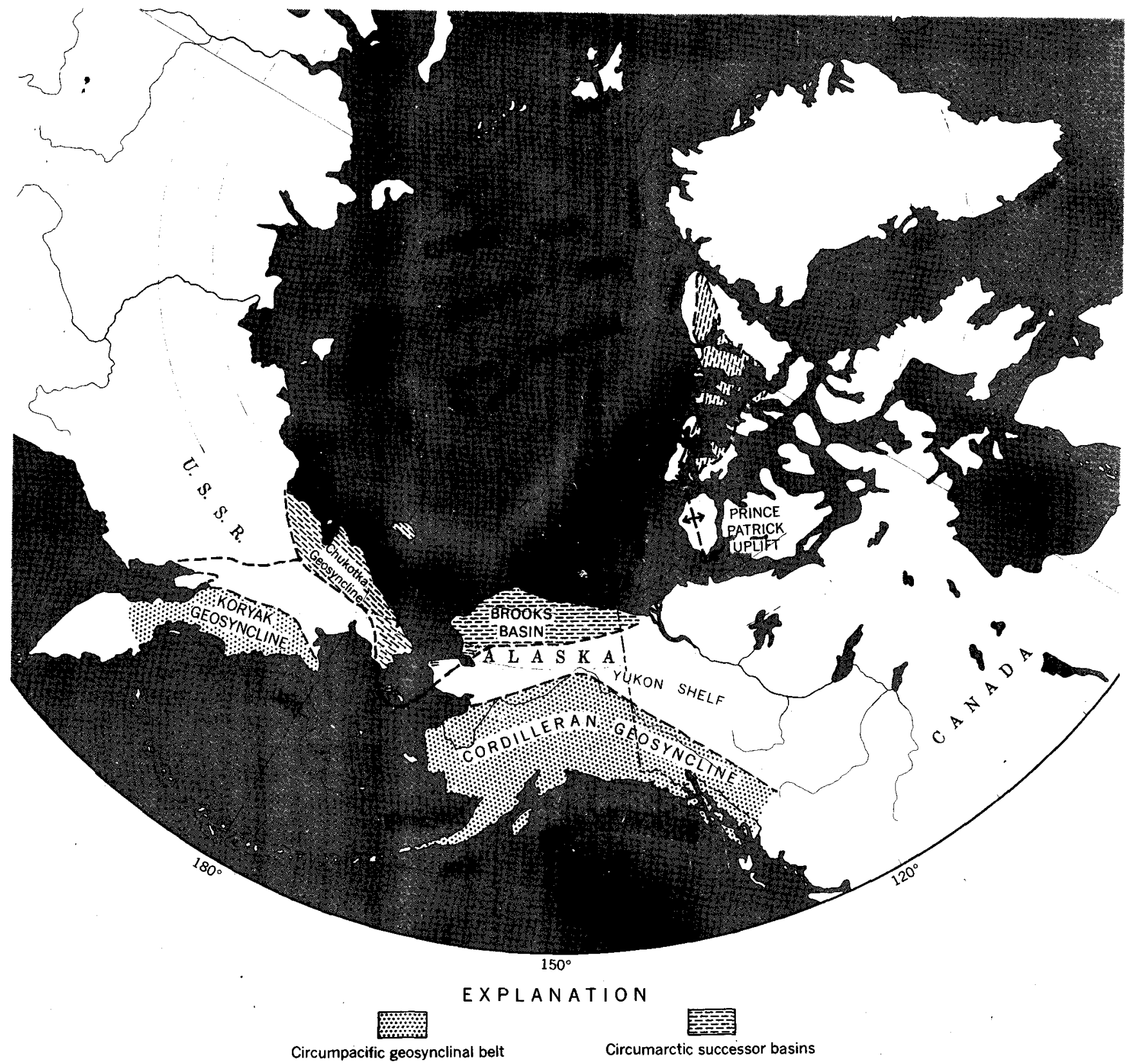

Frgure 17.-Tectonic framework of Carboniferous and Permian sedimentation.

conglomerates are also rich in chert detritus, suggest that in the late Paleozoic a source area existed north of the Brooks Range (Brosgé and others, 1962; Detterman, 1970). This source area may reflect renewed uplift of the ancestral Brooks geosynclinal belt that was providing sediment during the Late Devonian and Mississippian (Churkin, 1969).

\section{MESOZOIC AND CENOZOIC TECTONIC EVENTS} AFFECTING PALEOZOIC ROCKS

The geologic conditions that prevailed throughout Paleozoic time in the southern half of Alaska seem to have continued on into early Mesozoic time. Triassic rocks in southeastern and southern Alaska, although separated in places from Paleozoic rocks by an unconformity, are characterized by basaltic submarine lavas and associated volcaniclastic rocks in a mainly detrital sedimentary sequence that continued the geosynclinal pattern established in the Paleozoic (Brew and others, 1966). Thin argillaceous limestones occur locally, but massive purer limestone and dolomite sequences like those in the Paleozoic are very rare. The only good example of a close parallel to the earlier Paleozoic carbonate 
development in southern and southeastern Alaska is the 2,000-foot-thick section of nearly pure limestone and dolomite (Chitistone and Nizina Limestones) in the Wrangell Mountains (Moffit, 1938; Armstrong and others, 1969). In the Kuskokwim region, the Gemuk Group, ranging in age from Carboniferous to Early Cretaceous (Hoare and Coonrad, 1961), is composed of siltstone, chert, mafic volcanic rocks, thin limestone, and graywacke that seem to be a westward continuation of the stratigraphy in southeastern Alaska.

In the interior and northern parts of Alaska where Triassic rocks are known, they generally rest on Permian rocks with approximate structural conformity (Lathram, 1965; Detterman, 1970; Brabb and Churkin, 1969). The Triassic rocks of northern Alaska, composed of thin sequences of argillaceous sediments interbedded with minor limestone and chert, parallel closely the Permian sedimentation pattern in the same area (Detterman, 1970).

In the Jurassic, and in places starting in the Cretaceous, began the development of a new pattern of high tectonic activity that lasted throughout most of the Mesozoic and locally continued through the Cenozoic. Where once the broad stratigraphic belts of the Paleozoic geosynclines and shelf existed, the rocks were now deformed into a series of troughs and basins that were separated by uplifts (Payne, 1955); Gates and Gryc, 1963). The sediments that filled the depressions were dominantly detrital and were largely derived from nearby highlands composed of Paleozoic and Precambrian rocks (fig. 18). It was during these episodes of orogeny that vast tracts of Precambrian and Paleozoic rocks in the interior of Alaska and farther south in the Alaska and Coast Ranges were severely deformed, altered by metamorphism, and in places ultimately granitized. The general pattern of basins and uplifts in the Mesozoic, and to a lesser degree in the Tertiary, tends to be arcuate and follows the trend of the Paleozoic stratigraphic belts (Payne, 1955). This parallelism shows the strong influence of the Precambrian and Paleozoic basement in controlling the tectonic features developed in the Mesozoic and Cenozoic.

Most of the post-Paleozoic sedimentary rocks of Alaska are largely impure sandstones of the graywacke type interbedded with dark argillaceous rocks and conglomerate. Furthermore, many of the postPaleozoic sediments contain far more detrital feldspar than the rocks on which they lie. Notable examples are the Cretaceous strata of east-central Alaska where the amount of potassium feldspar detritus increases markedly in rocks of post-middle Early Cretaceous age (Brabb, 1969); this fact suggests that the earlier Mesozoic intrusive rocks in the nearby Yukon-Tanana Upland (Wasserburg and others, 1963) were unroofed by late Mesozoic time. Another example is along the northern border of Matanuska basin where granitic intrusive rocks cut Lower Jurassic strata and furnished debris to form Upper Jurassic conglomerates (Gates and Gryc, 1963 , p. 273). Thus, the batholithic intrusions and their subsequent uplift, like the differentiation of Alaska into positive and negative areas, began in the Jurassic and continued intermittently through the late Mesozoic and into the Tertiary (cf. Reed and Lanphere, 1969).

At the end of the Cretaceous and the beginning of the Tertiary, widespread orogenic movements affected large areas of Alaska. It was during this time that the thick late Mesozoic sequences of the Colville basin were intensely folded and thrust faulted northward (Gates and Gryc, 1963).

Alaska was virtually emergent by the end of the Cretaceous and has remained so up to the present. In exception, Tertiary basins of marine deposition developed along the southern and northern borders of Alaska (fig. 18). The most significant of these was along the Gulf of Alaska where Eocene through Pliocene, mostly marine strata total at least 25,000 feet in thickness (Stoneley, 1967). In the interior of Alaska at various times during the Tertiary, local deformation formed small basins that were quickly filled by nonmarine coal-bearing sequences of claystone, sandstone, and conglomerate. Several of these continental deposits developed in narrow trenches along major transcurrent fault zones-the Tintina (Brabb and Churkin, 1969) and the Kaltag fault zones (Patton and Hoare, 1968).

Deformation that produced uplift and erosion over much of Alaska during the Tertiary apparently intensified at the close of the Tertiary and continued into the Quaternary. This orogenic activity has resulted in the strong uplift that produced the present mountain ranges.

Along with the deformation, the Cenozoic orogenic events produced widely scattered terrestrial volcanic rocks and granitic intrusives. Tertiary granites, although not so extensive as those of the Mesozoic, are known from most of the geologic provinces of Alaska, but they are rare or absent in east-central Alaska, the Brooks Range, and the Arctic Coastal Plain. The Aleutian volcanic arc and the associated oceanic trench are prominent features of this high tectonic activity that started in the Cenozoic and 


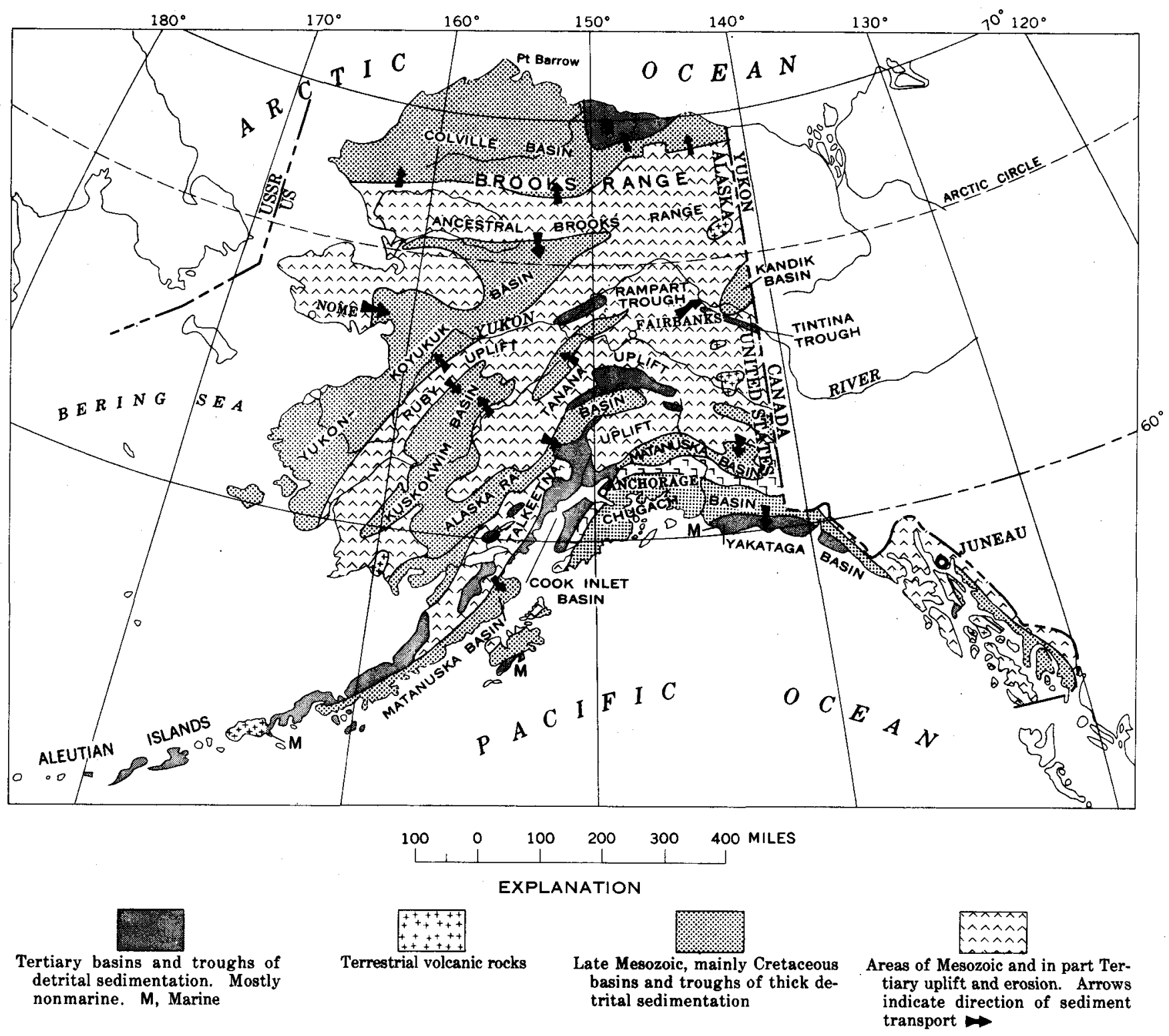

Figure 18.-Late Mesozoic and Tertiary tectonic features.

continues into the present (Coats, 1956; Burk, 1965).

\section{MAJOR STRUCTURAL FEATURES OF PALEOZOIC ROCKS}

Alaska experienced such extensive penetrative folding, faulting, metamorphism, and intrusion during multiple episodes of Mesozoic and Cenozoic deformation that, as in other far more intensely studied parts of the North American Cordillera, any Paleozoic or older structures are generally very difficult to recognize. The structures that will receive attention here are first of all the major foldbelts that indirectly reflect the trends and configurations of the older tectonic elements, such as basins, troughs, and stable areas that controlled the Paleozoic sedimentation patterns. Secondly, some of the large-scale faults that may have displaced the Paleozoic stratigraphic belts and juxtaposed different rock types will be discussed.

\section{FOLDBELTS OF ALASKA AND THEIR EXTENSIONS INTO CANADA AND SIBERIA}

Figure 19 shows the distribution of foldbelts in Alaska and neighboring parts of Canada and Siberia. Foldbelts on this map are differentiated by gross ages of regional deformation, metamorphism, and intrusion. Using these criteria to delineate foldbelts, most of Alaska's structures were created during the 


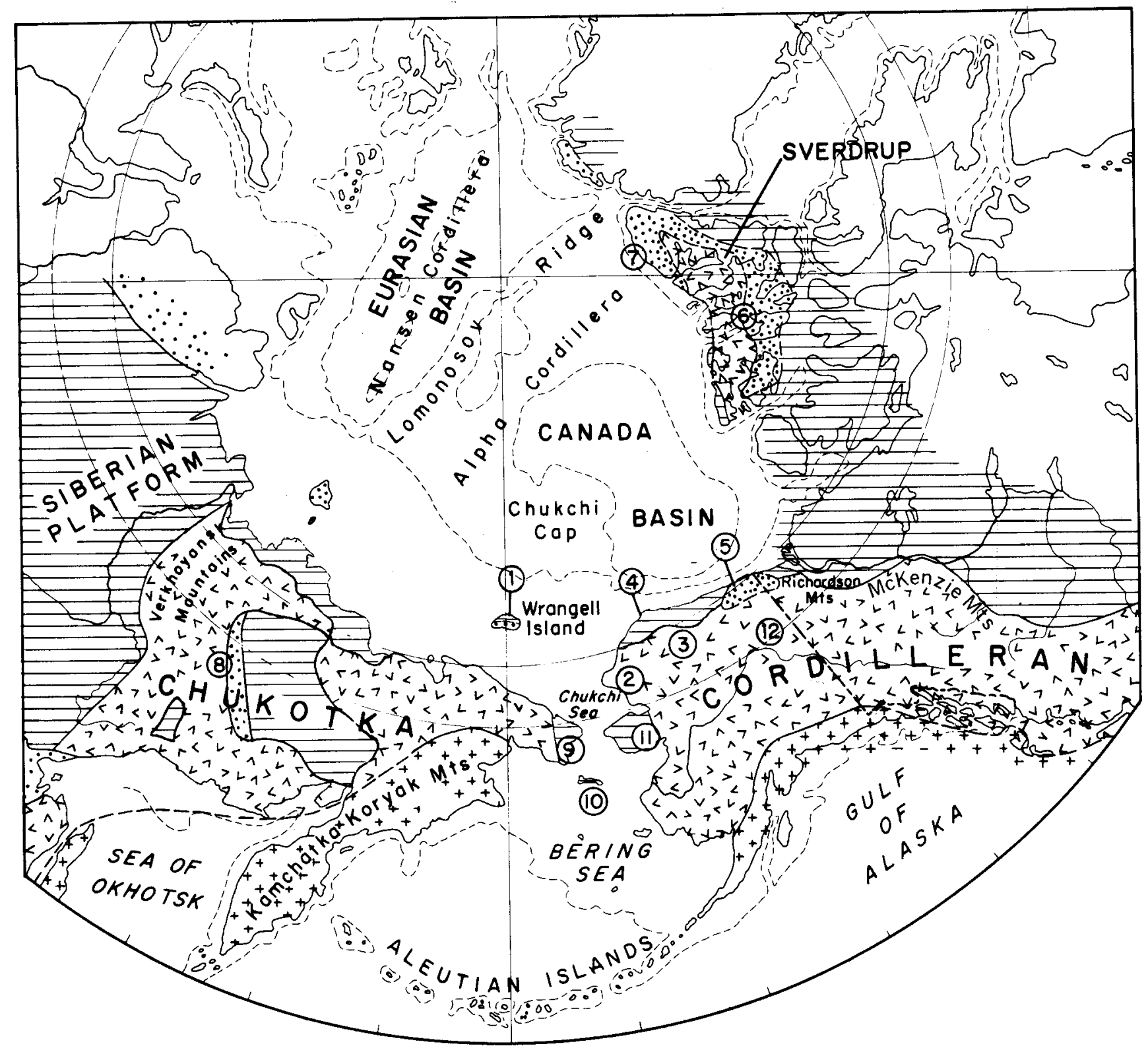

EXPLANATION

FOLDBELTS

$$
++++
$$

Circumpacific belt Mainly of Cenozoic age

$$
x^{2} \times 1,2
$$

Chukotka, Cordilleran, Sverdrup, and Verkhoyansk belts Mainly of Mesozoic age

$$
\because \because \because
$$

Canada Basin and Cherskiy

Circumartic belts

Mainly of Paleozoic age
PLATFORMS

Paleozoic and younger deposits and within continental interior including Precambrian basement

(1)

Location of columnar sections shown in figure 22

Figure 19.-Major foldbelts around the northern Pacific and the Canada Basin part of the Arctic Ocean. 
Mesozoic as parts of the Cordilleran foldbelt that lies along the western continental margin of North America (King, 1969).

The earliest deformational features within the Cordilleran foldbelt are the high-grade schist and gneiss terranes across the center of Alaska that form the basement rock of the Seward Peninsula and the Yukon-Tanana Upland. Historically, these terranes have been considered to be of Precambrian age. Numerous Mesozoic ages obtained by isotope dating of these schists and associated plutonic rocks, especially the Birch Creek Schist of east-central Alaska (Wasserburg and others, 1963), cast doubt on the Precambrian age of these structures. On the other hand, new isotopic dates on the metamorphic complexes in the Seward Peninsula (C. L. Sainsbury, oral commun., 1970) and the Fairbanks area (Forbes and others, 1968) indicate Precambrian, or at least earliest Paleozoic, ages of deformation. Along the Pacific and the Arctic Ocean margins of the Cordilleran foldbelt, there are, in a number of places, thick wedges of coarse clastic rocks associated with plutonic activity, indicating orogenies within the Paleozoic geosynclines (fig. 13). The climactic orogenies of the Cordilleran foldbelt, however, took place during the Mesozoic, and in many places, Cenozoic defo nation continued and is responsible for much of the present mountainous topography within the original foldbelts. High-grade metamorphism in southeastern Alaska involving lower Paleozoic rocks (Brew and others, 1966) and lower grade metamorphism of pre-Upper Devonian rocks in the northern Brooks Range (Reed, 1968) are other examples of these forerunners of the main Cordilleran orogeny. Thus, the Cordilleran foldbelt arose from deformation and in part from metamorphism and plutonism of several geosynclines, some of which took form in late Precambrian and early Paleozoic time, and others, as late as Mesozoic time (King, 1969).

The Cordilleran foldbelt north of the 49th parallel has a nearly constant width until it widens inland to form the Mackenzie Mountains in Northwest Territories. There, it is sharply confined along its northeast margin, trends north along the Richardson Mountains of Yukon Territory, and turns westward across Alaska, widening out to the Bering and Chukchi Seas (fig. 19). Easternmost Siberia, separated from Alaska by these broad continental shelves, is part of the Chukotka foldbelt of Mesozoic age (Yanshin, 1966). South of the Chukotka foldbelt is the circumpacific foldbelt, mainly of Cenozoic age. It includes the islands surrounding the Sea of
Okhotsk, Kamchatka, Koryak Mountains, and the Gulf of Alaska.

Another, though less obvious, foldbelt discontinuously rims the southern margin of the Canada Basin part of the Arctic Ocean (fig. 19). This is the much older circumarctic foldbelt of middle Paleozoic age that is known in the Canadian Arctic Islands (Thorsteinsson and Tozer, 1960), in the British Mountains of northern Yukon Territory, and in the northeastern Brooks Range (Churkin, $1969,1970)$. Farther west, this foldbelt is covered by the coastal plain deposits of northern Alaska. Boreholes along the Arctic coast of Alaska, in places at rather shallow depths, have penetrated steeply dipping slate, argillite, and graywacke of pre-Late Devonian age that probably belong to this same foldbelt. These rocks form the basement in the Prudhoe Bay oil field (Rickwood, 1970) and the basement of the Barrow arch, a broad structure of Mesozoic age that parallels the Arctic coast of Alaska (Payne and others, 1951).

One of the most prominent structural features within the Cordilleran foldbelt is the belt of folding and thrusting that starts along the east side of the Canadian Rocky Mountains and continues north into Yukon Territory where it turns west to make the Brooks Range in northern Alaska (fig. 20). Most of the rocks within this broad belt are Paleozoic carbonate rocks and shales, but rocks as old as late Precambrian or as young as Tertiary are also involved. This remarkably continuous belt has several arcuate bends (Gabrielse, 1967; King, 1969). At the north end of the Rocky Mountains the relatively narrow (less than 100 miles wide) and fairly straight foldbelt gives way to the Mackenzie Mountains (fig. 20), a broad series of arcuate ranges offset eastward into the Yukon shelf. From the Mackenzie Mountains, the foldbelt turns gently west into the Wernecke-Ogilvie Mountains. At the west end of the Ogilvie Mountains near the Alaska-Yukon Territory boundary, the foldbelt makes a sharp right-angle bend to form the north-south-trending Nahoni Mountains. Farther north the Nahoni Mountains give way to the northeast-trending | Dave Lord Ridge fold structures. North of the Porcupine River the foldbelt turns northwestward across the British Mountains in the northwest corner of Yukon Territory and crosses into Alaska to form the Brooks Range. The trend of the Brooks Range segment of the foldbelt is westerly for nearly 600 miles, and in the Baird Mountains at the west end of the Brooks Range, it bends south towards the Seward Peninsula, its northern margin making a sharp bend at Cape Lisburne where the 


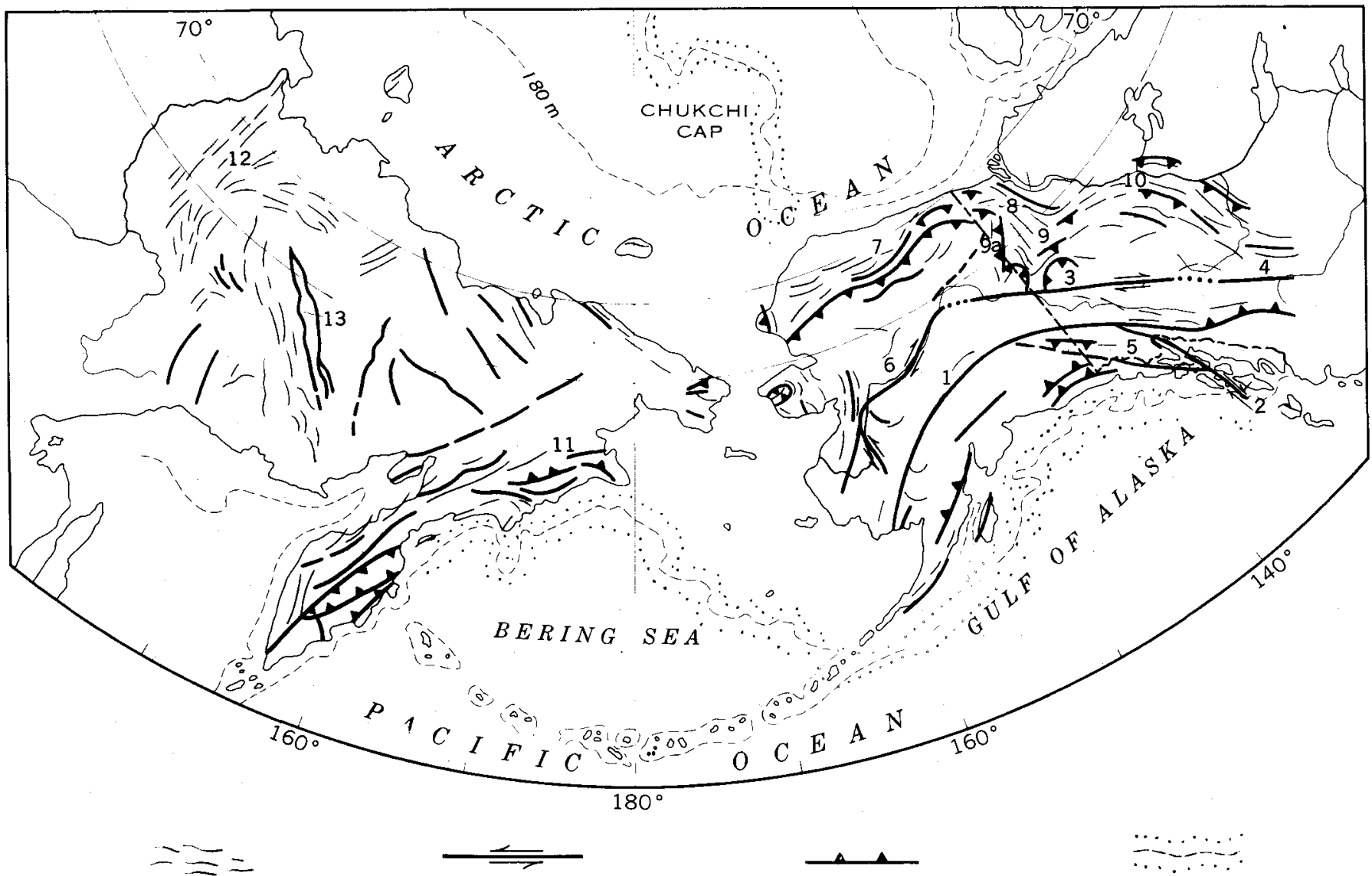

Generalized trend of folds Transcurrent fault. Arrows show inferred movement

Thrust fault. Barbs on upthrown side
Arcuate trends in continental margins

Figure 20.-Major structural features of the northern circumpacific and adjacent parts of the Arctic (after King, 1969; Yanshin, 1966). See list of features below.

\section{STRUCTURAL FEATURES}

1. Denali-Farewell-Holitna fault system.

2. Chatham Strait fault.

3. Tintina trench.

4. Rocky Mountain trench.

5. Chugach-St. Elias-Fairweather fault system.

6. Kaltag fault.

7. Brooks Range, British Mountains thrust and foldbelt.

8. Richardson Mountains foldbelt.

9. Nahoni-Ogilvie-Wernecke Mountains foldbelt.

9a. Dave Lord Ridge.

10. Mackenzie Mountains thrust and foldbelt.

11. Koryak thrust and foldbelt.

12. Verhoyansk foldbelt.

13. Cherskiy Mountain system thrust and foldbelt.

folds and faults trend northward under the Chukchi Sea (cf. Tailleur and Brosgé, 1970).

The deep recess in the foldbelt in northwestern Yukon Territory, where the structures from the Mackenzie Mountains and from the Brooks Range curve inward to form a sharp right angle, may be related to the structures of the Richardson Mountains located within the recess. The Richardson
Mountains themselves are apparently a blocklike uplift of thick e $e^{t}$ ly Paleozoic and Mesozoic basinal deposits surrounded by the much thinner rocks of the Paleozoic Yukon shelf (Jeletzky, 1962). At the time of major folding in the region, the thick body of Paleozoic and Mesozoic sedimentary rocks in the Richardson basin possibly acted as a buffer that diverted the fold and fault trends in the thinner sections of the Yukon shelf around its western and southern edge. Large-scale right-lateral movement along the Porcupine lineament (Tailleur and Brosgé, 1970), a probable fault zone (Brosgé and Reiser, 1969) that may be an extension of the Kaltag fault (Patton and Hoare, 1968), may also be responsible for the right-angle bend in the foldbelt near the Alaska-Yukon Territory boundary.

South of the Brooks Range, folds and thrust faults generally do not have the consistency of trend that they have in the Brooks Range and along the North Slope. The difficulty in distinguishing structural trends in southern Alaska is not that the 
rocks have escaped deformation but that multiple periods of deformation have created complex trends. The scarcity of good marker horizons in the thick eugeosynclinal sequences and multiple batholithic intrusions further complicate structural analyses.

Thrust faults involving Precambrian and Lower Paleozoic rocks have been recognized over a large part of the Seward Peninsula (Sainsbury, 1969b). In the western Seward Peninsula, unmetamorphosed carbonate rocks of Ordovician and Silurian age are imbricately thrust faulted and are in thrust-fault contact with slates and slightly metamorphosed carbonate rocks of probable pre-Ordovician age (Sainsbury, 1969a, 1969b). Farther west, across the Bering Strait from the Seward Peninsula, exposures along the sea cliffs of Chukotsk Peninsula reveal complicated imbrication of Ordovician and Silurian limestone with Devonian shales and other argillaceous, weakly metamorphosed rocks (S. G. Byalobzhevski, oral commun., 1967; Gnibidenko, 1969). The proximity of these similar stratigraphic and structural features suggests their correlation across the Bering Strait.

As the stratigraphy of other structurally complicated areas of Paleozoic rock in Alaska is studied, more examples of important thrust faulting will become known. Preliminary results of regional mapping in the Terra Cotta Mountains area of the Alaska Range (B. L. Reed, oral commun., 1969) and in the Annette Island area of southeastern Alaska (Berg, 1970) indicate that thrust faults involving Paleozoic rocks are important in these areas.

A record of structural juxtaposition of widely different rock types has been reported from the White Mountains at the west end of the YukonTanana Upland (Church and Durfee, 1961). Here, the Tolovana Limestone, consisting of a long and narrow outcrop belt of pure limestone and dolomite of Silurian and Devonian age, is in contact with the Fossil Creek Volcanics of Ordovician age, a unit characterized by siliceous sedimentary rocks and pillow basalt. According to Church and Durfee (1961), the limestone is everywhere thrust faulted over the volcanic rocks, however, the massive limestone was found by myself, in company with $R$. Chapman and F. Weber in 1968, to be accordant and, where best exposed, gradational over an interval of several feet into calcareous tuff. This interpretation of a stratigraphic contact agrees with the original interpretation of Mertie (1937b). This belt in the central part of Alaska, where carbonate rock sections are in close proximity and are partly interlayered with volcanic rocks and with fine-grained siliceous rock facies, marks a zone transitional in facies with mainly limestones to the north and volcanic-siliceous sequences to the south. The structure within this belt and its relation to the carbonate facies on the one hand and metamorphic rocks on the other is, however, very complex, and large-scale faulting may be partly responsible for some of the abrupt changes in rock types.

The amount of lateral displacement on the various thrust faults in Alaska is poorly known and, except for the instances discussed below, is not recognized as displacing major stratigraphic belts.

Several periods of south-to-north overthrusting during the Cretaceous and Tertiary affected the area that is now the Brooks Range (Lathram, 1965; Porter, 1966 ; Tailleur and others, 1967). Because of this multiple thrusting of unknown displacement, it is difficult to reconstruct the original facies within the Paleozoic rocks of northern Alaska. In the western Brooks Range large-scale overthrusts are thought to have a cumulative northward displacement probably in excess of 150 miles (Tailleur and Snelson, 1968). Thus far, it has not been possible to measure accurately amounts of total displacement because of the imbricate nature of the faulting. On a single fault in the Chandalar area of the central Brooks Range, 5 miles of horizontal displacement has been measured (W. P. Brosgé, oral commun., 1968). Because scores of subparallel faults have been mapped here, their aggregate displacement may be very substantial. Preliminary estimates of Paleozoic stratigraphic relations south to north across various parts of the Brooks Range have been made using palinspastic reconstruction across the multiple thrust sheets (Lathram, 1965; Tailleur and others, 1967).

LONGITUDINAL FAULTS AND TOPOGRAPHIC TRENCHES

In Alaska, as in more southern parts of the Cordilleran belt, there are many long fault zones that are frequently expressed topographically as trenches or valleys (fig. 20). Some of the more conspicuous faults and the way in which they affect Paleozoic rocks are discussed below.

The Tintina fault zone in east-central Alaska is marked by a narrow valley that parallels the Yukon River on its south side (Brabb and Churkin, 1965, 1970) and extends from Alaska southeastward across Yukon Territory to the Liard plain which separates the Tintina fault zone from the Rocky Mountain Trench (Roddick, 1967). The Tintina fault zone effectively separates the unmetamorphosed Precambrian-through-Mesozoic stratigraphic 
succession on its north side from the Birch Creek Schist-strongly metamorphosed, mainly siliceous sedimentary rocks and volcanics of probable Paleozoic and possible Precambrian age-on its south side. Granitic and ultramafic intrusions of Mesozoic age (except for the so-called Circle Volcanics) cut the metamorphic rocks south of the fault but do not extend north of the Tintina fault, thus further contrasting the widely different geologic terranes on both sides of the fault. Thick sections of nonmarine, poorly consolidated sandstone, mudstone, conglomerate, and minor coal of Late Cretaceous and Tertiary age are developed along the fault zone. Steep dips and faults cutting even the youngest Tertiary sedimentary rocks along the trenchlike valley indicate latest Tertiary and (or) Quaternary deformation. Large-scale lateral dislocation has been postulated along the fault. By matching an upper Precambrian quartzite-shale ("grit") unit north of the fault in Yukon Territory with a similar belt in the YukonTanana Upland of east-central Alaska, a rightlateral offset of about 260 miles has been suggested (Roddick, 1967).

The trace of the Tintina fault in the vicinity of Circle, Alaska, is not defined. It may continue straight into the Yukon Flats northwest of Circle or bend sharply westward parallel to the trend of the White and Crazy Mountains and possibly connect with the Kaltag fault that continues southwestward into Norton Sound (Patton and Hoare, 1968). Still another possible northern termination of the Tintina may be along a set of subparallel splays in the Livengood area where a number of throughgoing faults (F. R. Weber, oral commun., 1969) may reflect the taking-up of the substantial displacement postulated for the fault farther to the southeast.

The Kaltag fault controls the course of a long reach of the Yukon River and, like the Tintina, in places is marked by rift valleys and fault scarps that cut Tertiary and Quaternary deposits developed along it (Patton and Hoare, 1969). Seismic reflection profiles on the shallow Bering Shelf reveal a sediment-filled trough that is interpreted to be the seaward continuation of the Kaltag fault (Scholl and others, 1970). The major geologic trends in the area-the Yukon-Koyukuk basin of Cretaceous age and a belt of metamorphic rocks of Paleozoic and early Mesozoic age-have been displaced between 40-80 miles right laterally across the fault, and modern stream courses are offiset as much as 1.5 miles (Patton and Hoare, 1968). If the Kaltag and Titina faults are differently trending segments of the same fault system, they have an arcuate trend nearly parallel to the Denali fault system farther south.

The Denali fault of southern Alaska is the longest throughgoing fault system in southern Alaska (St. Amand, 1957). The Denali fault is made up of several fairly straight segments that apparently interconnect at slight angles to give it an arcuate trend (Grantz, 1966). There are many subsidiary faults and strands, especially in its central part in the Alaska Range. According to St. Amand (1957), the Denali fault system may have had 150 miles of rightlateral strike-slip displacement since the start of the Pliocene. Because numerous geologic and topographic anomalies would result from this amount of displacement, Grantz (1966) suggested somewhat smaller and mainly older, Mesozoic, movement with the amount of displacement across the fault varying from segment to segment. The Chatham Strait fault -a possible continuation of the Denali into southeastern Alaska-separates regions of strongly contrasting geology (Twenhofel and Sainsbury, 1958; Lathram, 1964). About 120 miles of right-lateral separation is suggested by displacement of Paleozoic and Tertiary rocks on either side of the fault (Lathram, 1964). In addition to this lateral displacement, several kilometers of vertical movement is assigned to the same fault (Loney and others, 1967).

South of the Denali fault is another group of transcurrent faults that are more widely separated and seem to have different directions of displacement (fig. 20). In the future, more detailed correlations of Paleozoic stratigraphy will increasingly depend on the recognition of displacements on these, and other, major faults.

CORRELATION OF THE PALEOZOIC ROCKS AROUND THE EDGES OF THE ARCTIC AND NORTHERN PACIFIC BASINS AND SEAFLOOR SPREADING IN THE ARCTIC

The old idea of continental drift of North America from Eurasia has been revived by new oceanographic data and incorporated into the theory of seafloor spreading and plate tectonics. In the attempts to reconstruct how the drift has occurred, North America is considered as a block separate from the Eurasian block, and differential movement has been postulated between the two blocks (Blackett and others, 1965). The mid-Atlantic Ridge and its northern extension across the Arctic Ocean are considered by many as the eastern boundary of North America (fig. 21). In the Pacific realm, the position of the boundary separating North America from Eurasia 


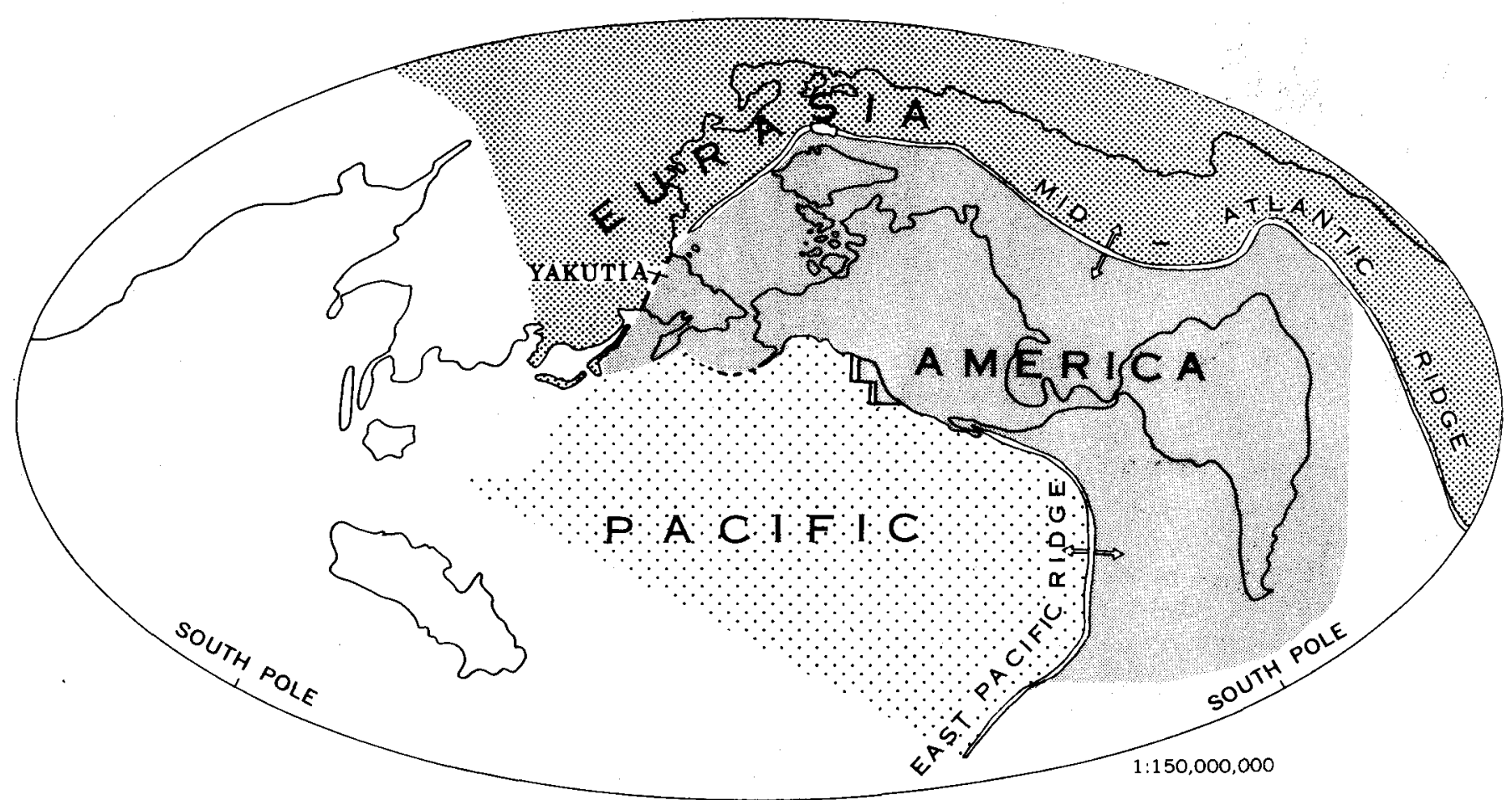

FIGURE 21.-Boundaries of the major crustal plates in the Northern Hemisphere.

is less certain, but it has been drawn between Chukotka and Alaska (Le Pichon, 1968). If drift has occurred in the northern Pacific, there should be some geologic evidence of movement between these two continent blocks in the Bering Sea region.

The Cenozoic geology of the Bering Sea area, recently summarized by Hopkins (1967), indicates that there is a complex record of sea-level changes and intermittent land connections across the Bering Straits and that the North American and Eurasian continents appear to have been connected at least since the early Tertiary.

No significant breaks in the Mesozoic and Cenozoic geologic trends have been reported to substantiate continental drift between North America and Eurasia where they come together in the northern Pacific. If drift occurred, however, it is the preMesozoic rocks and structures that should show the greatest displacement. A direct comparison of the pre-Mesozoic geology of Alaska with that of Northeast U.S.S.R. will now be made in search of evidence of differential movement between the two continents.

Wrangell Island, connected by a bathymetric
(Creager and McManus, 1965) and a gravity anomaly trend (Ostenso, 1968b) across the Chukchi Sea to Lisburne Peninsula, seems to represent a westward extension of the pre-Cretaceous rocks of the Brooks Range (Holmes and others, 1968; Grantz and others, 1970). The oldest fossiliferous rocks, of Mississippian age, occur in the central part of Wrangell Island as part of a thick sequence of marine sedimentary rocks (fig. 22). Nonmarine beds of chert-quartz conglomerate form the lower part of the sequence. The presence in the western Brooks Range of similar conglomerates of Late Devonian age in a stratigraphic section comparable to that in Wrangell Island has been noted (Bogdanov and Tilman, 1964). These conglomerates are part of a series of clastic wedge deposits that continued around the edge of the Canada Basin from the Soviet Arctic (Chukotka and Wrangell Island), across northern Alaska (Churkin, 1969), and then across the Canadian Arctic Islands at least as far as Ellesmere Island (Trettin, 1967).

Intrusive rocks on Wrangell Island include dikes and small plutonic bodies, mainly of granitic com- 

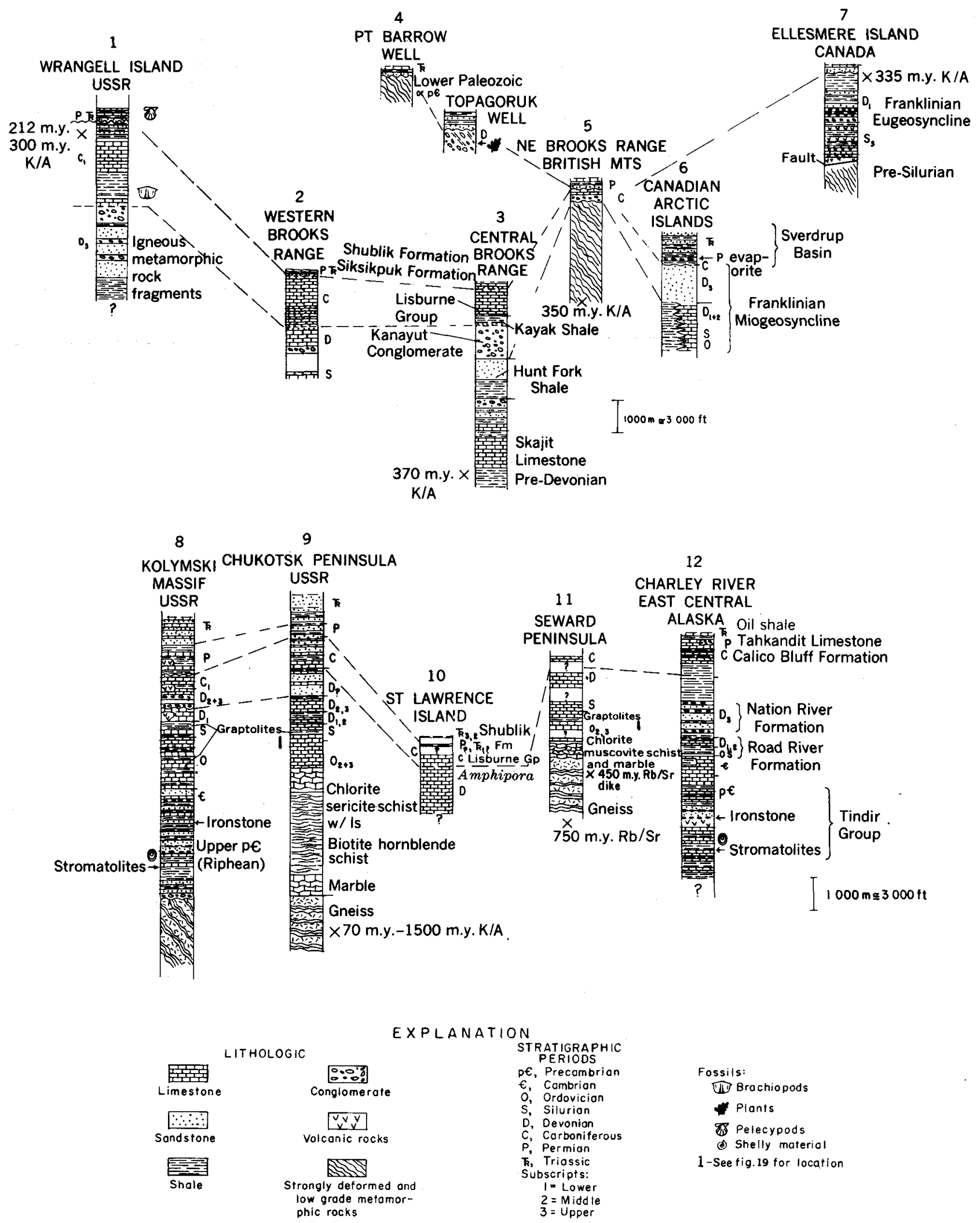

FIGURE 22.-Correlation diagrams of the Paleozoic and Precambrian stratigraphy around the Canada Basin and central parts of Alaska and Northeast U.S.S.R. 
position. They cut the Paleozoic section, but nowhere are they reported to affect the Triassic strata. The age of these rocks, supported by potassium-argon isotope dating, is thought to be late Paleozoic (fig. 22). Absolute age determinations of granitic rocks farther east around the margin of the Canada Basin indicate that similar intrusions were probably related to a widespread middle Paleozoic orogeny that produced wedges of Upper Devonian conglomerate and sandstone (Tailleur and others, 1967; Trettin, 1967; Churkin, 1969).

On Wrangell Island the Mississippian rocks, like the underlying Upper Devonian rocks, are very similar to, but thicker than, those in the Brooks Range. Permian and Triassic rocks, mainly clastics, unconformably overlie the Mississippian, and again there is a similarity to the stratigraphy of the Brooks Range (fig. 22). In the Canadian Arctic Islands, an even thicker sequence of Carboniferous and younger rocks lies unconformably on the older Paleozoic rocks of the Franklinian geosyncline and forms the Sverdrup Basin (Thorsteinsson and Tozer, $1960)$.

The rocks at the western tip of the Seward Peninsula and at the eastern tip of Chukotsk Peninsula where the two continental landmasses come closest together should show most clearly evidence of differential movement between the continents. For comparison, the basic elements of the geology of the Cape Dezhneva area, the easternmost tip of Chukotsk Peninsula and the land point nearest to the Seward Peninsula, are shown in figure 23.

In the Cape Dezhneva area, there is a gneiss and amphibolite central dome that is surrounded progressively outward by marble and schist that is, in turn, interlayered with partially recrystallized limestones. Shelly fossils in these limestones are of Ordovician, Silurian, Devonian, and Carboniferous age (Gnibidenko, 1969, p. 11-13). Granite and a syenite intrusion coupled with imbricate thrust faulting (S. G. Byalobzhevski, oral commun., 1967) complicate the structure. About 15,000 feet of schist and gneiss is reported by Gnibidenko to underlie conformably the limestone with Late Ordovician fossils. Directly across the narrow Bering Strait in the Seward Peninsula, the west-trending Kigluaik Mountains expose, in their core, gneiss and biotite schists that have a well-defined domal structure (Collier and others, 1908, p. 67) (fig. 22). Overlying these highgrade metamorphic rocks are lower grade schists characterized by chlorite and muscovite. Marble is interlayered with the schist, especially in its upper part. Thin-bedded argillaceous limestone seems to overlie the schist and, in turn, is overlain to the north by a complexly thrust faulted sequence of massive limestone containing Ordovician and Silurian fossils (Sainsbury, 1969a).

C. L. Sainsbury (written commun., 1970) has obtained a 750-m.y. date on gneiss in the Kigluaik Mountains using the rubidium-strontium whole-rock method. According to Sainsbury, a dike cutting this same gneiss gives a 450-m.y. date. On the other hand, dating of other metamorphic rocks and associated intrusives in the general area using the potassium-argon method indicates a Cretaceous metamorphic-plutonic event (Sainsbury, 1969a). In the nearby Chukotsk Peninsula most of the dates on intrusive and metamorphic rocks are again Mesozoic, but a number of much older dates, ranging from 1,500 to 700 m.y., have been obtained on rocks in the same vicinity as those giving Mesozoic dates (Gnibidenko, 1969). Thus, there is a close correlation of stratigraphy and metamorphism in the oldest rocks across the Bering Strait (Churkin, 1970). The occurrence of comparable tin deposits in both the Seward and Chukotsk Peninsulas (Sainsbury, 1969a) and the occurrence of rare alkali-rich plutonic rocks in both regions (Miller, 1972) provide other examples of the close similarity in the geology across the Strait.

A comparison of upper Paleozoic and lower Mesozoic stratigraphy between eastern Chukotka and the Seward Peninsula is not possible because only isolated fragments of these rocks are available for comparison in Seward Peninsula. On St. Lawrence Island, however, in the middle of the Bering Shelf, a rather complete Devonian-through-Triassic section has been reported by Patton and Dutro (1969). The section here closely resembles that of the western Brooks Range on the east and the Chukotsk Peninsula on the west (fig. 22).

On both sides of the Bering Straits, at about the same latitude but much farther inland, are rather similar and much more complete sequences ranging in age from Precambrian to Triassic (fig. 22). In Alaska, this is the section exposed in the YukonPorcupine Rivers area (Churkin and Brabb, 1967); in Siberia, it is the section in the Kolymski massif (Bogdanov, 1963). These two relatively stable areas are characterized mostly by carbonate rock sections nearly surrounded by thicker, more terrigenous deposits.

In Northeast U.S.S.R., as in Alaska, the depth to the Mohorovicic discontinuity, except for some deep roots below high mountains, generally rises closer to the surface as the Arctic and Pacific Ocean basins 


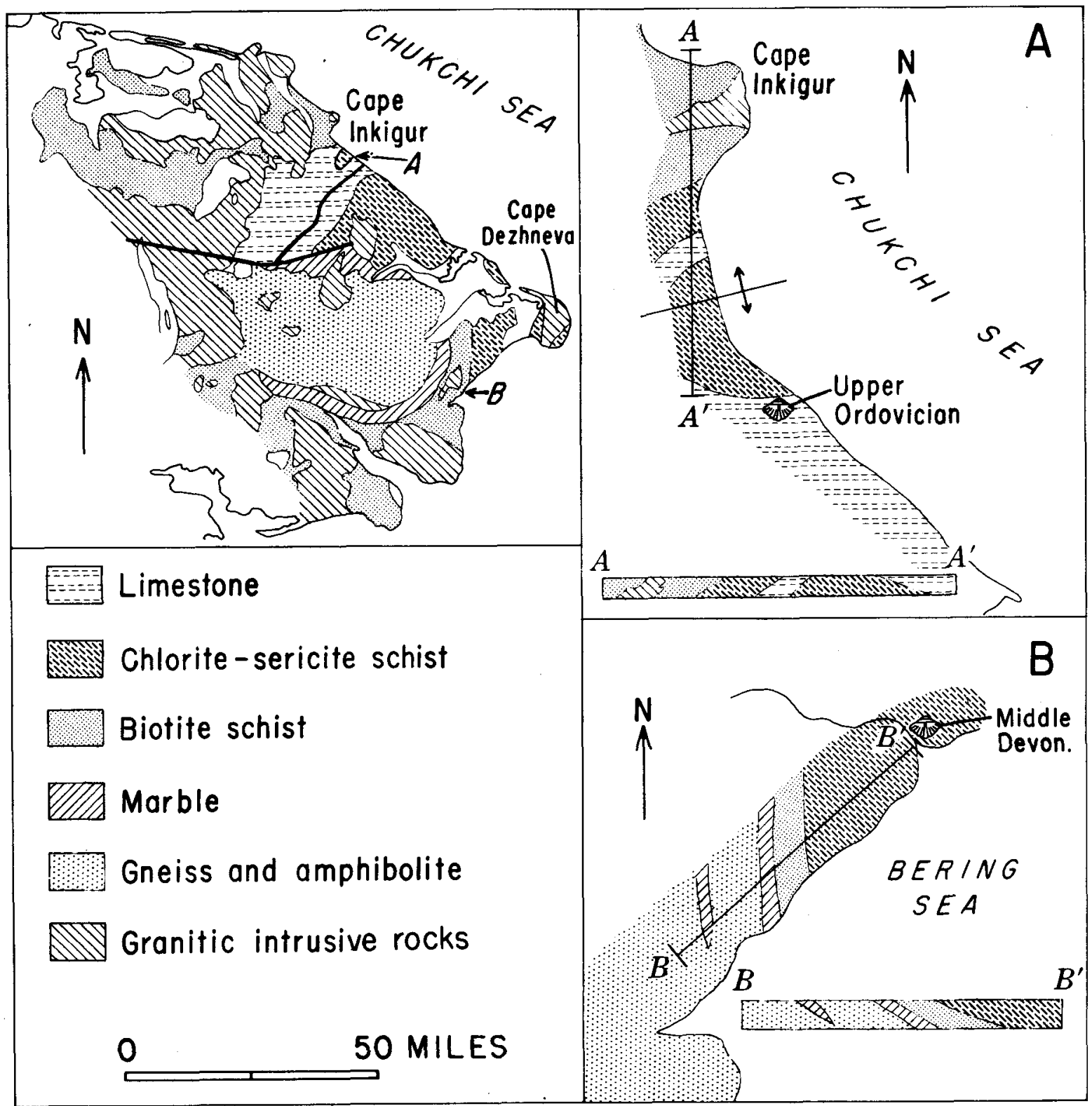

FIGURE 23.-Geologic map of the Cape Dezhneva area, easternmost tip of Chukotsk Peninsula, U.S.S.R., showing fossil localities and structure sections.

are approached (Nikolaevskiy, 1964; Woollard and others, 1960). The preliminary inference that a trend of high crustal thickness across the center of Alaska connects with a comparable trend across the center of Chukotka suggests another correlation of the geology across the Bering Straits.

One of the most compelling lines of evidence against a major discontinuity in the geology of the Bering Sea region is a correlation of Paleozoic sections (Churkin, 1970) that leads to the paleotectonic reconstruction shown in figure 1. A Paleozoic geosyncline rims the northern Pacific, and another geosyncline rims the southern margin of the Arctic Basin. Separating the two geosynclines is a narrow stable area that received mainly carbonate sediments extending perhaps discontinuously from the North American craton to the Kolymski massif of Siberia.

These different lines of evidence considered together indicate a close similarity between the geologic histories of the opposing edges of the Bering and Chukchi Seas and a continuity of geologic features between Alaska and eastern Siberia that imply these landmasses have been connected since the 
Paleozoic and probably since the Precambrian (Churkin, 1970).

Alternate locations of the western boundary of the North American plate have been suggested within the Asian continent. In order to evaluate these possible boundaries, it is necessary to first consider some of the characteristics of the midAtlantic Ridge and the transarctic spreading center that apparently runs into the continental margin of Asia.

The seismically and volcanically active mid-Atlantic ridge extends north from Iceland between Greenland and Spitsbergen (Vogt and others, 1970) and with apparent decreased seismicity (Sykes, 1965) continues across the Eurasia Basin as the Gakkel Ridge (Nansen Cordillera) that lies midway between the Lomonosov Ridge and the continental margin of Eurasia (Heezen and Tharp, 1965; Demenitskaya and Karasik, 1969) (fig. 2). Magnetic profiles associated with the Gakkel Ridge show axial symmetry and correlate with profiles in the North Atlantic and in the Norwegian Sea (Vogt and others, 1970; Wold and Ostenso, 1971). A quantitative attempt to verify these correlations implies that the Gakkel Ridge spreading history started about 40 m.y. B.P. (before present) (Wold and Ostenso, 1972), but spreading rates of about $1 \mathrm{~cm} / \mathrm{yr}$ (Vogt and others, 1970) calculated for the ridge are admittedly speculative. Estimates of the rate of seafloor spreading in the North Atlantic are also thought to have been about $1 \mathrm{~cm} / \mathrm{yr}$ (Vine, 1966 ; Vogt and others, 1970), and considerably slower than in the central and southern Atlantic. Reconstructions of the history of the Atlantic opening (Dietz and Holden, 1970) suggest that its opening proceeded northward and reached the Grand Banks in about Triassic time. Further extension of the Atiantic rift had started to block out the eastern margin of Greenland by Cretaceous time, and in the Cenozoic the rift extended into the Arctic (Johnson and Heezen, 1968; Vogt and others, 1970).

These data are consistent with the idea that the Eurasia Basin (with the Lomonosov Ridge as one margin) is a wedge-shaped depression having its apex in the Sea of Laptev and its widest part near the Atlantic (Wilson, 1963; Churkin, 1970). The pole of rotation or pivot of North America with respect to Eurasia to produce the opening of the northern Atlantic and Eurasia Basins has been determined to be $78^{\circ} \mathrm{N}$., $102^{\circ} \mathrm{E}$. The point was determined by using azimuths of fracture zones across the northern part of the mid-Atlantic ridge (Morgan, 1968; Le Pichon, 1968). This pole lies in the vicinity of the Taimyr Peninsula near the apex of the Eurasia Basin. Another estimate of the pole of rotation, using the best fit of Greenland to Europe, averages out any changes in direction of spreading and gives a position $73^{\circ}$ N., 96.5 E. (Bullard and others, 1965). It appears significant that the two poles of rotation calculated independently are reasonably near the apex of the Eurasia Basin opening.

An analysis of geophysical data suggests that the tensional tectonic conditions of the Gakkel spreading center do not stop at the head of the Eurasia Basin but continue into the continental framework of eastern Siberia (Demenitskaya and Karasik, 1969). The Sadko trough, an unusually large submarine canyon at the head of the Eurasia Basin, is alined with the Gakkel Ridge, is the locus of earthquakes, and is reported to be a rift feature (Demenitskaya and Karasik, 1969) (fig. 24). The shallow Laptev Sea, at the head of the Eurasia Basin, contains a thick blanket of sediments deposited by the Lena and other major rivers. These sediments have obscured the landward extension of the Sadko trough or any other structures alined with the Gakkel Ridge. The line of earthquake epicenters along the Gakkel Ridge and Sadko trough, however, continues across the Sea of Laptev where it splits into a southerly trend that follows the Verkhoyansk Mountains and a more southeasterly trend that follows the Cherskiy system of mountain ranges and depressions (Rezanov, 1964). According to Rezanov, very active Quaternary tectonic movements in the Cherskiy Mountain system have produced large uplifts and depressions in this, the most active earthquake belt in Northeast U.S.S.R. Faulting and volcanism here has been recognized as a landward extension of the sea-floor-spreading tectonics of the Gakkel submarine ridge (Demenitskaya and Karasik, 1969). The available data from the Laptev Sea area, in my opinion, suggest that the tectonic conditions here may be similar to those in the Gulf of California where faulting extends inland from the East Pacific Rise (Larson and others, 1968).

The western boundary of the North American plate has been assumed to lie in the Verkhoyansk Mountains of Yakutia (Wilson, 1963; fig. 24). According to Wilson, the Verkhoyansk Mountains, south and on trend with the apex of the Eurasia Basin of the Arctic Ocean, were deformed in Late Jurassic to early Tertiary and Pliocene to Holocene, the major periods of spreading in the Atlantic and Arctic. Based on earthquake epicenters that cross 


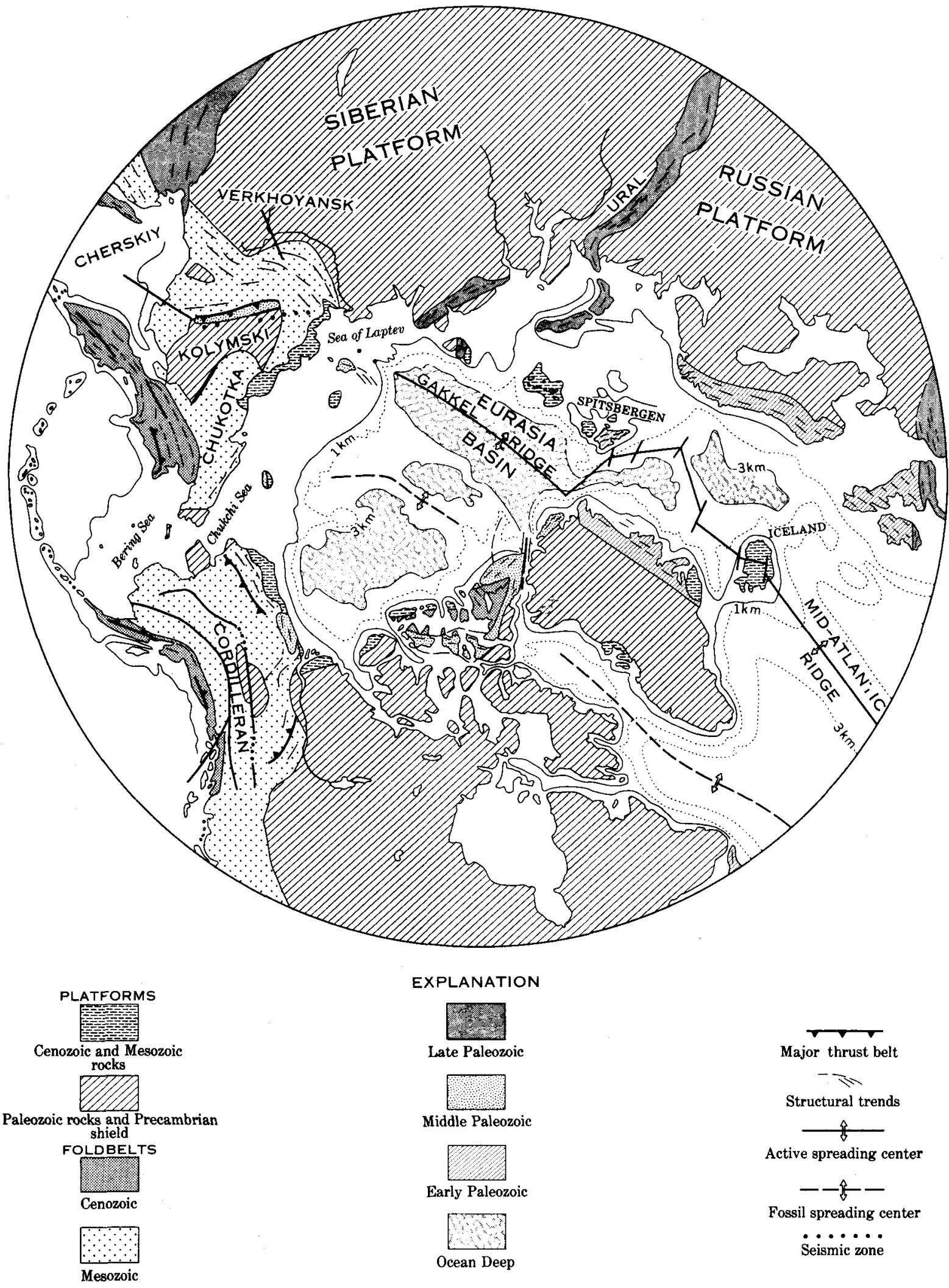

Figure 24.-Major tectonic features of the Arctic. 
Siberia on trend with the Gakkel spreading center (Sykes, 1965), a plate boundary separating America from Eurasia was also drawn along the Verhoyansk Mountains (Heezen and Tharp, 1965; Morgan, 1968). These data were summarized (Churkin, 1970) and interpreted to suggest a hinge zone in the Laptev Sea (as proposed earlier by Wilson) with tension north of the zone and compression south of the zone.

Compared to the tectonic activity in the Cherskiy system of mountain ranges and depressions, there is little evidence for an active plate boundary within the Verkhoyansk foldbelt. Except for some seismic activity and broad uplifts, the area lacks the throughgoing faults and igneous activity that mark major plate boundaries (Churkin, 1972b). Evidence for a fossil plate boundary within the Verkhoyansk foldbelt proper is also lacking. The rocks of the Verkhoyansk foldbelt are deformed into broad open folds and, in many places, are flat lying. Largescale displacements of geologic trends, overturned folds, thrust faults, melanges, great transcurrent faults, and associated high-pressure metamorphism and igneous activity that are recorded along plate boundaries elsewhere are not reported here (Yanshin, 1966). If there is a major break in the geology of the region, it would have to lie below the upper Paleozoic and Mesozoic rocks of the Verkhoyansk geosynclinal complex.

Numerous stratigraphic, structural, and petrological features in the Cherskiy Mountain system suggest that this mountain system, where it comes in contact with the Verkhoyansk foldbelt, marks a fossil plate boundary along which the Eurasian and North American continental plates were sutured. The compressional features of late Paleozoic and especially Mesozoic age along this boundary contrast strongly with the more recent, mainly tensional movements along the east side of this region that have been related to sea-floor spreading on the Gakkel Ridge and to modern plate motions in the Eurasia Basin part of the Arctic.

Major faults in the Cherskiy Mountain system separate three fundamentally different stratigraphic sequences of Cambrian through early Carboniferous age (Bogdanov, 1963). To the east, the Kolymski massif exposes a sequence $1,500-3,000 \mathrm{~m}$ (meters) thick of carbonate strata interlayered with sandstone and shale of latest Precambrian (Riphean) and Cambrian through Devonian age. This sequence rests unconformably on complexly deformed Proterozoic basement (fig. 22). West of this platform section, in the eastern ranges of the Cherskiy Moun- tain system, is a tightly folded, mainly carbonate rock section of Ordovician through early Carboniferous age that is much thicker, as much as 13,000 $m$. Farther west, along the western edge of the Cherskiy Mountains, a largely clastic section of Ordovician-through-Carboniferous strata that includes mafic volcanic rocks, is more than $8,000 \mathrm{~m}$ thick. These rocks are isoclinally folded and are cut by large thrust faults dipping east. The western edge of this major fault zone marks the boundary of the Paleozoic geosyncline in the Cherskiy Mountains with the early Mesozoic rocks, mainly Triassic and Jurassic, of the Verkhoyansk geosynclinal complex (Bogdanov, 1963). In places, Paleozoic rocks of the Cherskiy foldbelt are thrust west over the Mesozoic rocks of the Verkhoyansk foldbelt. This can be explained either as a product of westward overthrusting of the Paleozoic rocks or by eastward underthrusting of the Mesozoic rocks. High pressure minerals are developed along these faults in wide zones of breccia and mylonite (Dobretzov and others, 1966). Along this zone of regional faults is developed another large-scale feature-a belt $1,1000 \mathrm{~km}$ (kilometers) long of granitic batholiths mainly of Early Cretaceous age but including some of Late Jurassic age.

In general, the Cherskiy foldbelt that developed along the western margin of the Kolymski massif represents a long period of geosynclinal sedimentation that lasted through the early and middle Paleozoic, followed by thrust faulting and plutonic activity that closely parallels the history of the development of the major foldbelts rimming the North America craton (King, 1969). In fact, the stratigraphy of the Cherskiy foldbelt resembles in considerable detail that of the Cordilleran foldbelt (cf. fig. 22, cols. 8 and 12). The major distinction between the Cherskiy foldbelt and those of North America is that the Cherskiy foldbelt, like the Ural foldbelt, lies wholely within a continental landmass and separates the Siberian platform or craton on the west from the Kolymski massif on the east (fig. 24).

The eastern Verkhoyansk-western Cherskiy region marks the site of a major seaway that separated the Siberian platform from the Kolymski massif during the early Paleozoic (Churkin, 1972b). There is some evidence that points to a closing of this seaway in the middle Paleozoic. Coarse clastic sediments in the upper parts of the Devonian and in the lower Carboniferous sections of the Cherskiy foldbelt had western sources from a location now occupied by the Verkhoyansk foldbelt (Bogdanov, 
1963 , p. 155,162$)$. The presence of granitic detritus in these conglomerates, together with radiometric age dating of small granitic plutons in the western part of the area, has been related to a major period of uplift and folding during the Carboniferous that affected the Cherskiy geosyncline.

In the Permian, another cycle of sedimentation started which resulted in thick Triassic and Early Jurassic deposits laid down in the Verkhoyansk area. In the Late Jurassic and Early Cretaceous, this last period of geosynclinal sedimentation closed with a climactic orogeny that deformed the geosynclines into foldbelts and resulted in metamorphism and batholithic intrusion. Within Yakutia there is ample evidence of compression that requires considerable crustal shortening. The big question, it seems to me, is how much lateral transport has occurred in closing the Paleozoic and Mesozoic seaways that successively separated the Siberian platform and the Kolymski massif? Estimates of seafloor spreading in the northern Atlantic indicate a rate of spreading (about $1 \mathrm{~cm} / \mathrm{yr}$, Vine, 1966) and different amounts of Atlantic opening since the Triassic (Dietz and Holden, 1970). These estimates and reconstructions indicate that more than 1,000 $\mathrm{km}$ of total separation had already occurred on the Atlantic side of North America before the Early Cretaceous, the time of climactic orogeny in Yakutia. If this amount of separation had occurred on the Atlantic side of North America, there should be some dramatic expression of this drift bringing the Pacific sides of North America and Eurasia closer together, assuming they were once separated (Churkin, 1969, 1970). If global movements of this magnitude took place, then the closure of a major seaway in the Yakutia region between the leading edges of the approaching Eurasian and North American continental plates could have culminated with continental collision by Early Cretaceous time.

Sharp bends in the structures of southern Alaska and Chukotka have also been interpreted as products of drift of North America relatively toward Eurasia (Grantz, 1968). These curved structures include the long faults in southern Alaska (fig. 20) and those in the Koryak Mountains of Chukotka. Mesozoic and older tectonic elements (figs. 1, 17, 18) that are subparallel to these faults also reflect a bend in the stratigraphic belts of Alaska. Moreover, the curved continental margin of the Bering Sea, Gulf of Alaska, and possibly the northward prolongation of the Chukchi shelf margin around the Chukchi Cap could also be products of this movement (fig. 20).
A complication of this simplified analysis of compressional bending in the Alaska-Chukotka region as a consequence of tensional opening of the Atlantic is that the strongly curved southern continental margins of Alaska and Chukotka and some of the subparallel trends in the stratigraphic and structural belts farther inland may be the result of thrusting of the Pacific floor against the continental margins of Alaska and Chukotka-a hypothesis supported by studies of magnetic anomalies in the Gulf of Alaska (Pitman and Hayes, 1968), faults and folds along the Gulf of Alaska (Stoneley, 1967) and in the Koryak Mountains of Chukotka (Bogdanov in Peive, 1969), and land movements associated with the Alaska earthquake of 1964 (Plafker, 1969).

Finally, the geologic history around the margin of the Canada Basin, together with geophysical data from the basin itself, provides ways of answering questions concerning the age and origin of this part of the Arctic Ocean basin (Churkin, 1969, 1972b). From the stratigraphic data presented earlier, there is evidence that an early Paleozoic geosyncline rimmed the Canada Basin. Starting in the Late Devonian, uplifts in this geosyncline, accompanied by granitic intrusion, produced wedges of coarse clastic sediments that spread southward onto adjoining areas of Alaska, Canada, and Siberia. On the basis of the early development of geosynclines along the margins of the modern Canada Basin, followed by deformation, metamorphism, granite intrusion, and major uplift and clastic wedge sedimentation, a proto-Canada Basin with continental margin tectonics existed at least from Cambrian through Middle Devonian time. In the Late Devonian and Early Mississippian there was a closing of the proto-Canada Basin with deformation, metamorphism, plutonic activity, and major uplift that culminated in the accretion of the ancestral Brooks and Franklinian geosynclines to the Arctic margin of North America. During the Mississippian through the Triassic, successor basins with restricted marine sedimentation developed on the roots of the earlier geosynclines.

The modern Canada Basin seems to have opened in the Late Jurassic or Early Cretaceous when coarse clastic sediments were first shed from bordering parts of North America toward the basin. By Late Cretaceous time the Canada Basin had deepened sufficiently to accommodate the turbidites, submarine canyon and delta deposits that lead into the basin. 


\section{REFERENCES CITED}

Armstrong, A. K., 1970a, Mississippian dolomites from Lisburne Group, Killik River, Mount Bupto region, Brooks Range, Alaska: Am. Assoc. Petroleum Geologists Bull., v. 54, p. 251-264.

1970b, Mississippian rugose corals, Peratrovich Formation, West Coast, Prince of Wales Island, southeastern Alaska: U.S. Geol. Survey Prof. Paper 534, 44 p.

Armstrong, A. K., MacKevett, E. M., Jr., and Silberling, N. J., 1969, The Chitistone and Nizina Limestones of part of the southern Wrangell Mountains, Alaska-A preliminary report stressing carbonate petrography and depositional environments, in Geological Survey research, 1969: U.S. Geol. Survey Prof. Paper 650-D, p. D49-D62.

Armstrong, A. K., and Mamet, B. L., 1970, Biostratigraphy and dolomite porosity trends of the Lisburne Group, in Adkison, W. L., and Brosgé, M. M., eds., Proceedings of the geological seminar on the North Slope of Alaska: Los Angeles, Pacific Sec., Am. Assoc. Petroleum Geologists, p. N1-N15.

Armstrong, A. K., Mamet, B. L., and Dutro, J. T., Jr., 1970, Foraminiferal zonation and carbonate facies of Carboniferous (Mississippian and Pennsylvanian) Lisburne Group, central and eastern Brooks Range, Arctic Alaska: Am. Assoc. Petroieum Geologists Bull., v. 54, p. 687-698.

Baadsgaard, Halfdan, Folinsbee, R. E., and Lipson, J. I., 1961, Caledonian or Acadian granites of the northern Yukon Territory, in Raasch, G. O., ed., Geology of the Arctic, V. 1: Toronto, Ontario, Univ. Toronto Press, p. $458-465$.

Belyi, V. F., 1964, K voprosu o zhestkoi strukture vostochnoi Chukotki i Alyaske: Materyaly po geologii i poleznym iskopaemym Severo-Vostoka SSSR, Magadan, no. 17, p. $40-48$.

Berg, H. C., 1970, Paleozoic plutonism and contrasting metamorphic terranes, Annette Island, Alaska: Geol. Soc. America Abstracts with Programs, v. 2, p. 70 .

Blackett, P. M. S., Bullard, Edward, and Runcorn, S. K. (organizers), 1965, A symposium on continental drift: Royal Soc. [London] Philos. Trans., Ser. A, v. 258, no. $1088,323 \mathrm{p}$.

Bogdanov, N. A., 1963 Tektonicheskoe razvitie v Paleozoe Kolymskogo Massiva i vostochnoi Arktiki [Tectonic development of the Kolyma Massif and eastern Arctic in the Paleozoic]: Akac. Nauk SSSR, Geol. Inst., Trudy, v. 99,239 p.

Bogdanov, N. A., and Tilman, S. M., 1964, Obshchie cherty razvitiya Paleozoiskikh struktur ostrova Vrangelya i zapadnoi chasti Khrebta Bruksa (Alyaska) [Similarities in the development of the Paleozoic structures of Wrangell Island and the western part of the Brooks Range (Alaska), in Soveshchanie po Problem Tektoniki, Moscow, 1963, Skladchatye oblasti Evrazii, Materialy]: Moskva, Nauka, p. 219-230.

Bond, G. C., 1971, Early Permian sedimentation and paleogeography in east-central Alaska Range, and regional implications [abs.]: Internat. Symposium Arctic Geology, 2d, Pacific Sec., Am. Assoc. Petrol. Geologists, p. 8.
Bowsher, A. L., and Dutro, J. T., Jr., 1957, The Paleozoic section in the Shainin Lake area, central Brooks Range, Alaska: U.S. Geol. Survey Prof. Paper 303-A, 39 p.

Brabb, E. E., 1967, Stratigraphy of the Cambrian and Ordovician rocks of east-central Alaska: U.S. Geol. Survey Prof. Paper 559-A, p. A1-A30.

Brabb, E. E., 1969, Six new Paleozoic and Mesozoic formations in east-central Alaska: U.S. Geol. Survey Bull. 1274-I, p. 11-126.

Brabb, E. E., and Churkin, Michael, Jr., 1965, Preliminary geologic map of the Eagle D-1 quadrangle, east-central Alaska: U.S. Geol. Survey open-file map, scale 1:63,360.

1967, Stratigraphic evidence for the Late Devonian age of the Nation River Formation, east-central Alaska, in Geological Survey research, 1967: U.S. Geol. Survey Prof. Paper 575-D, p. D4-D15.

1969, Geologic map of the Charley River quadrangle, east-central Alaska: U.S. Geol. Survey Misc. Geol. Inv. Map. I-573, scale 1:250,000.

Brabb, E. E., and Grant, R. E., 1971, Stratigraphy and paleontology of a revised type section for the Tahkandit Limestone (Permian) in east-central Alaska: U.S. Geol. Survey Prof. Paper 703, 26 p.

Brew, D. A., 1968, The role of volcanism in post-Carboniferous tectonics of southeastern Alaska and nearby regions, North America : Internat. Geol. Cong., 23d, Prague 1968 , v. 2, p. $107-121$.

Brew, D. A., Loney, R. A., and Muffler, L. J. P., 1966, Tectonic history of southeastern Alaska, in A symposium on tectonic history and mineral deposits of the western Cordillera in British Columbia and neighboring parts of the United States: Canadian Inst. Mining, spec. v. no. 8, p. $149-170$.

Brooks, A. H.; 1911, The Mount McKinley region, Alaska, with descriptions of the igneous rocks and of the Bonnifield and Kantishna districts, by L. M. Prindle: U.S. Geol. Survey Prof. Paper 70, 234 p.

Brosgé, W. P., 1960, Metasedimentary rocks in the southcentral Brooks Range, Alaska, in Geological Survey research 1960: U.S. Geol. Survey Prof. Paper 400-B, p. B351-B352.

Brosgé, W. P., Brabb, E. E., and King, E. R., 1970, Geological interpretation of reconnaissance aeromagnetic survey of northeastern Alaska: U.S. Geol. Survey Bull. 1271-F, p. F1-F14.

Brosgé, W. P., Dutro, J. T., Jr., Mangus, M. D., and Reiser, H. N., 1962, Paleozoic sequence in eastern Brooks Range, Alaska: Am. Assoc. Petroleum Geologists Bull., v. 46 , no. 12 , p. 2174-2198.

Brosgé, W. P., Lanphere, M. A., Reiser, H. N., and Chapman, R. M., 1969, Probable Permian age of the Rampart Group, central Alaska: U.S. Geol. Survey Bull. 1294-B, p. B1-B18.

Brosgé, W. P., and Reiser, H. N., 1964, Geologic map and section of the Chandalar quadrangle, Alaska: U.S. Geol. Survey Misc. Geol. Inv. Map I-375, scale 1:250,000.

1965, Preliminary geologic map of the Arctic quadrangle, Alaska: U.S. Geol. Survey open-file report, scale $1: 250,000$. 
1969, Preliminary geologic map of the Coleen quadrangle, Alaska: U.S. Geol. Survey open-file report, scale $1: 250,000$.

Brosgé, W. P., Reiser, H. N., Dutro, J. T., Jr., and Churkin, Michael, Jr., 1966, Geologic map and stratigraphic sections, Porcupine River Canyon, Alaska: U.S. Geol. Survey open-file report, scale 1:63,360.

Brosgé, W. P., and Tailleur, I. L., 1970, Depositional history of northern Alaska, in Adkinson, W. L., and Brosgé, M. M., eds., Proceedings of the Geological Seminar on the North Slope of Alaska: Los Angeles, Pacific Sec., Am. Assoc. Petroleum Geologists, p. D1-D17.

Brown, J. S., 1926, The Nixon Fork country, and silver-lead prospects near Ruby [Alaska]: U.S. Geol. Survey Bull. 783-D, p. 97-150.

Buddington, A. F., and Chapin, Theodore, 1929, Geology and mineral deposits of southeastern Alaska: U.S. Geol. Survey Bull. 800, 398 p.

Bullard, Edward, Everett, J. E., and Smith, A. G., 1965, The fit of the continents around the Atlantic, in A symposium on continental drift: Royal Soc. [London] Philos. Trans., Ser. A, v. 258, no. 1088, p. 41-51.

Burk, C. A., 1965, Geology of the Alaska Peninsula-Island arc and continental margin: Geol. Soc. America Mem. 99, $250 \mathrm{p}$.

Cady, W. M., Wallace, R. E., Hoare, J. M., and Webber, E. J., 1955, The central Kuskokwim region, Alaska: U.S. Geol. Survey Prof. Paper 268, 132 p.

Cairnes, D. C., 1914a, Geological section along the YukonAlaska boundary line between Yukon and Porcupine Rivers: Geol. Soc. America Bull., v. 25, p. 179-204.

1914b, The Yukon-Alaska international boundary, between Porcupine and Yukon Rivers: Canada Geol. Survey Mem. 67, $161 \mathrm{p}$.

Campbell, R. H., 1967, Areal geology in the vicinity of the Chariot site, Lisburne Peninsula, northwestern Alaska: U.S. Geol. Survey Prof. Paper 395, 71 p.

Carey, S. W., 1955, The orocline concept in geotectonics, pt. I: Royal Soc. Tasmania Papers and Proc., v. 89, p. 255-288.

Chapman, R. M., Detterman, R. L., and Mangus, M. D., 1964, Geology of the Killik-Etivluk River region, Alaska: U.S. Geol. Survey Prof. Paper 303-F, p. 325-407.

Church, R. E., and Durfee, M. C., 1961, Geology of the Fossil Creek area, White Mountains, Alaska: Alaska Univ., College, M.S. thesis, 96 p.

Churkin, Michael, Jr., 1966, Morphology and stratigraphic range of the phyllocarid crustacean Caryocaris from Alaska and the Great Basin: Palaeontology, v. 9, pt. 3, p. 371-380.

- 1969, Paleozoic tectonic history of the Arctic Basin north of Alaska: Science, v. 165, p. 549-555.

1970, Fold belts of Alaska and Siberia and drift between North America and Asia, in Adkison, W. L., and Brosgé, M. M., eds., Proceedings of the Geological Seminar on the North Slope of Alaska: Los Angeles, Pacific Sec., Am. Assoc. Petroleum Geologists, p. G1-G14.

1972a, Silurian and Devonian stratigraphy of Alaska and the Silurian-Devonian boundary: Internat. Symposium on the Silurian-Devonian boundary and the stratigraphy of the Lower and Middle Devonian, 3d, Leningrad, U.S.S.R., 1968 (in press).

1972b, Western boundary of the North American continental plate in Asia: Geol. Soc. America Bull., v. 83, p. 1027-1036.

Churkin, Michael, Jr., and Brabb, E. E., 1965a, Ordovician, Silurian, and Devonian biostratigraphy of east-central Alaska: Am. Assoc. Petroleum Geologists Bull., v. 49, no. 2 , p. $172-185$.

1965b, Occurrence and stratigraphic significance of Oldhamia, a Cambrian trace fossil in east-central Alaska, in Geological Survey research, 1965: U.S. Geol. Survey Prof. Paper 525-D, p. D120-D124.

1967, Devonian rocks of the Yukon-Porcupine Rivers area and their tectonic relation to other Devonian sequences in Alaska, in Oswald, D. H., ed., International symposium on the Devonian system, Calgary, 1967, V. 2: Calgary, Alberta Soc. Petroleum Geologists, p. 227-258.

Churkin, Michael, Jr., and Carter, Claire, 1970, Earliest Silurian graptolites of Alaska and Nevada: U.S. Geol. Survey Prof. Paper 653, 51 p.

Churkin, Michael, Jr., Carter, Claire, and Eberlein, G. D., 1971, Graptolite succession across the Ordovician-Silurian boundary in southeastern Alaska: Geol. Soc. London Quart. Jour., v. 126, p. 319-330.

Churkin, Michael, Jr., Eberlein, G. D., Hueber, F. M., and Mamay, S. H., 1969, Lower Devonian land plants from graptolitic shale in southeastern Alaska: Palaeontology, v. 12, p. 559-573.

Churkin, Michael, Jr., Jaeger, Hermann, and Eberlein, G. D., 1970, Lower Devonian graptolites from southeastern Alaska: Lethaia, v. 3, p. 183-202.

Churkin, Michael, Jr., and Kay, Marshall, 1967, Graptolitebearing Ordovician siliceous and volcanic rocks, northern Independence Range, Nevada: Geol. Soc. America Bull., v. 78 , no. 5 , p. $651-668$.

Churkin, Michael, Jr., and Langenheim, R. L., Jr., 1960 , Silurian strata of the Klamath Mountains, California: Am. Jour. Sci., v. 258, no. 4, p. 258-273.

Coats, R. R., 1956, Geology of northern Adak Island, Alaska: U.S. Geol. Survey Bull. 1028-C, p. 45-67.

Collier, A. J., 1902, A reconnaissance of the northwestern portion of Seward Peninsula, Alaska: U.S. Geol. Survey Prof. Paper 2, $70 \mathrm{p}$.

Collier, A. J., Hess, F. L., Smith, P. S., and Brooks, A. H., 1908, The gold placers of parts of Seward Peninsula, Alaska, including the Nome, Council, Kougarok, Port Clarence, and Goodhope precincts: U.S. Geol. Survey Bull. 328, 343 p.

Collins, F. R., 1958, Test wells, Topagoruk area, Alaska: U.S. Geol. Survey Prof. Paper 305-D, p. 265-316.

Creager, J. S., and McManus, D. A., 1965, Pleistocene drainage patterns on the floor of the Chukchi Sea: Marine Geology, v. 3, no. 4, p. 279-290.

Danner, W. R., 1966, Limestone resources of western Washington: Washington Div. Mines and Geology Bull. 52, $474 \mathrm{p}$.

Demenitskaya, R. M., and Karasik, A. M., 1969, The active rift system of the Arctic Ocean: Tectonophysics, v. 8, p. $345-351$. 
Detterman, R. L., 1970, Sedimentary history of the Sadlerochit and Shublik Formations in northeastern Alaska, in Adkison, W. L., and Brosgé, M. M., eds., Proceedings of the Geological Seminar on the North Slope of Alaska: Los Angeles, Pacific Sec., Am. Assoc. Petroleum Geologists, p. 01-013.

Dietz, R. S., and Holden, J. C., 1970, Reconstruction of Pangaea; Breakup and dispersion of continents, Permian to present: Jour. Geophys. Research, v. 75, p. 4939-4956.

Dobretsov, N. L., Reverdatto, V. V., Sobolev, V. S., Sobolev, N. V., Ushakova, E. N., and Khlestov, V. V., 1966, Karta metamorficheskikh Fatziy SSSR [Metamorphic facies map of the USSR]: Ministerstvo geologii SSSR, scale $1: 7,500,000$.

Douglas, R. J. W., Norris, D. K., Thorsteinsson, Raymond, and Tozer, E. T., 1963, Geology and petroleum potentialities of northern Canada: Canada Geol. Survey Paper 63-31, $28 \mathrm{p}$.

Dutro, J. T., Jr., 1956, Annotated bibliography of Alaskan Paleozoic paleontology: U.S. Geol. Survey Bull. 1021-H, p. 253-287.

1970, Pre-Carboniferous carbonate rocks, northeastern Alaska, in Adkinson, W. L., and Brosgé, M. M., eds., Proceedings of the Geological Seminar on the North Slope of Alaska: Los Angeles, Pacific Sec., Am. Assoc. Petroleum Geologists, p. M1-M7.

Dutro, J. T., Jr., and Douglass, R. C., 1961, Pennylvanian rocks in southeastern Alaska, in Short papers in the geologic and hydrologic sciences: U.S. Geol. Survey Prof. Paper 424-B, p. B239-B241.

Dutro, J. T., Jr., and Payne, T. G., 1957, Geologic map of Alaska: U.S. Geol. Survey, scale 1:2,600,000.

Eakin, H. M., 1918, The Cosna-Nowitna region, Alaska: U.S. Geol. Survey Bull. 667, 54 p.

Eardley, A. J., 1961, History of geologic thought on the origin of the Arctic Basin, V. 1: Toronto, Ontario, Univ. Toronto Press, p. 607-621.

Eberlein, G. D., and Churkin, Michael, Jr., 1970, Paleozoic stratigraphy in the northwest coastal area of Prince of Wales Island, southeastern Alaska: U.S. Geol. Survey Bull. 1284, 67 p.

Egiazarov, B. Kh., and others, 1965, Geologiya i poleznye iskopaemye Koryakskogo nagor'ya [Geology and mineral resources of the Koryak Upland]: Trudy Nauchno-Issled. Inst. Geol. Arktiki, Leningrad, v. 148, 342 p.

Forbes, R. B., Pilkington, H. D., and Hawkins, D. B., 1968, Gold gradients and anomalies in the Pedro Dome-Cleary Summit area, Fairbanks district, Alaska: U.S. Geol. Survey open-file report, $43 \mathrm{p}$.

Foster, H. L., 1969, Reconnaissance geology of the Eagle A-1 and A-2 quadrangles, Alaska: U.S. Geol. Survey Bull. 1271-G, p. G1-G30.

Fostex, R. L., 1967, Tectonic inclusions from a serpentinite, east-central Alaska, in Geological Survey research 1967: U.S. Geol. Survey Prof. Paper 575-D, p. D120-D122.

Friend, P. F., 1967, The growth of the north Atlantic Ocean by the spreading of its floor: Polar Rec., v. 13, p. 579588.

Gabrielse, Hubert, 1967, Tectonic evolution of the northern Canadian Cordillera: Canadian Jour. Earth Sci., v. 4, no. 2, p. 271-298.
Gabrielse, Hubert, and Wheeler, J. 0., 1961, Tectonic framework of southern Yukon and northwestern British Columbia: Canada Geol. Survey Paper 60-24, 37 p.

Gates, G. O., and Gryc, George, 1963, Structure and tectonic history of Alaska, in Childs, O. E., and Beebe, B. W., eds., The backbone of the Americas-tectonic history from pole to pole, a symposium: Am. Assoc. Petroleum Geologists Mem. 2, p. 264-277.

Gnibidenko, G. S., 1969, Metamorficheskie kompleksy v stryktyrakh severozapadnogo sektora tikhookeanskogo poyasa [Metamorphic complexes in the structures of the northwestern sector of the circumpacific belt]: Akad. Nauk, SSSR Sibersk. Otdeleniye, Nauka, Moscow, 134 p.

Grantz, Arthur, 1966, Strike-slip faults in Alaska: U.S. Geol. Survey open-file report, $82 \mathrm{p}$.

1968, Strike-slip faults in Alaska [abs.]: Geol. Soc. America and Assoc. Soc. Ann. Mtg., Mexico City 1968, Program, p. 117.

Grantz, Arthur, Wolf, S. C., Breslau, Lloyd, Johnson, T. C., and Hanna, W. F., 1970, Geology of the Chukchi Sea as determined by acoustic and magnetic profiling, in Adkison, W. L., and Brosgé, M. M., eds., Proceedings of the Geological Seminar on the North Slope of Alaska: Los Angeles, Pacific Sec., Am. Assoc. Petroleum Geologists, p. F1-F28.

Gryc, George, Dutro, J. T., Jr., Brosgé, W. P., Tailleur, I. L., and Churkin, Michael, Jr., 1967, Devonian of Alaska, in Oswald, D. H., ed., International symposium on the Devonian system, Calgary, 1967, V. 1: Calgary, Alberta Soc. Petroleum Geologists, p. 703-716.

Hanson, B. M., 1957, Middle Permian limestone on Pacific side of Alaska Peninsula: Am. Assoc. Petroleum Geologists Bull., v. 41, no. 10, p. 2376-2378.

Harland, W. B., 1965, Discussion on the tectonic evolution of the Arctic-North Atlantic region, in A symposium on continental drift: Royal Soc. [London] Philos. Trans., Ser. A, v. 258 , no. 1088 , p. 59-75.

Heezen, B. C., and Tharp, Marie, 1965, Tectonic fabric of the Atlantic and Indian Oceans and continental drift: Royal Soc. [London] Philos. Trans., Ser. A, v. 258, no. 1988, p. $90-106$.

Hoare, J. M., 1961, Geology and tectonic setting of lower Kuskokwim-Bristol Bay region, Alaska: Am. Assoc. Petroleum Geologists Bull., v. 45, no. 5, p. 594-611.

Hoare, J. M., and Coonrad, W. L., 1961, Geologic map of Goodnews quadrangle, Alaska: U.S. Geol. Survey Misc. Geol. Inv. Map I-339, scale 1:250,000.

Holmes, M. L., Creager, J. S., and McManus, D. A., 1968, Structure and history of the Chukchi basin [abs.]: Geol. Soc. America and Assoc. Socs. Ann. Mtg., Mexico City 1968 , p. 141.

Hopkins, D. M., ed., 1967, Bering land bridge: Stanford, Calif., Stanford Univ. Press, 495 p.

Hunkins, Kenneth, Herron, Thomas, Kutschale, Henry, and Peter, George, 1962, Geophysical studies of the Chukchi cap, Arctic Ocean: Jour. Geophys. Research, v. 67, no. 1, p. 235-247.

Irwin, W. P., 1966, Geology of the Klamath Mountains province, in Bailey, E. H., ed., Geology of northern California: California Div. Mines and Geology Bull. 190, p. 19-38. 
Jackson, D. E., and Lenz, A. C., 1962, Zonation of Ordovician and Silurian graptolites of northern Yukon, Canada: Am. Assoc. Petroleum Geologists Bull., v. 46, no. 1, p. $30-45$.

Jeletzky, J. A., 1962, Pre-Cretaceous Richardson Mountains trough-its place in the tectonic framework of Arctic Canada and its bearing on some geosynclinal concepts: Royal Soc. Canada Trans., 3d ser., v. 56, sec. 3, pt. 1, p. 55-84.

Johnson, G. L., and Heezen, B. C., 1967, Morphology and evolution of the Norwegian-Greenland Sea: Deep-Sea Research, v. 14, p. 755-771.

Kay, Marshall, 1947, North American geosynclines: Geol. Soc. America Mem. 48, 143 p.

Kindle, E. M., 1908, Geologic reconnaissance of the Porcupine Valley, Alaska: Geol. Soc. America Bull., v. 19, p. 315338.

King, P, B., compiler, 1969, Tectonic map of North America: U.S. Geol. Survey, scale 1:5,000,000.

Kirk, Edwin, 1918, Paleozoic glaciation in southeastern Alaska: Am. Jour. Sci., 4th Sec., v. 46, p. 511-515.

1927, Pycnodesma, a new molluscan genus from the Silurian of Alaska: U.S. Natl. Mus. Proc., v. 71, art. 20, 9 p.

Kirk, Edwin, and Amsden, T. W., 1952, Upper Silurian brachiopods from southeastern Alaska: U.S. Geol. Survey Prof. Paper 233-C, p. 53-66.

Kobayashi, Teiichi, 1935, The Briscoia fauna of the late Upper Cambrian in Alaska, with descriptions of a few Upper Cambrian trilobites from Montana and Nevada: Japanese Jour. Geology and Geography, v. 12, nos. 3-4, p. 39-57.

Krasniy, L. I., ed., 1966, Geologicheskoe stroenie Severozapadnoi chasti tikhookeanskogo podvizhnogo poyasa [Geological structure of the northwestern part of the Pacific mobile belt]: Ministerstvo geologii SSSR, Vses. Nauchino-issled. Geol. Inst., Nedra, Moscow, 516 p.

Lanphere, M. A., 1965, Age of Ordovician and Devonian mafic rocks in northern Alaska, in Geological Survey research 1965: U.S. Geol. Survey Prof. Paper 525-A, p. A101-A102.

Lanphere, M. A., Loney, R. A., and Brew, D. A., 1965, Potassium-argon ages of some plutonic rocks, Tenakee area, Chichagof Island, southeastern Alaska, in Geological Survey research 1965: U.S. Geol. Survey Prof. Paper 525-B, p. B108-B111.

Lanphere, M. A., MacKevett, E. M., Jr., and Stern, T. W., 1964, Potassium-argon and lead-alpha ages of plutonic rocks, Bokan Mountain area, Alaska: Science, v. 145, no. 3633 , p. $705-707$.

Larson, R., Menard, H. W., and Smith, S., 1968, Gulf of California: a result of ocean floor spreading and transform faulting: Science, v. 161, p. 781-784.

Lathram, E. H., 1964, Apparent right-lateral separation on Chatham Strait fault, southeastern Alaska: Geol. Soc. America Bull., v. 75, no. 3, p. 249-251.

1965, Preliminary geologic map of northern Alaska: U.S. Geol. Survey open-file map, scale 1:1,000,000.

Lathram, E. H., Loney, R. A., Condon, W. H., and Berg, H. C., 1959, Progress map of the geology of the Juneau quadrangle, Alaska: U.S. Geol. Survey Misc. Geol. Inv. Map I-303, scale $1: 250,000$.

Lazareva, A. P., and Misharina, L. A., 1965, Stresses in earthquake foci in the Arctic seismic belt: Akad. Nauk SSSR Isv., Physics of the Solid Earth (in translation) 1965 , no. 2 , p. 84-87.

Le Pichon, Xavier, 1968, Sea-floor spreading and continental drift: Jour. Geophys. Research, v. 73, no. 12, p. 36613697.

Loney, R. A., 1964, Stratigraphy and petrography of the Pybus-Gambier area, Admiralty Island, Alaska: U.S. Geol. Survey Bull. 1178, 103 p.

Loney, R. A., Berg, H. C., Pomeroy, J. S., and Brew, D. A., 1963, Reconnaisance geologic map of Chichagof Island and northwestern Baranof Island, Alaska: U.S. Geol. Survey Misc. Geol. Inv. Map I-388, with text, scale $1: 250,000$.

Loney, R. A., Brew, D. A., and Lanphere, M. A., 1967, PostPaleozoic radiometric ages and their relevance to fault movements, northern southeastern Alaska: Geol. Soc. America Bull., v. 78, p. 511-526.

Loney, R. A., Condon, W. H., and Dutro, J. T., Jr., 1963, Geology of the Freshwater Bay area, Chichagof Island, Alaska: U.S. Geol. Survey Bull. 1108-C, p. C1-C54.

Mamet, B. L., and Skipp, Betty, 1972, Preliminary correlations of Lower Carboniferous strata in North American Cordillera: Cong. Carboniferous Stratigraphy and Geology, 6th, Sheffield, England 1967, Proc. (in press).

Martin, L. J., 1961, Tectonic framework of northern Canada, in Raasch, G. O., ed., Geology of the Arctic, V. 1: Toronto, Ontario, Univ. Toronto Press, p. 442-457.

Mendenhall, W. C., 1905, Geology of the central Copper River region, Alaska: U.S. Geol. Survey Prof. Paper 41, $133 \mathrm{p}$.

Mertie, J. B., Jr., 1930a, Geology of the Eagle-Circle district, Alaska: U.S. Geol. Survey Bull. 816, 168 p.

1930b, Mountain building in Alaska: Am. Jour. Sci., 5th ser., v. 20, p. 101-124.

1933, The Tatonduk-Nation district: U.S. Geol. Survey Bull. 836-E, p. 347-443.

1937a, The Kaiyuh Hills: U.S. Geol. Survey Bull. 868-D, p. $145-178$.

1937b, The Yukon-Tanana region, Alaska: U.S. Geol. Survey Bull. 872, 276 p. 1938, The Nushagak district, Alaska: U.S. Geol. Bull. 903, $96 \mathrm{p}$.

Miller, T. P., 1972, Potassium-rich alkaline intrusive rocks of western Alaska: Geol. Soc. America Bull., v. 83, p. 2111-2128.

Moffit, F. H., 1913, Geology of the Nome and Grand Central quadrangles, Alaska: U.S. Geol. Survey Bull. 533, 140 p.

- 1938, Geology of the Chitina Valley and adjacent area, Alaska: U.S. Geol. Survey Bull. 894, 137 p.

1954, Geology of the eastern part of the Alaska Range and adjacent area: U.S. Geol. Survey Bull. 989-D, p. 63-218.

Morgan, W. J., 1968, Rises, trenches, great faults and crustal blocks: Jour. Geophys. Research, v. 73, no. 6, 1959-1982. 
Muffler, L. J. P., 1967, Stratigraphy of the Keku Islets and neighboring parts of Kuiu and Kupreanof Islands, southeastern Alaska: U.S. Geol. Survey Bull. 1241-C, p. C1-C52.

Nikolaevskiy, A. A., 1964, Sovremyenyi relef poverkhonsti mohorovichicha po geofisicheskim dannym [Present-day relief along the Mohorovicic discontinuity based on geophysical data], in Tektonika i glubinnoe stroenie severovostoka SSSR: Akad. Nauk SSSR Sibirsk. Otdeleniye Severo-Vostoch. Kompleks. Nauchno-Issled. Inst. Trudy, no. 11, p. 131-149.

Norford, B. S., 1964, Reconnaissance of the Ordovician and Silurian rocks of northern Yukon Territory: Canada Geol. Survey Paper 63-39, 139 p.

Obradovich, J. D., and Peterman, Z. E., 1968, Geochronology of the Belt Series, Montana: Canadian Jour. Earth Sci., v. 5, p. 737-747.

Oliver, J. E., Ewing, W. M., and Press, Frank, 1955, Crustal structure of the Arctic regions from the $I_{g}$ phase: Geol. Soc. America Bull., v. 66, no. 9, p. 1063-1074.

Ostenso, N. A., 1968a, Geophysical studies in the Greenland Sea: Geol. Soc. America Bull., v. 79, no. 1, p. 107-132.

1968b, A gravity survey of the Chukchi Sea region, and its bearing on westward extension of structures in northern Alaska: Geol. Soc. America Bull., v. 79, p. 241-254.

Ovenshine, A. T., Eberlein, G. D., and Churkin, Michael, Jr., 1969, Paleotectonic significance of Silurian-Devonian clastic wedge, southeastern Alaska [abs.]: Geol. Soc. America, Cordilleran Sec., Program, p. 50.

Ovenshine, A. T., and Webster, G. D., 1970, Age and stratigraphy of the Heceta Limestone in northern Sea Otter Sound, southeastern Alaska, in Geological Survey research 1970: U.S. Geol. Survey Prof. Paper 700-C, p. C170-C174.

Palmer, A. R., 1968, Cambrian trilobites of east-central Alaska: U.S. Geol. Survey Prof. Paper 559-B, p. B1B115.

Patton, W. W., Jr., 1957, A new upper Paleozoic formation, central Brooks Range, Alaska: U.S. Geol. Survey Prof. Paper 303-B, p. 41-45.

Patton, W. W., Jr., and Dutro, J. T., Jr., 1969, Preliminary report on the Paleozoic and Mesozoic sedimentary sequence on St. Lawrence Island, Alaska: U.S. Geol. Survey Prof. Paper 650-D, p. D138-D143.

Patton, W. W., Jr., and Hoare, J. M., 1968, The Kaltag fault, west-central Alaska, in Geological Survey research 1968: U.S. Geol. Survey Prof. Paper 600-D, p. D147-D153.

Patton, W. W., Jr., and Tailleur, I. L., 1964, Geology of the Killik-Itkillik region, Alaska: U.S. Geol. Survey Prof. Paper 303-G, p. 409-500.

Payne, T. G., 1955, compiler, Mesozoic and Cenozoic tectonic elements of Alaska: U.S. Geol. Survey Misc. Geol. Inv. Map I-84, scale 1:5,000,000.

Payne, T. G., and others, 1951, Geology of the Arctic slope of Alaska: U.S. Geol. Survey Oil and Gas Inv. Map OM126 , scale $1: 1,000,000$ [1952].

Peive, A. V., 1969, Okeanicheskaya kora geologicheskogo proshologo [Oceanic crust in the geologic past]: Geotektonika, no. 4, p. 5-23.
Petocz, R. G., 1970, Biostratigraphy and Lower Permian fusulinidae of the upper Delta River area, east-central Alaska Range: Geol. Soc. America Spec. Paper 130, 94 p.

Péwé, T. L., Wahrhaftig, Clyde, and Weber, F. R., 1966, Geologic map of the Fairbanks quadrangle, Alaska: U.S. Geol. Survey Misc. Geol. Inv. Map I-455, scale 1:250,000.

Pitman, W. C., III, and Hayes, D. E., 1968, Sea-floor spreading in the Gulf of Alaska: Jour. Geophys. Research, v. 73 , no. 20, p. 6571-6580.

Plafker, George, 1969, Tectonics of the March 27, 1964, Alaska earthquake: U.S. Geol. Survey Prof. Paper 543-I, $74 \mathrm{p}$.

Porter, S. C., 1966, Stratigraphy and deformation of Paleozoic section at Anaktuvuk Pass, central Brooks Range, Alaska: Am. Assoc. Petroleum Geologists Bull., v. 50, p. 952-980.

Reed, B. L., 1968, Geology of the Lake Peters area, northeastern Brooks Range, Alaska: U.S. Geol. Survey Bull. 1236, $132 \mathrm{p}$.

Reed, B. L., and Lanphere, M. A., 1969, Age and chemistry of Mesozoic and Tertiary plutonic rocks in south-central Alaska: Geol. Soc. America Bull., v. 80, p. 23-44.

Reiser, H. N., 1970, Northeastern Brooks Range-a surface expression of the Prudhoe Bay section, in Adkison, W. L., and Brosgé, M. M., eds., Proceedings of the Geological Seminar on the North Slope of Alaska: Los Angeles, Pacific Sec., Am. Assoc. Petroleum Geologists, p. K1K10.

Rezanov, I. A., 1964, Voprosy noveishei tektoniki SeveroVostoka SSSR [Questions of the modern tectonics of North-East U.S.S.R.] : Akad. Nauk, SSSR, Moscow, 148 p.

Rickwood, F. K., 1970, The Prudhoe Bay field, in Adkison, W. L., and Brosgé, M. M., eds., Proceedings of the Geological Seminar on the North Slope of Alaska: Los Angeles, Pacific Sec., Am. Assoc. Petroleum Geologists, p. L1-L11.

Roberts, R. J., Hotz, P. E., Gilluly, James, and Ferguson, H. G., 1958, Paleozoic rocks of north-central Nevada : Am. Assoc. Petroleum Geologists Bull., v. 42, no. 12, p. 2813-2857.

Roddick, J. A., 1967, Tintina Trench: Jour. Geology, v. 75, no. 1, p. 23-32.

Ross, C. P., 1933, Mineral deposits near the West Fork of the Chulitna River, Alaska: U.S. Geol. Survey Bull. 849-E, p. 289-333.

Rossman, D. L., 1963, Geology of the eastern part of the Mount Fairweather quadrangle, Glacier Bay, Alaska: U.S. Geol. Survey Bull. 1121-K, p. K1-K57.

Rowett, C. L., 1969, Upper Paleozoic stratigraphy and corals from east-central Alaska Range, Alaska: Arctic Inst. North America Tech. Paper no. 23, 120 p.

Sable, E. G., 1965, Geology of the Romanzof Mountains, Brooks Range, northeastern Alaska: U.S. Geol. Survey open-file report, $218 \mathrm{p}$.

Sable, E. G., and Dutro, J. T., Jr., 1961, New Devonian and Mississippian formations in De Long Mountains, northern Alaska: Am. Assoc. Petroleum Geologists Bull., v. 45 , no. 5 , p. $585-593$.

Sainsbury, C. L., 1961, Geology of part of the Craig C-2 quadrangle and adjoining areas, Prince of Wales Island, 
southeastern Alaska: U.S. Geol. Survey Bull. 1058-H, p. 299-362.

1965, Previously undescribed Middle(?) Ordovician, Devonian (?), and Cretaceous (?) rocks, White Mountain area, near McGrath, Alaska, in Geological Survey research 1965: U.S. Geol. Survey Prof. Paper 525-C, p. C91-C95.

-1969a, Geology and ore deposits of the central York Mountains, western Seward Peninsula, Alaska: U.S. Geol. Survey Bull. 1287, 101 p.

1969b, The A. J. Collier thrust belt of the Seward Peninsula, Alaska: Geol. Soc. America Bull., v. 80, p. 2595-2596.

Sainsbury, C. L., Dutro, J. T., Jr., and Churkin, Michael, Jr., 1971, The Ordovician-Silurian boundary in the York Mountains, western Seward Peninsula, Alaska, in U.S. Geological Survey research 1971: U.S. Geol. Survey Prof. Paper 750-C, p. C52-C57.

St. Amand, Pierre, 1957, Geological and geophysical synthesis of the tectonics of portions of British Columbia, the Yukon Territory, and Alaska: Geol. Soc. America Bull., v. 68, no. 10, p. 1343-1370.

Scheidegger, A. E., 1966, Tectonics of the Arctic seismic belt in the light of fault-plane solutions of earthquakes: Seismol. Soc. America Bull., v. 56, p. 241-245.

Scholl, D. W., Buffington, E. C., and Hopkins, D. M., 1966, Exposure of basement rock on the continental slope of the Bering Sea: Science, v. 153, p. 992-994.

Scholl, D. W., Greene, H. G., Marlow, M. S., 1970, Eocene age of the Adak "Paleozoic(?)" rocks, Aleutian Islands, Alaska: Geol. Soc. America Bull., v. 81, p. 3583-3592.

Scholl, D. W., Marlow, M. S., Creager, J. S., Holmes, M. L., Wolf, S. C., and Cooper, A. K., 1970, A search for the seaward extension of the Kaltag fault beneath the Bering Sea: Geol. Soc. America, Abstracts with Programs, v. 2, p. 141-142.

Schuchert, Charles, 1910, Paleogeography of North America: Geol. Soc. America Bull., v. 20, p. 427-606.

Shatskiy, N. S., 1935, O tektonike Arktiki [On the tectonics of the Arctic], in U.S.S.R. Glavnoe upravlenie Severnogo morskogo puti, Geologo-Razvedochnaia Konferentisiia, 1st, Moskva, 1935: Geologiia i poleznye iskopaemye Sovera SSSR Trudy, v. 1, Geologiia, p. 149-168.

Smith, J. G., and MacKevett, E. M., Jr., 1970, Skolai Group in the McCarthy $\mathrm{B}-4, \mathrm{C}-4$, and $\mathrm{C}-5$ quadrangles, Wrangell Mountains, Alaska: U.S. Geol. Survey Bull. 1274-Q, $26 \mathrm{p}$.

Smith, P. S., 1939, Areal geology of Alaska: U.S. Geol. Survey Prof. Paper 192, $100 \mathrm{p}$.

Smith, P. S., and Eakin, H. M., 1911, A geologic reconnaissance in southeastern Seward Peninsula and the Norton Bay-Nulato region, Alaska: U.S. Geol. Survey Bull. 449, $146 \mathrm{p}$.

Spurr, J. E., 1898, Geology of the Yukon gold district, Alaska: U.S. Geol. Survey 18th Ann. Rept., pt. 3, p. 87-392.

Steidtmann, Edward, and Cathcart, S. H., 1922, Geology of the York tin deposits, Alaska: U.S. Geol. Survey Bull. $733,130 \mathrm{p}$.

Stoneley, Robert, 1967, The structural development of the Gulf of Alaska sedimentary province in southern Alaska:
Geol. Soc. London Quart. Jour., v. 123, no. 489, pt. 1, p. 25-57.

Sykes, L. R., 1965, The seismicity of the Arctic: Seismol. Soc. America Bull., v. 55, no. 2, p. 501-518.

Tailleur, I. L., 1969, Speculations on North Slope geology: Oil and Gas Jour., v. 67, no. 38, p. 215-226.

Tailleur, I. L., and Brosgé, W. P., 1970, Tectonic history of northern Alaska, in Adkison, W. L., and Brosgé, M. M., Proceedings of the Geological Seminar on the North Slope of Alaska: Los Angeles, Pacific Sec., Am. Assoc. Petroleum Geologists, p. E1-E19.

Tailleur, I. L., Brosgé, W. P., and Reiser, H. N., 1967, Palinspastic analysis of Devonian rocks in northwestern Alaska, in Oswald, D. H., ed., International symposium on the Devonian system, Calgary, 1967, V. 2: Calgary, Alberta Soc. Petroleum Geologists, p. 1345-1361.

Tailleur, I. L., Kent, B. H., Jr., and Reiser, H. N., 1966, Outcrop/geologic maps of the Nuka-Etivluk region, northern Alaska: U.S. Geol. Survey open-file maps, scale $1: 63,360$.

Tailleur, I. L., and Sable, E. G., 1963, Nuka Formation of late Mississippian to late Permian age, new formation in northern Alaska: Am. Assoc. Petroleum Geologists Bull., v. 47 , no. 4 , p. 632-642.

Tailleur, I. L., and Snelson, Sigmund, 1968, Large-scale thrusting in northwestern Alaska possibly related to rifting of the Arctic Ocean [abs.]: Geol. Soc. America and Assoc. Socs. Ann. Mtg., Tucson, Ariz., 1968, Program, p. 120.

Thorsteinsson, Raymond, and Tozer, E. T., 1960, Summary account of structural history of the Canadian Arctic Archipelago since Precambrian time: Canada Geol. Survey Paper 60-7, 25 p.

Tilman, S. M., 1962, Tektonika i istoriya razvitiya severovostochnogo Prikolym'ya [Tectonics and the history of the development of the region northeast of Kolyma]: Trudy SVKNII (Sev. Vost. Komplek. Nauchno-Issled. Inst.), Magadan, No. 1, $190 \mathrm{p}$.

Trettin, H. P., 1967, Devonian of the Franklinian eugeosyncline, in Oswald, D. H., ed., International symposium on the Devonian system, Calgary, 1967, V. 1: Calgary, Alberta Soc. Petroleum Geologists, p. 693-701.

1969, A Paleozoic-Tertiary fold belt in northernmost Ellesmere Island aligned with the Lomonosov Ridge: Geol. Soc. America Bull., v. 80, p. 143-148.

Twenhofel, W. S., and Sainsbury, C. L., 1958, Fault patterns in southeastern Alaska: Geol. Soc. America Bull., v. 69, no. 11 , p. 1431-1442.

Vine, F. J., 1966, Spreading of the ocean floor-new evidence: Science, v. 154, p. 1405-1415.

Vogt, P. R., and Ostenso, N. A., 1970, Magnetic and gravity profiles across the Alpha cordillera and their relation to arctic sea-floor spreading: Jour. Geophys. Research, v. 75 , no. 26, p. $4925-4937$.

Vogt, P. R., Ostenso, N. A., and Johnson, G. L., 1970, Magnetic and bathymetric data bearing on sea-floor spreading north of Iceland: Jour. Geophys. Research, v. 75, p. 903-920.

Wahrhaftig, Clyde, 1968, Schists of the central Alaska Range: U.S. Geol. Survey Bull. 1254-E, p. E1-E22. 
Wanless, R. D., Stevens, R. D., Lachance, G. R., and Rimsaite, R. Y. H., 1965, Age determinations and geologic studies, Part 1, Isotopic ages, Report 5: Canada Geol. Survey Paper 64-17, $126 \mathrm{p}$.

Wasserburg, G. J., Eberlein, G. D., and Lanphere, M. A., 1963, Age of the Birch Creek Schist and some batholithic intrusions in Alaska [abs.]: Geol. Soc. America Spec. Paper 73, p. 258-259.

Wilson, J. T., 1963, Hypothesis of earth's behavior: Nature, v. 198, p. 925-929.

Wold, R. J., and Ostenso, N. A., 1972, Aeromagnetic evidence for origin of Arctic Ocean basin: Internat. Symposium Arctic Geology, 2d, Pacific Sec., Am. Assoc. Petroleum Geologists (in press).

Wollard, G. P., Ostenso, N. A., Thiel, E., and Bonini, W. E.,
1960, Gravity anomalies, crustal structure, and geology in Alaska: Jour. Geophys. Research, v. 65, no. 3, p. 10211037.

Yanshin, A. L., ed., 1966, Tectonic map of Eurasia: Acad. Sci. USSR, Geol. Inst., scale 1:5,000,000.

Yates, R. G., Becraft, G. E., Campbell, A. B., and Pearson, R. C., 1966, Tectonic framework of northeastern Washington, northern Idaho, and northwestern Montana, in A symposium on the tectonic history and mineral deposits of the western Cordillera, Vancouver, B. C., 1964: Canadian Inst. Mining and Metallurgy, Spec. V. 8, p. 47-59.

Ziegler, P. A., 1969, The development of sedimentary basins in western and Arctic Canada: Alberta, Canada, Alberta Soc. Petroleum Geologists, 89 p. 


\section{N D E X}

[Italic page numbers indicate major references]

A

Acknowledeement

Adak Irland

Adams Arcillite

te --on-

Alaske Rance, Cambrian rocks

Devonian limestone

Misaissippian rocks

Paleosoic sedimentation

Pennsylvanian rocks

Permian reference fosails

Perminn rociks -

A!dan Shield, Siberia - ...............

Aleutian volcanic arc, relation to orogeny

Alexander Archipelago

Appalachian zeosyncline

Arctic Ocean, sea-floor apreading -...-

Atlantic Ocean, sea-floor spreading -.-

Barrow arch

Bay of Pillers Formation

Belt Supergroup - 6,

Bering Shelf - 39

Bering Straita, sea-level changes -...- 18

Bibliography -..- 55

Birch Creek Schist _......... 7, 35, 44,47

British Mountains -..-_-_-_-_-_- 88,44

Brooks geosyncline -

Brooks Rangre, circumarctic foldbelt -- 44

Devonien and Missisaippian rocks -- 86

Mississippian rocks _._-_-_-_-_-- 27

Pennaylvanian fossils -..---_-.- 30

Permian rocks --

tectonic events

\section{C}

Calico Bluf Formation -

Cambrian rocks Canada Basin _...

Canadian Aretic Islanda _..._...- 88

Cape Dezhneva ares, comparison to Seward Peninsula -..-- 60

Cape Kekurnoi area, Permian rocks _-

Cape Prince of Wales Carboniferous rocks Caryocario -..._. 18

Cascade Mountains - 86

Cenoyoic tectonic eventw -

Chatham Strait fault -

Cherakiy recosmeline -

Cherskiy Mountain aystem, U.S.S.R._-- 62, 64

Chichnzof Islend -

Chitina Valley -

Chusach Mountains -

Chukchi Cap -

Chukotke

Chukotka foldbelt, Siberia

44
Pace

Chukotsk Peninsula, rocks similar to Seward Peninsule rocks.. 9, 14, 50

Circle -...

Circle mining distriet

Circle Volcanics -

Circumarctic foldbelt -

Circum-Canade Basin geosyncline -.-.- 88

Circumpacific foldbelt _.

Colville basin

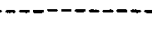

17

Continental drift

Copper River valley

Cordilleran foldbelt

Cordilleran reosyneline

Correlation, Alaka, Canada, and Siberia

Craig-Klawak are

Crasy Mounteins

\section{D}

Dadine Sehint 29 Dating, isotope --.- 7, 9, 14, 17, 34, 36, 44, 60 Dave Lord Ridge -_- 39 DeLong Mountains _........ 35

Delta River area -.......-

Dens:i fault system -

Deseon Formation -.._._._._.- 14

Devonian rocks, stratigraphy _...-_ 18, 18 tectonics -

E

Eagle area, Paleozoic sedimentation -- 37 Ellemere Island -

Eurasia Basin _.

Eurasian plate

Fairbanks mining distriet Faults

Foldbelts

Ford toke shale

Fortymile mining district

Fossil Creek Volcanies -

Fossils, Adak Island

Adams Argillite

Birch Creek Schist

Carboniferous rocks

Goodnews Bay district ..........

Jones Ridge area

Karheen Formation -.........--

Nahoni Range-Blackstone

$$
\text { River area - - }
$$

Neruokpuk Formation -..--.---

Permian reference, Alaskn Range.

Permian rocks

Rambart Group

Road River Formation

Skajit Limestone -

Tindir Group

Totalanika Schist
Franklinian geosyncline Page

Frazer eugeosynclinal belt _......... 87

$\mathbf{G}$

Gakkel Ridge Gemuk Group -

Geologic conditions, Mesozoic _...-- 40

Glaciation _... 36

Glecier Bay - $\quad 86$

Goodnews Bay district _.

Great Basin -... 37

$\mathbf{H}$

Heceta Limestone -_-_-_-_-_-_- 18, 19

Hillard Limestone _..._..... 10

Holitna Group -

Hunt Fork Shale

I

Iliamna Lake-Kamishak Bay area -.-- 33 Inoceramus - -

Introduction Isotope dating -... $7,9,14,17,34,36,44,50$

$\mathbf{J}$

Jones Ridge Limestone -

$\mathbf{R}$

Kaltag fault

Kamchatke -

Kanayut Formation -

Karheen Formation

Kayat Shale -_-_-_-__-_-_-_-_-_- 27

Keku Strait area

Kenai Peninsula -

Kigluaik Group -

Kigluaik Mountains _- 50

Klamath Mountains _....... 36, 37

Klutine Group - 29

Kodiak Island -

Kolymski massif, Siberia _._._._._ 50, 51, 54

Koryak Mountains, Northeast U.S.S.R. - -

Kuiu Island

Kuskokwim River region _._._._._ 37, 11

$\mathbf{L}$

Laptev Sea -

Linograptus -

Lisburne Group -

Lithology, Tindir Group _........ 6, 7

Livengood Chert 27

Lomonosov Ridge - _.._-_-_-_._-_ 52

Lower Paleozoic rocks, sedimentation.-- 10

tectonics _...... 36 


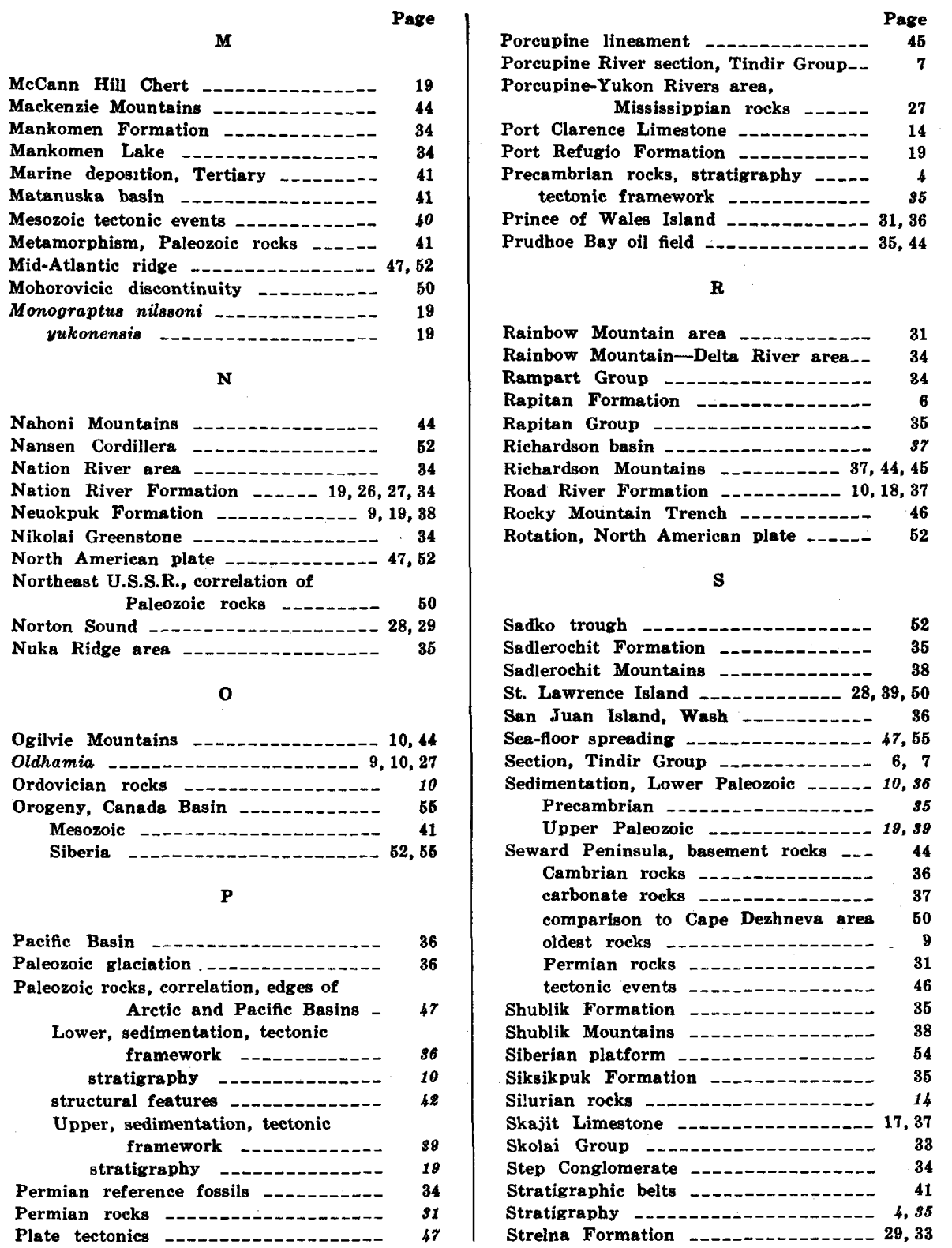

Stringocephalus

Page

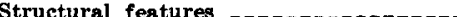

Suemez-Shelikof Island area _....... 30

Sverdrup Basin - 50

Syringopora _..._. 29

$\mathbf{T}$

Tahkandit Limestone _._.

Taimyr Peninsula

Tectonies -

Tetradium -.....- 13

Tidal Formation _.... 18

Tindir Group, correlation with other rocks - 35

Porcupine River section -

stratigraphy _._._.

Yukon River section

Tintina fault zone -

To'ovana Limestone -

Topagorup test well _._-_._-_-_-_ 19

Totatlanika Schist -

Trenches _... 46

\section{$\mathbf{U}$}

Upper Paleozoic rocks, sedimentation_- 19 tectonics

$\mathbf{v}$

Verkhoyansk Mountains $52,54,55$

$\mathbf{w}$

Wadleigh Limestone 19

Wales Group

Wernecke Mountains _-_-_._. 44

White Mountains _...... 46

Willoughby Limestone _._. 36

Windermere Series

Wrangell Island _.... $38,48,50$

Wrangell Mountains _._._._ 29, 31, 33, 39, 41

\section{$\mathbf{Y}$}

Yakutia 52,55

Yukon Flats Yukon-Kuskokwim area Yukon-Porcupine Rivers area _._._._ 39, 50

Yukon River area

Yukon shelf

Yukon-Tanana Upland -...- 27, 39, 41, 44 